\title{
Heavy Metal Tolerance in Plants: Role of Transcriptomics, Proteomics, Metabolomics, and lonomics
}

\author{
Samiksha Singh ${ }^{1}$, Parul Parihar ${ }^{1}$, Rachana Singh ${ }^{1}$, Vijay P. Singh ${ }^{2 *}$ and Sheo M. Prasad ${ }^{1 *}$ \\ ${ }^{1}$ Ranjan Plant Physiology and Biochemistry Laboratory, Department of Botany, University of Allahabad, Allahabad, India, \\ ${ }^{2}$ Department of Botany, Government Ramanuj Pratap Singhdev Post Graduate College, Sarguja University, Baikunthpur, India
}

OPEN ACCESS

Edited by:

Zuhua He,

Shanghai Institute for Biological

Sciences, China

Reviewed by:

Carla Antonio,

Instituto de Tecnologia Química e

Biológica, Portugal

Dai-Yin Chao,

Shanghai Institute of Plant Physiology

and Ecology, China

*Correspondence:

Vijay P. Singh

vijaypratap.au@gmail.com

Sheo M. Prasad

profsmprasad@gmail.com

Specialty section:

This article was submitted to

Plant Physiology,

a section of the journal

Frontiers in Plant Science

Received: 14 August 2015 Accepted: 02 December 2015

Published: 08 February 2016

Citation:

Singh S, Parihar P, Singh R, Singh VP and Prasad SM (2016) Heavy Metal

Tolerance in Plants: Role of Transcriptomics, Proteomics,

Metabolomics, and lonomics.

Front. Plant Sci. 6:1143.

doi: 10.3389/fp/s.2015.01143
Heavy metal contamination of soil and water causing toxicity/stress has become one important constraint to crop productivity and quality. This situation has further worsened by the increasing population growth and inherent food demand. It has been reported in several studies that counterbalancing toxicity due to heavy metal requires complex mechanisms at molecular, biochemical, physiological, cellular, tissue, and whole plant level, which might manifest in terms of improved crop productivity. Recent advances in various disciplines of biological sciences such as metabolomics, transcriptomics, proteomics, etc., have assisted in the characterization of metabolites, transcription factors, and stress-inducible proteins involved in heavy metal tolerance, which in turn can be utilized for generating heavy metal-tolerant crops. This review summarizes various tolerance strategies of plants under heavy metal toxicity covering the role of metabolites (metabolomics), trace elements (ionomics), transcription factors (transcriptomics), various stress-inducible proteins (proteomics) as well as the role of plant hormones. We also provide a glance of some strategies adopted by metal-accumulating plants, also known as "metallophytes."

Keywords: crop, heavy metal, ionomics, metabolomics, metallophytes, proteomics, transcriptomics, yield

\section{INTRODUCTION}

During the last few decades, increased anthropogenic activities, rapid industrialization, and modern agricultural practices have resulted in increased heavy metal contamination in the environment, which causes toxicity to the living organisms (Eapen and D'Souza, 2005; Kavamura and Esposito, 2010; Miransari, 2011). Large areas of land have been contaminated with heavy metals due to the use of pesticides, fertilizers, municipal and compost wastes, and also due to heavy metal release from smelting industries and metalliferous mines (Yang et al., 2005). Although many heavy metals occur naturally in the earth's crust at various levels, the problem arises when they are released in excess into the environment due to natural and/or anthropogenic activities. The 53 elements belonging to the d-block have been categorized as "heavy metals" based on their density $\left(>5 \mathrm{~g} / \mathrm{cm}^{3}\right)$ (Jarup, 2003). During evolution of angiosperms, only 19 elements such as $\mathrm{C}$, $\mathrm{O}, \mathrm{H}, \mathrm{Mg}, \mathrm{S}, \mathrm{N}, \mathrm{Ca}, \mathrm{P}$, and $\mathrm{K}$ (macronutrients) and $\mathrm{Cu}, \mathrm{Zn}, \mathrm{Mn}, \mathrm{Fe}, \mathrm{Mo}, \mathrm{B}, \mathrm{Ni}, \mathrm{Co}, \mathrm{Cl}$, and $\mathrm{B}$ (micronutrients) were selected for basic metabolism (Ernst, 2006). In addition, $\mathrm{Si}$ is also considered as a beneficial element, and it has been reported to be involved in the maintenance of plant structures in some plants (Epstein, 1999). Macro and micronutrients play an important role in physiological and biochemical processes of plants such as chlorophyll biosynthesis, photosynthesis, 
DNA synthesis, protein modifications, redox reactions in the chloroplast and the mitochondrion, sugar metabolism, and nitrogen fixation. For example, $\mathrm{Zn}$ is a cofactor for more than 300 enzymes and 200 transcription factors associated with the maintenance of membrane integrity, auxin metabolism, and reproduction (Marschner, 1995; Barker and Pilbeam, 2007; Briat et al., 2007; Williams and Pittman, 2010; Prasad, 2012; Ricachenevsky et al., 2013). However, at elevated concentrations, heavy metals produce severe toxicity symptoms in plants, and therefore, their uptake and utilization are tightly controlled by the plant cells (Janicka-Russak et al., 2008; Saito et al., 2010; Singh et al., 2012; Srivastava et al., 2012; DalCorso et al., 2013a; Farias et al., 2013; Fidalgo et al., 2013). Some heavy metals, such as $\mathrm{Cd}, \mathrm{Cr}, \mathrm{Pb}, \mathrm{Al}, \mathrm{Hg}$, etc., although being non-essential and without physiological function, are very toxic even at very low concentrations (Ernst et al., 2008; Janicka-Russak et al., 2008; Garzón et al., 2011; Hayat et al., 2012; Shahid et al., 2012; Chong-qing et al., 2013; Gill et al., 2013). Essential and nonessential heavy metals generally produce common toxic effects on plants, such as low biomass accumulation, chlorosis, inhibition of growth and photosynthesis, altered water balance and nutrient assimilation, and senescence, which ultimately cause plant death.

In addition to adverse impacts on plants, heavy metals pose threat to human health due to their persistence in nature. For instance, $\mathrm{Pb}$ is one of the most toxic heavy metals that has soil retention time of 150-5000 years and reported to maintain its concentration high for as long as 150 years (NandaKumar et al., 1995; Yang et al., 2005). Plants growing in heavy metalcontaminated sites generally accumulate higher amounts of heavy metals, and thus, contamination of food chain occurs. Contaminated food chain acts as a primary route for the entry of heavy metals into animal and human tissues, making them prone to several diseases that range from dermatitis to various types of cancers (McLaughlin et al., 1999). This problem might become even worse if sufficient measures are not taken at the right time. Therefore, research in this area is driven by the hope to decrease the entry of heavy metals in crop plants, thereby reducing the risk of contamination in animals and human beings.

Abiotic stresses are estimated to be the main cause for global crop yield reduction of ca. $70 \%$, and thus, are considered a great constraint to crop production (Acquaah, 2007; Jewell et al., 2010). This situation has worsened due to disturbed equilibrium between crop productivity and population growth. Therefore, it is especially important to understand plants' responses to such stressors, particularly heavy metals, in order to find new methods for improving crops quantitatively and qualitatively. Currently, studies are being performed to address the above mentioned problems and have majorly focused on "omic" tools that take into consideration of ionomics (trace elements), metabolomics (metabolome), transcriptomics (transcriptome), and proteomics (proteome). The data obtained will provide insights that might help in enhancing stress tolerance and be employed in breeding and engineering programs aiming at developing plants with new and desired agronomical traits (Lee et al., 2007; Atkinson and Urwin, 2012). In this context, this review is focused on several aspects, from plant responses to heavy metals (considering sensitive as well as metallophytes) to the role of ionomics, metabolomics, transcriptomics, and proteomics in the regulation of heavy metal tolerance (Figure 1).

\section{PLANT RESPONSES TO HEAVY METAL STRESS}

Being sessile organisms, plants cannot escape unwanted changes in the environment. Exposure to heavy metals triggers a wide range of physiological and biochemical alterations, and plants have to develop and/or adopt a series of strategies that allow them to cope with the negative consequences of heavy metal toxicity. Plants respond to external stimuli including heavy metal toxicity via several mechanisms. These include (i) sensing of external stress stimuli, (ii) signal transduction and transmission of a signal into the cell, and (iii) triggering appropriate measures to counterbalance the negative effects of stress stimuli by modulating the physiological, biochemical, and molecular status of the cell. At the whole plant level, it is difficult to measure sensing and changes in the signal transduction after exposing plants to heavy metal stress. However, monitoring early responses, such as oxidative stress, transcriptomic and proteomic changes, or accumulation of metabolites, might be useful to

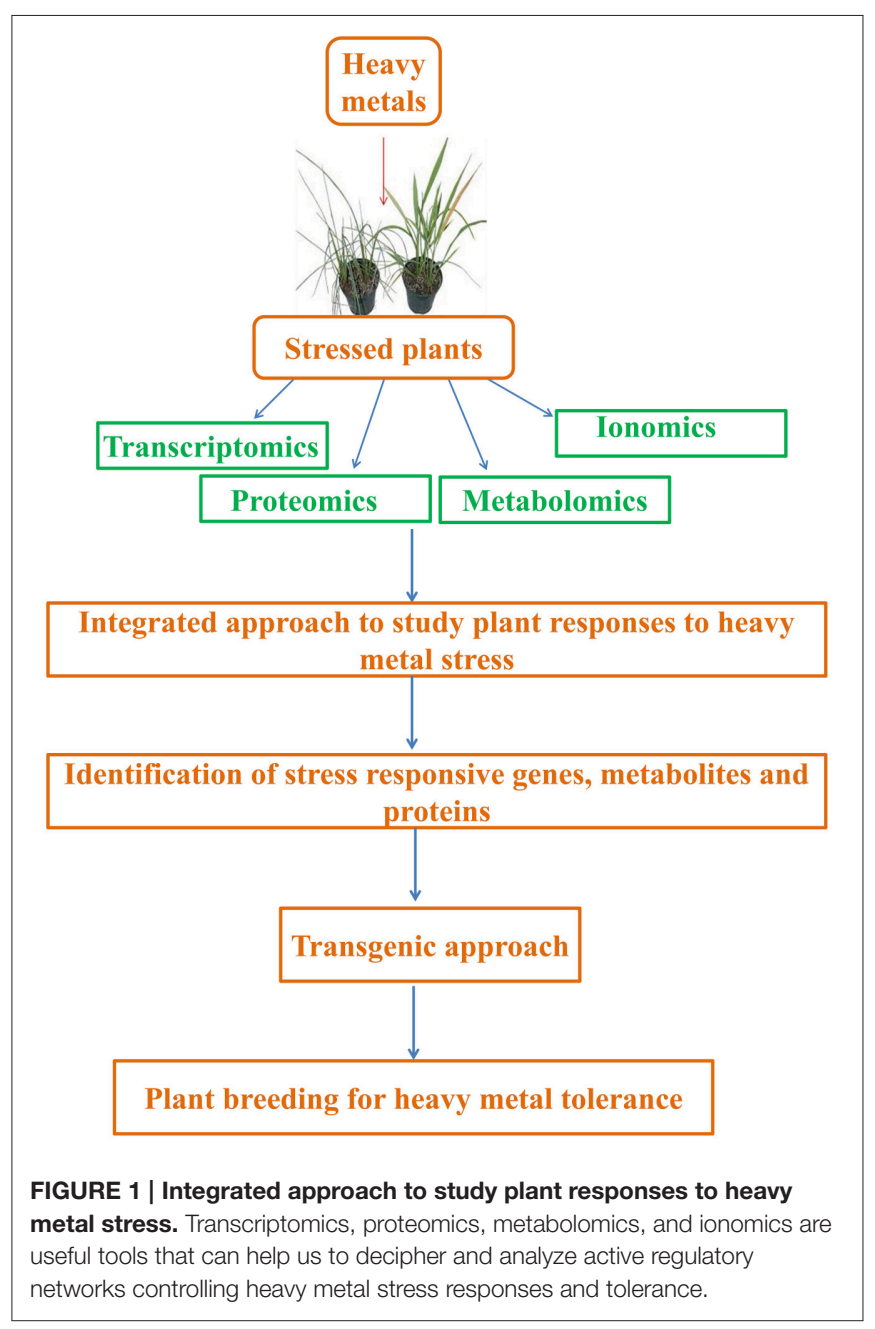


study sensing and signal transduction changes that take place after plants' exposure to stress. For instance, Tamás et al. (2010) reported that early signs of metal toxicity in barley were similar to water deficiency signs, and thus, overexpression of genes related to dehydration stress in barley was found after exposure to Cd and Hg. Similar to this, Hernandez et al. (2012) reported oxidative stress and glutathione depletion in alfalfa roots as early signs of sensing and signal transduction after exposure to heavy metals. In another study by Zhang et al. (2002), seed germination and seedling growth of wheat was found to be inhibited due to high concentration of As. Similarly, Imran et al. (2013) reported reduction in plumule and radicle length of Helainthus annuus L. seedlings when exposed to As. In addition, As has also been reported to decrease the photosynthetic pigment, damage chloroplast membrane, and decrease enzyme activity by reacting with the sulfhydryl group of proteins and also reported to alter nutrient balance and protein metabolism (Li et al., 2006; Singh et al., 2009; Ahsan et al., 2010).

Heavy metals exert toxicities in plants through four proposed mechanisms. These include (i) similarities with the nutrient cations, which result into a competition for absorption at root surface; for example, As and Cd compete with P and Zn, respectively, for their absorption; (ii) direct interaction of heavy metals with sulfhydryl group (-SH) of functional proteins, which disrupts their structure and function, and thus, renders them inactive; (iii) displacement of essential cations from specific binding sites that lead to a collapse of function; and (iv) generation of reactive oxygen species (ROS), which consequently damages the macromolecules (Sharma and Dietz, 2009; DalCorso et al., 2013a).

The roots of sessile plants are the first organ that encounters heavy metals, and thus, roots have been widely studied to assess the impact of a stressor. Plants growing on heavy metal-rich soils suffer from both decreased growth and yield (Keunen et al., 2011), indicating an implication of heavy metal toxicity in hampering the overall growth performance of the stressed plants (Kikui et al., 2005; Panda et al., 2009; Buendía-González et al., 2010; Gangwar et al., 2010, 2011; Gangwar and Singh, 2011; Eleftheriou et al., 2012; Hayat et al., 2012; Silva, 2012; Anjum et al., 2014). Root growth is a combination of cell division and elongation. In this context, a decrease in mitotic activity has been reported in several plant species after exposure to heavy metals, which consequently results into a suppressed root growth (Fontes and Cox, 1998; Doncheva et al., 2005; Sundaramoorthy et al., 2010; Hossain et al., 2012a,b; Thounaojam et al., 2012). A study by Liu et al. (1992) showed that $\mathrm{Cr}(\mathrm{VI})$ has greater toxic effect on cell division than $\mathrm{Cr}$ (III). Furthermore, Sundaramoorthy et al. (2010) have also observed that $\mathrm{Cr}(\mathrm{VI})$ caused an extension in cell cycle that leads to the inhibition in cell division, thereby reducing root growth.

Pena et al. (2012) have reported that Cd toxicity affects the cell cycle G1/S transition and progression through S phase via decreased expression of a cyclin-dependent kinase (CDK), suggesting that ROS might be involved in such alterations. Yuan et al. (2013) have reported that excess $\mathrm{Cu}$ affects both elongation and meristem zones by altering auxin distribution through PINFORMED1 (PIN1) protein, and that $\mathrm{Cu}$-mediated auxin redistribution is responsible for $\mathrm{Cu}$-mediated inhibition of primary root elongation. Similarly, Petö et al. (2011) have also demonstrated that excess $\mathrm{Cu}$ inhibits root length and alters morphology by inducing alterations in auxin levels, which antagonizes nitric oxide function. It has also been demonstrated that inhibition in root growth is accompanied by an increase in root diameter, suggesting that plant cytoskeleton might also be a target of heavy metal toxicity (Zobel et al., 2007). Therefore, these studies suggest that heavy metals might cause an inhibition in root growth that alters water balance and nutrient absorption, thereby affecting their transportation to the aboveground plant parts and thus negatively affecting shoot growth and ultimately decreasing biomass accumulation. Roots utilize several mechanisms such as synthesis and deposition of callose to reduce and/or avoid heavy metal toxicity. These mechanisms create a barrier for the entry of heavy metals and enhance plasticity of root anatomy. Apart from barricading the entry of heavy metals, roots also allow their transportation to aboveground plant parts (in the case of metallophytes or hyperaccumulator plants: plants that can grow in heavy metal-contaminated soil; Fahr et al., 2013) for sequestration into the vacuoles rendering them inactive, and thus non-reactive.

Plasma membranes serve as a highly regulated checkpoint for an entry of unwanted substances inside the cell and protect the cell from negative consequences of many stressors. It has been reported that Arabidopsis halleri and Arabidopsis arenosa were more tolerant to heavy metal stress than Arabidopsis thaliana due to the lowest membrane depolarization, indicating that rapid membrane voltage changes might be an excellent tool for monitoring the effects of heavy metal toxicity (Kenderešová et al., 2012). Once inside the cell, heavy metals alter metabolism that results into a reduction of growth and lower biomass accumulation (Nagajyoti et al., 2010). Heavy metal toxicity might also cause stunted stem and root length, and chlorosis in younger leaves that can extend to the older leaves after prolonged exposure (Israr et al., 2006; Guo et al., 2008a,b; Warne et al., 2008; Gangwar and Singh, 2011; Gangwar et al., 2011; Srivastava et al., 2012). At the cellular and molecular levels, heavy metal toxicity affects plants in many ways. For instance, it alters the key physiological and biochemical processes such as seed germination, pigment synthesis, photosynthesis, gas exchanges, respiration, inactivation and denaturation of enzymes, blocks functional groups of metabolically important molecules, hormonal balance, nutrient assimilation, protein synthesis, and DNA replication (Nagajyoti et al., 2010; Yadav, 2010; Keunen et al., 2011; He et al., 2012; Hossain et al., 2012a,b; Silva, 2012; Wani et al., 2012; Singh et al., 2013). Under $\mathrm{Cd}$ stress, severe deleterious effects on various photosynthetic indices such as photosynthetic rate (Pn) and intracellular $\mathrm{CO}_{2}$ concentration $(\mathrm{Ci})$ have been reported in tomato seedlings (Dong et al., 2005). Maleva et al. (2012) have observed that $\mathrm{Mn}, \mathrm{Cu}, \mathrm{Cd}, \mathrm{Zn}$, and $\mathrm{Ni}$ caused a significant decline in the levels of chlorophyll contents, accompanied by a decrease in the photochemical efficiency of photosystem II (PS II) in Elodea densa. Similarly, Li et al. (2012) have also reported that $\mathrm{Cu}, \mathrm{Zn}, \mathrm{Pb}$, and $\mathrm{Cd}$ depressed chlorophyll and carotenoids levels and the quantum yield of PS II in Thalassia hemprichii, 
indicating that heavy metals have negative consequences on photosynthesis. Apart from affecting light reactions, heavy metals decrease $\mathrm{CO}_{2}$ assimilation by either diminishing RUBP carboxylase activity or by reacting with the thiol group of RUBISCO. For instance, $\mathrm{Zn}$ has been reported to inhibit RUBISCO activity in Phaseolus vulgaris by replacing $\mathrm{Zn}^{+2}$ for $\mathrm{Mg}^{+2}$, as both are bivalent cations (Monnet et al., 2001). In another study on Erythrina variegate by Muthuchelian et al. (2001), decreased RUBISCO activity was observed under Cd stress, and this decrease in RUBISCO activity might be due to the formation of mercaptide by $\mathrm{Cd}$ with thiol group of RUBISCO (Siborova, 1988). These researchers also reported decreased $\mathrm{CO}_{2}$ fixation, which is possibly due to a decrease in ATP and reductant pool (Husaini and Rai, 1991), as Cd ions decrease the proton source for reduction reactions (Ferretti et al., 1993). Similarly, Cu, a well-known inhibitor of carboxylase and oxygenase activities of RUBISCO (Lidon and Henriques, 1991), was found to decrease RUBISCO activity in Chenopodium rubrum (Schafer et al., 1992) by interacting with the essential cysteine residue of the enzyme (Siborova, 1988). Such reduction in pigments, photosynthetic rate, quantum yield of PS II, gas exchange, stomatal conductance, and $\mathrm{CO}_{2}$ assimilation might be linked to the ultrastructural changes (changes at cellular and tissue levels) induced by heavy metal stress. The effects arising due to changes in ultrastructures of membranes have been reported in several studies (Azzarello et al., 2012; Basile et al., 2012; Esposito et al., 2012; He et al., 2012; Sánchez-Pardo et al., 2012; Ali et al., 2013a,b). Moreover, heavy metals have been reported to affect another key physiological process, i.e., nitrogen metabolism, which is involved in plant function, from metabolism to allocation of resources, thereby regulating plant growth and development. Heavy metals have been found to enhance protease activity (Chaffei et al., 2003), and thus, reducing the activity of enzymes involved in nitrate (Nitrate reductase; NR and Nitrite reductase; $\mathrm{NiR}$ ) and ammonia (Glutamine synthetase; GS, Glutamine oxoglutarate aminotransferase; GOGAT and Glutamate dehydrogenase; GDH) assimilation. The heavy metal $\mathrm{Cd}$ has been reported to affect nitrogen metabolism by inhibiting nitrate uptake and transportation, nitrate reductase, and GS activity (Hernández et al., 1997; Lea and Miflin, 2004), thereby affecting primary $\mathrm{N}$ assimilation processes.

Heavy metal-mediated alteration in hormonal balance correlates with their toxicities in plants (Petö et al., 2011; Wilkinson et al., 2012). For instance, in Brassica juncea, As causes toxicity by changing the levels of the auxins:indole3-acetic acid (IAA), indole-3- butyric acid (IBA), and naphthalene acetic acid (NAA) and altering the expression of about 69 microRNAs (Srivastava et al., 2013). However, exogenous supply of IAA improves the growth of $B$. juncea under As stress, suggesting an implication of the regulation of the hormone level in the management of As stress.

\section{Metallophytes under Heavy Metal Stress}

Metallophytes, also known as hyperaccumulators, have the ability to uptake large amounts of heavy metals from the soil, and this property makes them unique to be utilized in technologies such as biogeochemical and biogeobotanical prospection and phytoremediation. The absorbed heavy metals from the soil by these hyperaccumulators are not retained in the roots but are translocated to the shoots and accumulated in the aboveground organs at concentrations 100-1000-fold higher than the observed in non-hyperaccumulating species (Figures 2ia,b). However, this high concentration does not pose any toxic effect on plants (Rascio, 1997; Reeves, 2006; Prasad et al., 2010). With significant advances in our understanding of the mechanisms adopted by hyperaccumulators, there has been implication of three hallmarks that distinguish them from non-hyperaccumultors. These are (i) greater capability of heavy metal uptake, (ii) rootto-shoot translocation of heavy metal, and (iii) detoxification and sequestration of heavy metal (Figures 2iia-c). Studies on Thlaspi caerulescens and A. halleri, model plants for studying heavy metal tolerance strategies, have been done (Milner and Kochian, 2008; Singh et al., 2009; Frérot et al., 2010; Krämer, 2010). The studies have revealed that hyperaccumulation is not due to the presence of a novel gene, but it arises only from differential expression of genes that are common to hyperaccumulators and non-hyperaccumulators (Verbruggen et al., 2009). Hyperaccumulation of heavy metal includes three complex phenomena discussed below:

\section{Heavy Metal Uptake}

Hyperaccumulators have an extraordinary ability to absorb heavy metals from the soil under varying concentration of heavy metals (Ma et al., 2001; Yang et al., 2002). Although heavy metals are taken up by hyperaccumulators, their uptake is affected by several factors such as $\mathrm{pH}$, water content, organic substances, etc. Moreover, heavy metal uptake requires a suitable transporting system to enter the plant (Figure 2i). Several researchers have reported that $\mathrm{pH}$ affects (i) proton secretion by roots that further acidify rhizosphere, thus enhancing metal dissolution, and (ii) the growth of metal-accumulating plant species (Bernal et al., 1994; Peng et al., 2005; Kuriakose and Prasad, 2008). Apart from $\mathrm{pH}$, organic substances released from the roots affect growth in hyperaccumulating plants. Krishnamurti et al. (1997) have reported that organic acids released influence Cd solubility by forming $\mathrm{Cd}$ complexes. Therefore, $\mathrm{pH}$ and organic substances released from the rhizosphere of a hyperaccumulator mobilize heavy metal and enhance absorption (Krishnamurti et al., 1997; Peng et al., 2005). High uptake of heavy metal has also been associated with enhanced root proliferation (Whiting et al., 2000). Furthermore, constitutive overexpression of genes also attributes to enhanced heavy metal uptake. To pinpoint the genes involved in overexpression, several comparative studies have been performed in hyperaccumulating Arabidopsis halleri and Thlapsi caerulescens with that of congener non-hyperaccumulating species. Studies on $T$. caerulescens and $A$. halleri have revealed that increased $\mathrm{Zn}$ uptake is due to overexpression of genes belonging to the ZIP (Zincregulated transporter Iron-regulated transporter proteins) family encoding plasma membrane located transporters (Assunção et al., 2001): ZTN1 and ZTN2 in T. caerulescens and ZIP6 and ZIP9 in A. halleri. The decreased uptake of $\mathrm{Cd}$ under increasing $\mathrm{Zn}$ concentration was noticed in both genera, 
(i)
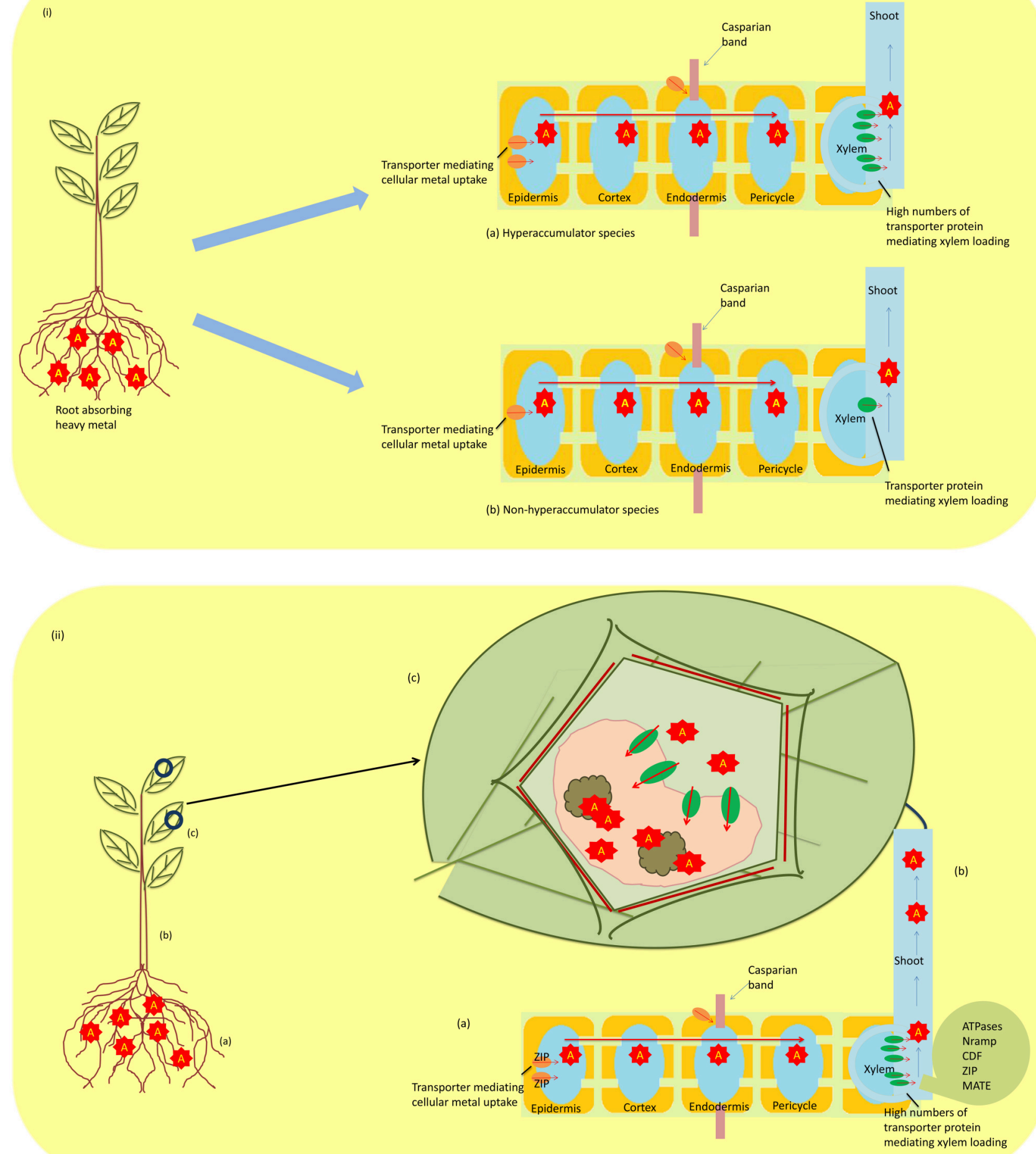

FIGURE 2 | (i) A schematic diagram showing differential expression of constitutive gene in regulating transporters in hyperaccumulating (a) and non-hyperaccumulating (b) species (A; heavy metal). (ii) Mechanism of metal tolerance in hyperaccumulators (a) metal uptake by roots; ZIP (zinc-regulated transporter iron-regulated transporter proteins) (b) translocation of metal from root to shoot; ATPases (or CPx-type, P1B-type), Nramp (natural resistance-associated macrophage protein), CDF (cation diffusion facilitator family proteins), zinc-iron permease (ZIP) family proteins, MATE (Multidrug and Toxin Efflux) family, and (c) sequestration of metal in vacuole. A, metal; B, organic acid. 
and it clearly demonstrated that expression of ZIP genes is $\mathrm{Zn}$ regulated (Assunção et al., 2010) and Cd influx is mainly due to $\mathrm{Zn}$ transporters having strong preference for $\mathrm{Zn}$ over Cd (Weber et al., 2006). Evidence exists that As being a chemical analog of phosphate enters the plant cell via phosphate transporters (Meharg and Hartley-Whitaker, 2002; Kanoun-Boulé et al., 2009). Similarly, a study on the As hyperaccumulator Pteris vittata and non-hyperaccumulator Pteris tremula has shown that plasma membranes of root cells of $P$. vittata had high density of phosphate/arsenate transporters than $P$. tremula (Caille et al., 2005), possibly due to constitutive gene overexpression. In addition, a study on the Se hyperaccumulators Astragalus bisulcatus (Fabaceae) and Stanleya pinnata (Brassicaceae) revealed that there was a higher $\mathrm{Se} / \mathrm{S}$ ratio in the shoots of these species in comparison to the non-hyperaccumulator sister species, and this observation also supported the fact that an enhanced Se uptake was through sulfate transporters (Galeas et al., 2007).

\section{Root-to-Shoot Translocation of Heavy Metals}

Unlike non-hyperaccumulator plants, hyperaccumulators do not retain the heavy metal absorbed from roots but translocate them into shoots via xylem and several classes of proteins are involved in this translocation. The proteins involved are heavy metal-transporting ATPases (or CPx-type, P1B-type), natural resistance-associated macrophage proteins (Nramp), cation diffusion facilitator (CDF) family proteins, zinc-iron permease (ZIP) family proteins, and MATE (Multidrug And Toxin Efflux) protein family. The CPx-type ATPases are involved in transporting toxic metals like $\mathrm{Cu}, \mathrm{Zn}, \mathrm{Cd}$, and $\mathrm{Pb}$ using ATP across cell membranes (Williams et al., 2000). The P1B-type ATPases also have the similar role of transporting heavy metal, but they also regulate metal homeostasis as well as tolerance (Axelsen and Palmgren, 1998). These heavy metal ATPases (HMAs) overexpressed in roots and shoots of hyperaccumulators suggest their upregulation in hyperaccumulators in comparison to non-hyperaccumulators (Papoyan and Kochian, 2004). Nramp is another class of protein family that has been found to be involved in transporting heavy metal ions, and genes coding for these proteins are termed as Nramp genes. Studies on rice revealed three homologs of this protein, namely OsNramp1, OsNramp2, and OsNramp3, and these proteins expressed in different tissues of rice transport distinct but related ions (Belouchi et al., 1997). Another class of proteins (CDF) have been found to be involved in transporting $\mathrm{Zn}, \mathrm{Co}$, and $\mathrm{Cd}$, and regulate effluxing of cation out of the cytoplasmic compartment, and therefore, they are termed as "cation efflux transporters" (Mäser et al., 2001). A related Zn transporter (ZNT1) from $T$. caerulescens was reported by Pence et al. (2000), which belongs to a superfamily known as ZIP gene family, and was found to be expressed at high levels in roots and shoots. Another $\mathrm{Zn}$ transporter ZAT1 was also reported in Arabidopsis that was highly expressed in root tissues (van der Zaal et al., 1999). The transporter protein MATE is also involved in heavy metal translocation; FDR3, a protein of this family, was found to be expressed in roots of T. caerulescens and A. halleri, and the gene encoding this protein FDR3 plays a role in translocation of heavy metal (Talke et al., 2006; van de Mortel et al., 2006; Krämer et al., 2007). Therefore, the abovementioned studies provide strong evidence that multiple transporter proteins are involved in the translocation of heavy metal.

\section{Detoxification/Sequestration of Heavy Metal}

After translocating, hyperaccumulators sequestrate and then detoxify the heavy metal, a process that allows them to survive under metal-contaminated areas without suffering from any toxic effect (Figure 2ii). The process of detoxification/sequestration occurs in the vacuole of plants (Vögeli-Lange and Wagner, 1990; Kanoun-Boulé et al., 2009; Singh et al., 2011a) and several transporter families are involved in this process, namelyABC, CDF, HMA, and NRAMP transporters. The ABC transporters are involved in transporting heavy metal into the vacuole and mainly two subfamilies (MRP and PDR) are active. The HMT1, first vacuolar $\mathrm{ABC}$ transporter reported in Schizosaccharomyces pombe, localized in the tonoplast aids in transporting PC$\mathrm{Cd}$ (phytochelatins-cadmium) complexes formed in the cytosol (Ortiz et al., 1992, 1995; Kuriakose and Prasad, 2008). Later on, a functional homolog of HMT1 has been reported in Caenorhabditis elegans and Drosophila (Vatamaniuk et al., 2005; Sooksa-Nguan et al., 2009); however, no such homolog was studied in plants. Studies in A. thaliana have revealed two transporters AtMRP1 and AtMRP2 in transporting PC-Cd complexes into the vacuole ( $\mathrm{Lu}$ et al., 1997, 1998), and these transporters confer the metal tolerance. The CDF transporter family, also named "metal tolerance protein (MTP)," is also involved in transporting metal cations such as $\mathrm{Zn}^{2+}, \mathrm{Cd}^{2+}$, $\mathrm{Co}^{2+}, \mathrm{Ni}^{2+}$, or $\mathrm{Mn}^{2+}$ from the cytosol to the vacuole (Krämer et al., 2007; Montanini et al., 2007). They have been categorized into two of four distinct groups of which groups I and III are the most important (Blaudez et al., 2003). Comparative studies in A. halleri and T. caerulescens with those of nonhyperaccumulators have shown higher expression of MTP1 (group III), MTP8 (group I), and MTP11 (group I) (Becher et al., 2004; Talke et al., 2006; van de Mortel et al., 2006). Similarly, AhMTP1 protein also showed a constitutive higher expression in leaves of A. halleri under exogenous supply of $\mathrm{Zn}$ (Dräger et al., 2004). The MTP11 and MTP8 were found to be close homologs of ShMTP8 (formerly ShMTP1) and confirmed Mn tolerance in A. thaliana (Delhaize et al., 2003), thus suggesting a role of these proteins in metal tolerance. Likewise, other transporter proteins such as HMA and NRAMP are also involved in transporting the metal from the cytosol to the vacuole. However, HMAs are thought to be involved in detoxification mechanisms due to their overexpression, as reported in A. thaliana (Morel et al., 2009).

Apart from the role of transporter proteins, organic acids are also involved in detoxification mechanisms, as they help in entrapping the metal ion and chelating them. For instance, citrate binds with $\mathrm{Ni}$ in leaves of Thlaspi goesingense, enabling formation of metal-organic acid complex for chelation (Krämer et al., 2000). Similarly, malate binds with $\mathrm{Zn}$ in A. halleri and Cd in T. caerulescens (Salt et al., 1999; Sarret et al., 2002). The role of amino acids in hyperaccumulator has been found to be important due to the formation of stable complexes with bivalent cations (Callahan et al., 2006), thus helping largely in sequestrating 
metal cations. For example, histidine (His) is involved in $\mathrm{Ni}$ hyperaccumulation, and a high concentration of His has been reported in the roots of $\mathrm{Ni}$ hyperaccumulators (Assuncão et al., 2003). The mechanism of heavy metal detoxification in hyperaccumulators also relies on the overexpression of genes related with antioxidant activity such as reduced glutathione (GSH), cysteine and $O$-acetylserine (Anjum et al., 2014). Studies have revealed that upstream signaling of salicylic acid results in increased serine acetyltransferase (SAT) activity and higher GSH level (Freeman et al., 2005a). Similarly, overexpression of NgSAT in Noccaea goesingense resulted in enhanced levels of GSH that resulted in $\mathrm{Ni}, \mathrm{Co}, \mathrm{Zn}$, and to a small extent Cd tolerance (Freeman et al., 2004; Freeman and Salt, 2007).

\section{HEAVY METAL AND REACTIVE OXYGEN SPECIES (ROS) PRODUCTION}

Another negative consequence of heavy metal accumulation is the generation of ROS. In plants, ROS accumulation depends upon the balance between ROS production and ROS scavenging (Mittler et al., 2004), which in turn also depends on growth conditions such as temperature, light intensity, presence of heavy metal, etc. For instance, the presence of excess heavy metals results into a limitation of $\mathrm{CO}_{2}$ fixation in the chloroplasts, which coupled with an over reduction of the photosynthetic electron transport chain serves as a major site of ROS production (Mittler et al., 2004). Over reduction of the electron transport chains in the mitochondria is also a major site of ROS generation (Davidson and Schiestl, 2001; Keunen et al., 2011). Møller et al. (2007) reported that $1-5 \%$ of $\mathrm{O}_{2}$ consumed by the isolated mitochondria converts into ROS. ROS hydrogen peroxide $\left(\mathrm{H}_{2} \mathrm{O}_{2}\right)$ is produced in the peroxisomes after glycolate is oxidized to glyoxylic acid during photorespiration (Mittler et al., 2004). Therefore, ROS such as singlet oxygen $\left({ }^{1} \mathrm{O}_{2}\right)$, superoxide anion $\left(\mathrm{O}_{2}^{\bullet-}\right), \mathrm{H}_{2} \mathrm{O}_{2}$, and hydroxyl radicals $\left({ }^{\bullet} \mathrm{OH}\right)$ are produced in these organelles because of spin inversion and one-two and three-electron transfer reactions to $\mathrm{O}_{2}$, respectively, during functioning of the electron transport chains (Sharma and Dietz, 2009). The redox active heavy metals such as $\mathrm{Cu}, \mathrm{Cd} \mathrm{Fe}$, and $\mathrm{Zn}$ can induce ROS formation directly by participating in Haber-Weiss and Fenton reactions or indirectly by inhibiting the functioning of enzymes in the cellular antioxidant defense network (Schützendübel and Polle, 2002; Halliwell, 2006; Keunen et al., 2011).

ROS are unstable, highly reactive, and thus, promptly react with other macromolecules to generate more free radicals because unpaired electrons tend to pair and give rise to two stable electron bonds (Foyer and Halliwell, 1976). Being extremely reactive in nature, ROS can interact with macromolecules such as DNA, pigments, proteins, lipids, and other essential cellular molecules depending on the properties like chemical reactivity, redox potential, half-life, and mobility within the cellular system, ultimately leading to a series of destructive processes collectively termed as "oxidative stress" (Mittler, 2002; Sharma and Dietz, 2009; Hossain et al., 2012a,b). Among ROS, $\bullet \mathrm{OH}$ is the most reactive, highly damaging, and short-lived
(1 ns), and can oxidize macromolecules within a diffusion distance. Therefore, ROS might induce reversible as well as irreversible modifications in lipids, proteins, and nucleic acids; however, most of these ROS effects are damaging and irreversible.

Conversely, ROS also act as signaling molecules involved in the regulation of many key physiological processes such as root hair growth, stomatal movement, cell growth, and cell differentiation when finely tuned and regulated by an antioxidative defense system (Foreman et al., 2003; Kwak et al., 2006; Tsukagoshi et al., 2010). It has been shown in several studies that ROS generated by NADPH oxidases during stress are channeled by the plant to serve as a stress signal to activate acclimation and defense mechanisms, which in turn counteract oxidative stress (Mittler et al., 2004; Davletova et al., 2005; Miller et al., 2008, 2010). Therefore, the fate of ROS (i.e., whether it will act as signaling molecule or damaging one) in the cellular system depends upon the output of many complex processes that involve in antioxidative system, signaling cascades, redox alterations, etc. When the generation of ROS exceeds that of the scavenging potential of antioxidants, oxidative stress occurs (Figure 3).

Plants possess a specific mechanism to keep the routinely formed ROS at physiological limit, preventing them from exceeding toxic threshold levels, thereby playing an important role in the acclimation process against an imposed stress (Mittler et al., 2004). This mechanism is known as the plant antioxidant defense system that regulates ROS levels in the cellular system at a particular time (Figure 3). An antioxidant system comprises two types of components: enzymatic and non-enzymatic. The enzymatic antioxidants include superoxide dismutase (SOD; EC 1.15.1.1), catalase (CAT; EC 1.11.1.6), ascorbate peroxidase (APX; EC 1.11.1.11), glutathione reductase (GR; EC 1.6.4.2), monodehydroascorbate reductase (MDHAR; EC 1.6.5.4), dehydroascorbate reductase (DHAR; EC 1.8.5.1), glutathione peroxidase (GPX; EC 1.11.1.9), and glutathione-S-transferase (GST; EC 2.5.1.18), whereas nonenzymatic antioxidants include water-soluble compounds such as ascorbate, glutathione, proline, and $\alpha$-tocopherol (Apel and Hirt, 2004; Sharma and Dietz, 2009; Hossain et al., 2011, 2012a,b). Although ascorbate and glutathione both function as cofactors of enzymatic antioxidants, both can also directly quench ROS and regulate the gene expression associated with biotic and abiotic stress responses (Hossain et al., 2012a,b). The importance of antioxidants is based on the facts that their increased and/or decreased levels are generally related to an enhanced or declined stress tolerance of stressed plants. Since the evolution of $\mathrm{O}_{2}$, antioxidants play an important role in sustaining ROS concentration at an appropriate level that can promote plant development and reinforce resistance to stressors by modulating the expression of a set of genes and redox signaling pathways (Neill et al., 2002). Keeping into consideration the importance of antioxidants in managing ROS levels and oxidative stress, the responses of transgenic plants and/or organisms overexpressing antioxidant and/or its biosynthetic pathway gene(s) against heavy metal stress are listed in Table 1. 


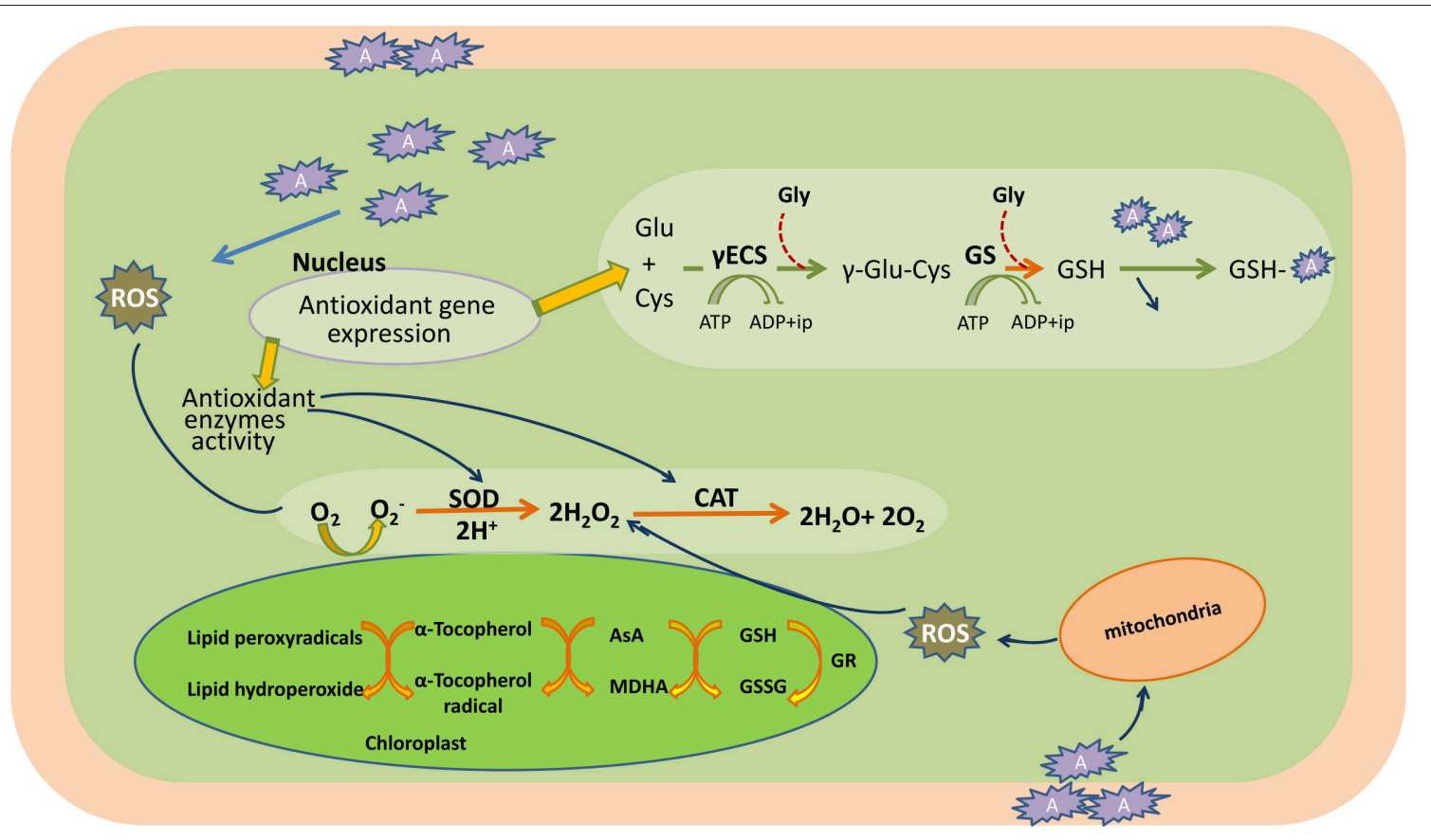

FIGURE 3 | Heavy metal induced-oxidative stress, tolerance, and detoxification mechanisms in the plant cell. AsA, ascorbic acid; CAT, catalase; Cys, cysteine; c-ECS, c-glutamylcysteinesynthetase; Glu, glutamine; Gly, glycine; GR, glutathione reductase; GS, glutathione synthetase; GSH, glutathione (reduced); GSSG, oxidized glutathione; $\mathrm{H}_{2} \mathrm{O}_{2}$, hydrogen peroxide; MDHA, monodehydroascorbate; $\mathrm{O}_{2}$, oxygen molecule; $\mathrm{O}_{2}^{-}$, superoxide radicals; ROS, reactive oxygen species; SOD, superoxide dismutase; A, heavy metal.

\section{Plant Antioxidant Defense System}

The term "antioxidant" refers to a class of compounds that protect cells from damage caused by exposure to certain highly reactive species like ROS. The network and coordination of antioxidants are solely responsible for removing, neutralizing, and scavenging ROS. SOD is an enzyme involved in dismutating superoxide radicals generated by oxidation of molecular oxygen into $\mathrm{H}_{2} \mathrm{O}_{2}$ and $\mathrm{O}_{2}$ in all the cellular compartments (Fridovich, 1989).

$\mathrm{H}_{2} \mathrm{O}_{2}$ produced by the action of SOD is quite dangerous as it can diffuse through the membrane very easily and damage other cellular components, and thus, metabolites (ascorbate and glutathione) and enzymes (monodehydroascorbate reductase; MDHAR, dehydroascorbate reductase; DHAR and glutathione reductase; GR) are implicated in scavenging of $\mathrm{H}_{2} \mathrm{O}_{2}$ (Foyer et al., 1997). Three types of SODs have been reported in plants on the basis of the metal containing (1) the chloroplastic or cytosolic $\mathrm{Cu}-\mathrm{Zn} \mathrm{SOD}$; the cytosolic $\mathrm{Cu}-\mathrm{Zn}$ SOD is referred to as $\mathrm{Cu}-\mathrm{Zn}$ SOD I, whereas the chloroplastic one is referred to as $\mathrm{Cu}-\mathrm{Zn}$ SOD II; (2) Mitochondrial Mn SOD, and (3) the chloroplastic Fe SOD. APX is regarded as a housekeeping protein in the cytosol and chloroplast, and is involved in scavenging of $\mathrm{H}_{2} \mathrm{O}_{2}$. The substrate for this enzyme is ascorbate and the product, which is a radical, is reduced to dehydroascorbate by an enzyme MDHAR in the presence of an electron donor NADPH (Asada, 1992, 1996). CAT is an important oxidoreductase enzyme that catalyzes decomposition of $\mathrm{H}_{2} \mathrm{O}_{2}$ into $\mathrm{H}_{2} \mathrm{O}$ and $\mathrm{O}_{2}$, and it is found in most plants and is localized in the peroxisome. CAT is a key enzyme involved in detoxifying peroxides generated during photorespiration (Morita et al., 1994; Lin and Kao, 2000). Although APX and CAT serves the same function of detoxifying, different affinities (on the basis of Km values) of APX and CAT depict the role of APX in modulating $\mathrm{H}_{2} \mathrm{O}_{2}$ for signaling and CAT in detoxifying excess $\mathrm{H}_{2} \mathrm{O}_{2}$ during stress (Mittler, 2002).

The above mentioned enzymatic components play a relevant role in mitigating heavy metal stress. Several studies have revealed that treatment of heavy metal enhances ROS formation, and thus, substantial increase in the activities of SOD, CAT, and APX was observed (Bharwana et al., 2013; Bashri and Prasad, 2015). A study by Wang et al. (2004) revealed a considerable increase in the activities of POD, APX, and SOD under Cu stress in B. juncea seedlings. Similarly, Bharwana et al. (2013) showed that under $\mathrm{Pb}$ treatment, there was an appreciable rise in SOD, guaiacol peroxidase, APX and CAT activities, and their activities were further enhanced with the rising concentration of $\mathrm{Pb}$ from 50 to $100 \mu$ M. Similar to this, Singh et al. (2013) reported increased activity of SOD and CAT under As exposure (5 and $50 \mu \mathrm{M})$. These results suggest that cooperative action of antioxidants is required for a detoxification mechanism under heavy metal stress.

\section{“OMICS" TOOLS}

\section{Metabolomics}

Metabolomics refers to the identification and quantification of all low-molecular weight metabolites required by the organisms 
TABLE 1 | Summary of transgenic plants over-expressing gene(s) of enzymatic and non-enzymatic antioxidants and their performance against heavy metal stress.

\begin{tabular}{|c|c|c|c|c|}
\hline $\begin{array}{l}\text { Antioxidant and/or its } \\
\text { biosynthetic pathway } \\
\text { gene(s) }\end{array}$ & Source & Target transgenic & Response of transgenic plants and/or organisms & References \\
\hline CAT3 & Brassica juncea & Nicotiana tabacum & $\begin{array}{l}\text { Cd stress tolerance, better seedling growth, and longer } \\
\text { roots }\end{array}$ & Gichner et al., 2004 \\
\hline CAT & Brassica juncea & Nicotiana tabacum & $\begin{array}{l}\mathrm{Zn} \text { and } \mathrm{Cd} \text { stress tolerance, 2.0-fold higher CAT activity } \\
\text { than wild type, lower } \mathrm{H}_{2} \mathrm{O}_{2} \text { level, and cell death }\end{array}$ & Guan et al., 2009 \\
\hline CAT1 and CAT2 & Brassica oleracea & Arabidopsis & Low level of $\mathrm{H}_{2} \mathrm{O}_{2}$ and enhanced stress tolerance & Chiang et al., 2013 \\
\hline Cu/ZnSOD and/or CAT & Zea mays & Brassica campestris & $\begin{array}{l}\text { Less reduction in photosynthetic activity than wild type } \\
\text { under } \mathrm{SO}_{2} \text { stress }\end{array}$ & Tseng et al., 2007 \\
\hline MnSOD & Triticum aestivum & Brassica napus & $\begin{array}{l}\text { SOD activity was } 1.5-2.5 \text {-fold greater than wild type and } \\
\text { enhanced Al tolerance }\end{array}$ & Basu et al., 2001 \\
\hline$C u / Z n S O D$ and $A P X$ & - & Festuca arundinacea & $\begin{array}{l}\text { Increased tolerance against } \mathrm{Cu}, \mathrm{Cd} \text {, and As due to } \\
\text { depressed oxidative stress }\end{array}$ & Lee et al., 2007 \\
\hline cytGR/cpGR & Bacterial & Brassica juncea & $\begin{array}{l}\text { cpGR transgenic showed lower Cd accumulation and } 50 \\
\text { times higher GR activity than wild type plants }\end{array}$ & Pilon-Smits et al., 2000 \\
\hline$G R$ & Brassica rapa & Escherichia coli & $\begin{array}{l}\text { Increased tolerance against } \mathrm{H}_{2} \mathrm{O}_{2} \text { induced by } \mathrm{Cd}, \mathrm{Zn} \text {, } \\
\text { and } \mathrm{Al} \text { due to an enhanced } \mathrm{GR} \text { activity }\end{array}$ & Kim et al., 2009 \\
\hline$D H A R / G R / G S T$ & Escherichia coli & Nicotiana tabacum & $\begin{array}{l}\text { Overexpression enhanced metal tolerance due to } \\
\text { maintained redox couples such as ascorbate and } \\
\text { glutathione }\end{array}$ & Le Martret et al., 2011 \\
\hline$D H A R$ & Oryza sativa & Escherichia coli & $\begin{array}{l}\text { DHAR-overexpressing E. coli strain was more tolerant to } \\
\text { oxidant and metal-mediated stress conditions than the } \\
\text { control E. coli strain }\end{array}$ & Shin et al., 2008 \\
\hline$M D H A R / D H A R$ & Arabidopsis & Nicotiana tabacum & $\begin{array}{l}\text { DHAR but not MDHAR enhanced Al tolerance by } \\
\text { maintaining ascorbate level }\end{array}$ & Yin et al., 2010 \\
\hline GST & Trichoderma virens & Nicotiana tabacum & $\begin{array}{l}\text { Enhanced Cd tolerance simultaneously no Cd } \\
\text { accumulation, increased activity of SOD, CAT, GST, APX, } \\
\text { and GPX than wild type }\end{array}$ & Dixit et al., 2011 \\
\hline Sulfite oxidase (SO) & Zea mays & Nicotiana tabacum & $\begin{array}{l}\text { Increased tolerance against } \mathrm{S} \text { due to enhanced } \\
\text { CAT-mediated } \mathrm{H}_{2} \mathrm{O}_{2} \text { scavenging }\end{array}$ & Xia et al., 2012 \\
\hline TCPCS1 & Thlaspi caerulescens & $\begin{array}{l}\text { Saccharomyces cerevisiae } \\
\text { and Nicotiana tabacum }\end{array}$ & $\begin{array}{l}\text { Increased tolerance to } \mathrm{Cd} \text { due to the decreased lipid } \\
\text { peroxidation and enhanced activities of SOD, POD, and } \\
\text { CAT }\end{array}$ & Liu et al., 2011 \\
\hline Serine acetyltransferase & Thlaspi goesingense & Escherichia coli & $\begin{array}{l}\text { Imparts } \mathrm{Ni} \text { and Co tolerance due to involvement of } \\
\text { glutathione }\end{array}$ & Freeman et al., 2005a \\
\hline gshll & Escherichia coli & Brassica juncea & $\begin{array}{l}\text { Transgenic plants had higher level of glutathione, } \\
\text { phytochelatin, and thiols and thus showed enhanced Cd } \\
\text { tolerance }\end{array}$ & Liang Zhu et al., 1999 \\
\hline AsPCS1/GSH1 & $\begin{array}{l}\text { Allium } \\
\text { sativum/Saccharomyces } \\
\text { cerevisiae }\end{array}$ & Arabidopsis & $\begin{array}{l}\text { Elevated production of phytochelatin and glutathione } \\
\text { that imparts Cd and As tolerance }\end{array}$ & Guo et al., 2008a \\
\hline APS1 & Arabidopsis & Brassica juncea & Increased Se tolerance due to its rapid reduction & Pilon-Smits et al., 1999 \\
\hline MTH1745 & $\begin{array}{l}\text { Methanothermobacter } \\
\text { thermoautotrophicum }\end{array}$ & Oryza sativa & $\begin{array}{l}\text { Increased } \mathrm{Hg} \text { tolerance, higher photosynthesis, } \mathrm{SOD} \text { and } \\
\mathrm{POD} \text { activity, and lower superoxide radicals, } \mathrm{H}_{2} \mathrm{O}_{2} \text {, and } \\
\text { lipid peroxidation than wild type }\end{array}$ & Chen et al., 2012b \\
\hline PCs & Arabidopsis & Nicotiana tabacum & $\begin{array}{l}\text { Enhanced Cd tolerance and hampers root-to-shoot Cd } \\
\text { transport }\end{array}$ & Pomponi et al., 2006 \\
\hline PCS1 & Arabidopsis & Arabidopsis & Enhanced As tolerance but increased Cd hypersensitivity & Li et al., 2004 \\
\hline PCS & Anabaena sp. PCC 7120 & Escherichia coli & $\begin{array}{l}\text { Enhanced tolerance against multiple stresses such as } \\
\mathrm{Cd} \text { and } \mathrm{Cu} \text { by increasing phytochelatin production }\end{array}$ & Chaurasia et al., 2008 \\
\hline MT1 & Mus musculus & Nicotiana tabacum & Enhanced $\mathrm{Hg}$ accumulation and tolerance & Ruiz et al., 2011 \\
\hline MT1 & Paxillus involutus & Hebeloma cylindrosporum & Increased $\mathrm{Cu}$ and $\mathrm{Cd}$ tolerance & Bellion et al., 2007 \\
\hline $\begin{array}{l}\Delta 1 \text {-pyrroline-5- } \\
\text { carboxylate } \\
\text { synthetase }\end{array}$ & Vigna aconitifolia & Chlamydomonas reinhardtii & $\begin{array}{l}\text { Transgenic grows rapidly in toxic Cd concentration } \\
(100 \mu \mathrm{M}), \text { and bind four-fold more Cd than wild-type } \\
\text { cells. Proline likely acts as an antioxidant in Cd-stressed } \\
\text { cells and thus increases Cd tolerance }\end{array}$ & $\begin{array}{l}\text { Siripornadulsil et al., } \\
2002\end{array}$ \\
\hline $\begin{array}{l}\text { Alkyl hydroperoxide } \\
\text { reductase }\end{array}$ & Anabaena sp. PCC 7120 & Escherichia coli & $\begin{array}{l}\text { Enhanced tolerance against } \mathrm{Cu} \text { and } \mathrm{Cd} \text { by enhancing } \\
\text { scavenging of } \mathrm{H}_{2} \mathrm{O}_{2} \text { and reactive sulfur species }\end{array}$ & Mishra et al., 2009b \\
\hline
\end{tabular}


during developmental stages (Arbona et al., 2013), and some metabolites have been reported to be involved under heavy metal stress tolerance strategies. In the following section, we discuss the role of metabolomics under heavy metal stress.

\section{Amino Acids and Amines}

Amino acids and their derivatives have been reported to chelate metal ions, thus conferring metal tolerance to plants. Amino acids, particularly proline and histidine, have been found to chelate metal ions in cells as well as in the xylem sap (Rai, 2002; Sharma and Dietz, 2006). Proline has been reported to accumulate under heavy metal stress (Talanova et al., 2000; Yusuf et al., 2012a). A study on microalgae has demonstrated an increased level of proline under Cd stress (Siripornadulsil et al., 2002). The mechanism of action of increased levels of proline is not sequestration, but it reduces the formation of free radicals and also maintains reducing environment by enhancing the level of GSH (Siripornadulsil et al., 2002). Histidine, another important amino acid, has been found to play an important role under heavy metal stress. Krämer et al. (1996) reported increased histidine levels in the xylem sap of Alyssum lesbiacum (Ni hyperaccumulator) under Ni stress. Similarly, Kerkeb and Krämer (2003) reported simultaneous uptake of $\mathrm{Ni}$ and Histidine in B. juncea. Changes in the histidine content have functional significance in metal stress tolerance (Sharma and Dietz, 2006). NA (aminocarboxylate), an amino acid derivative synthesized by condensation process of three S-adenosyl-L-methionine, has been also reported to chelate metal ions. They have been found to be involved in the movement of mineral nutrients (Stephan and Scholz, 1993). The physiological role of NA has been confirmed by studying the tomato mutant lacking NA synthase, an enzyme involved in catalyzing formation of NA, which showed accumulation of $\mathrm{Fe}$ and $\mathrm{Cu}$ (Scholz et al., 1985; Herbik et al., 1996). Apart from its chelating action, NA has been reported to be precursor of phytosiderophore mugineic acid involved in binding metals such as $\mathrm{Zn}, \mathrm{Cu}$, and Fe (Treeby et al., 1989).

\section{Organic Acids}

Organic acids such as malate, citrate, and oxalate have been reported to transport metals through xylem and are involved in sequestrating ions in vacuole (Rauser, 1999). Citrate, synthesized from citrate synthase, has been shown to have high affinity for $\mathrm{Fe}, \mathrm{Ni}$, and $\mathrm{Cd}$, but it is majorly involved in chelating $\mathrm{Fe}$ (Cataldo et al., 1988). Malate has been reported to chelate $\mathrm{Zn}$ and is mainly involved in chelating cytosolic ions (Mathys, 1977).

\section{Glutathione and $\alpha$-Tocopherol}

Glutathione (GSH) is a water-soluble tripeptide thiol having low molecular weight (c-Glu-Cys-Gly) and plays a role in the cellular defense against the toxic actions of heavy metals (Meister and Anderson, 1983). Glutathione reductase (GR) readily converts an oxidized glutathione (GSSG) form to reduced form of GSH. GR contains a conserved disulfide bridge that breaks off under metal stress (Creissen et al., 1992; Lee et al., 1998) and plays an important role in defense by reducing GSSG, thus allowing a high GSH/GSSG ratio to be maintained. Studies on Luffa seedlings showed an increasing trend in GR activity with an increasing concentration of As (Singh et al., 2015). GR-catalyzed reduction of glutathione disulfide (GSSG) to glutathione (GSH) is NADPH dependent, and to maintain the proper ratio of GSH/GSSG, GSH biosynthesis must be initiated with rapid reduction in GSSG by GR (Kumar et al., 2012).

Alpha-tocopherol is the most active form of vitamin $\mathrm{E}$ and is synthesized in the plastids of higher plants. It is found to be involved in scavenging ROS and lipid peroxides (Munne-Bosch, 2005) by quenching ${ }^{1} \mathrm{O}_{2}$ in the chloroplast and thus, prevents cell membrane from damage under stress. Several studies have reported changes in the levels of $\alpha$-tocopherol under heavy metal stress (Collin et al., 2008; Yusuf et al., 2010; Kumar et al., 2012; Lushchak and Semchuk, 2012). A study by Collin et al. (2008) reported an increased concentration of $\alpha$-tocopherol in Arabidopsis under $\mathrm{Cd}$ treatment, and the authors suggested that there is an upregulation of genes related to its biosynthesis (Figure 3).

\section{Phenols}

Synthesis of phenolic compounds under heavy metal stress is due to their high tendency to chelate metals, which is due to the presence of hydroxyl and carboxyl groups that bind to metal ions particularly iron and copper (Jun et al., 2003). Winkel-Shirley (2002) reported induction of phenolic compounds in maize under aluminum exposure. Similarly, Diáz et al. (2001) reported accumulation of phenols in leaves of $P$. vulgaris when exposed to $\mathrm{Cu}$ stress. This increase in phenolics is correlated with increased activity of enzymes involved in biosynthesis of phenols under heavy metal stress. Phenols have been reported to be directly involved in chelating Fe ions and thus, suppressing Fenton's reaction, which is the important source of ROS production. Stimulation of CHS (Chalcone synthase) and PAL (phenylalanine ammonia-lyase) activities has been reported in several plants exposed to $\mathrm{Cu}, \mathrm{Cd}, \mathrm{Al}, \mathrm{Pb}$, and $\mathrm{Ni}$ (Babu et al., 2003; Sobkowiak and Deckert, 2006; Kováčik and Klejdus, 2008; Kováčik et al., 2009; Pawlak-Sprada et al., 2011). Lavid et al. (2001) reported that tea plants rich in tannin are tolerant to $\mathrm{Mn}$ and prevent from $\mathrm{Mn}$ toxicity by directly chelating the $\mathrm{Mn}$.

\section{Ionome and Ionomics}

Ionome includes the role of mineral nutrients, namely nitrogen $(\mathrm{N})$, phosphorus $(\mathrm{P})$, potassium $(\mathrm{K})$, calcium $(\mathrm{Ca})$, sulfur $(\mathrm{S})$ and magnesium $(\mathrm{Mg})$ and trace metals namely iron $(\mathrm{Fe})$, copper $(\mathrm{Cu})$, manganese $(\mathrm{Mn})$, molybdenum $(\mathrm{Mo})$, cobalt $(\mathrm{Co})$, and zinc (Zn) in alleviating heavy metal toxicity. Although all the mineral nutrients and trace elements are essential for growth and development processes of plants, concentration greater than the required level becomes toxic to the plants. Apart from posing toxicity at higher concentration, nutrients under safe limit play important role in alleviating toxicity induced by heavy metals.

Nitrogen is the most essential nutrient as it is the major constituent of proteins, nucleic acids, vitamins, and hormones. It has the potentiality of alleviating heavy metal toxicity, as it enhances the photosynthetic capacity by increasing chlorophyll synthesis, often synthesizes $\mathrm{N}$-containing metabolites like proline, GSH, etc. and by enhancing the activity of antioxidant enzymes (Sharma and Dietz, 2006; Lin et al., 2011). In a study 
by Pankovic et al. (2000), it has been shown that supplementing $7.5 \mathrm{mM}$ (optimal level) of $\mathrm{N}$ to sunflower reduced the inhibitory effect of Cd on photosynthesis by enhancing Rubisco activity and by increasing protein content. In another study by Zhu et al. (2011), it has been shown that supplementing $\mathrm{N}$ fertilizer in the form of $16 \mathrm{mM}\left(\mathrm{NH}_{4}\right)_{2} \mathrm{SO}_{4}$, alleviated Cd-induced toxicity in Sedum. The alleviating potential not only depends on the supplemented level of $\mathrm{N}$ but also on the source of $\mathrm{N}$. For instance, when $\mathrm{N}$ was applied in the form of $\mathrm{NH}_{4}^{+}-\mathrm{N}$, it reduced the $\mathrm{Cd}$ concentration in leaves of rice plants that was found to be below $100 \mathrm{mg} \mathrm{kg}^{-1}$ (Jalloh et al., 2009), but when supplemented as $\mathrm{NO}_{3}^{-} \mathrm{N}$, it increased the $\mathrm{Cd}$ concentration, which suggests antagonistic behavior of $\mathrm{NH}_{4}^{+}$- while synergistic of $\mathrm{NO}_{3}^{-}$toward $\mathrm{Cd}$. Another mineral nutrient, phosphorus $(\mathrm{P})$ is the major constituent of cell membrane and nucleic acid, and majorly required for phosphorylation reaction. It has also been reported in alleviating metal-induced toxicity either by diluting the metal or by decreasing the mobility of the metal by forming metalphosphate complex (Sarwar et al., 2010). In addition, P can also increase GSH content and prevent membrane damage, thereby conferring tolerance to plants (Wang et al., 2009).

Potassium $(\mathrm{K})$ ion is required by the plant to maintain anion-cation balance in cells and plays important regulatory role in protein synthesis and enzyme activation. By improving nutritional status of $\mathrm{K}$, condition of oxidative stress in plants can be minimized (Shen et al., 2000). Supplementation of $\mathrm{K}$ at $60 \mathrm{mg} \mathrm{kg}^{-1}$ alleviated the toxicity induced by $\mathrm{Cd}$ at $25 \mathrm{mg}$ $\mathrm{kg}^{-1}$ by increasing the content of AsA and GSH. Similar to nitrogen, $\mathrm{K}$ source may also play an important role in alleviating toxicity. A study by Zhao et al. (2004) clearly demonstrated that application of $\mathrm{KNO}_{3}, \mathrm{~K}_{2} \mathrm{SO}_{4}$, and $\mathrm{KCl}$ at the rate of 55,110 , and $166 \mathrm{mg} . \mathrm{K}^{\mathrm{kg}}{ }^{-1}$, respectively, to the soil has differential effect on $\mathrm{Cd}$ (concentration $15 \mathrm{mg} \mathrm{Kg}^{-1}$ ) accumulation. When $\mathrm{KCl}$ and $\mathrm{K}_{2} \mathrm{SO}_{4}$ were applied in increasing concentration from 0 to $55 \mathrm{mg}$ $\mathrm{kg}^{-1}$, there was $60-90 \%$ increase in Cd accumulation in shoots, whereas similar increasing concentrations of $\mathrm{KNO}_{3}$ increased the Cd content very marginally, suggesting its protective action against $\mathrm{Cd}$ stress.

Sulfur (S), another mineral nutrient, serves as an important constituent of several coenzymes, vitamins, and ferredoxin. Wangeline et al. (2004) reported that Cd toxicity could be alleviated by the upregulation of S-assimilation pathway, thus suggesting toward alleviating role of $S$ under heavy metal toxicity. Studies on Triticum aestivum (Khan et al., 2007), B. juncea (Wangeline et al., 2004), and Arabidopsis (Howarth et al., 2003) have shown increased ATP-sulfurylase (ATPS) and serine acetyl transferase (SAT) activities under Cd stress, and thereby conferring tolerance to these plants. As ATPS activity helps in maintaining GSH level required for regulating Ascorbate (AsA)GSH cycle (Khan et al., 2009), it has been reported that $S$ at $40 \mathrm{mg} . \mathrm{S}^{\mathrm{Kg}}{ }^{-1}$ enhanced the AsA-GSH cycle, thereby reducing Cd-induced toxicity in mustard (Anjum et al., 2008). Thus, indicating toward the possibility that $S$ supplementation to soil system might enhance the formation of S-containing defense compounds such as GSH and phytochelatins. Study by Astolfi et al. (2004) has shown that $\mathrm{Cd}(100 \mu \mathrm{M})$ exposure enhanced the ATPS, $\mathrm{O}$-acetyl serine (OAS) thiol lyase activity, which is related to the production of phytochelatins that play the most effective detoxifying mechanism in plants (Zhang et al., 2010). Apart from enhancing the formation of phytochelatins, $S$ also regulates ethylene signaling and thereby helping under heavy metal stress (Masood et al., 2012). Calcium (Ca) is majorly involved in activating the enzymes and also plays an important role in regulating metabolic activities. Due to chemical similarity as well as due to same channels and intracellular Ca-binding sites (Lauer Júnior et al., 2008) of $\mathrm{Ca}^{+2}$ and $\mathrm{Cd}^{+2}$, Cd present in external medium, replaces the $\mathrm{Ca}$, and thereby affects the growth of plant. However, $\mathrm{Ca}$ has been shown to decrease the heavy metal-induced toxicity (Suzuki, 2005; Farzadfar et al., 2013). It has been reported that $30 \mathrm{mM}$ Ca reduced the Cd content from 46.7 to $17.4 \mu \mathrm{g}$ in Arabidopsis seedlings (Suzuki, 2005). Similar to this, Zhenyan et al. (2005) reported enhanced Cd (concentration $0.5 \mathrm{mM}$ ) tolerance in Lactuca sativa when supplied with $4 \mathrm{mM}$ $\mathrm{CaCl}_{2}$, which was due to enhanced expression of phytochelatin synthase. Ca reduces heavy metal-induced toxicity by reducing their uptake, influencing physiological processes, or activating expressions of other defense compounds.

Magnesium (Mg), an important constituent for chlorophyll biosynthesis, plays an essential role under heavy metal toxicity. Abul Kashem and Kawai (2007) reported that Cd $(0.25 \mu \mathrm{M})$ induced toxicity in Japanese mustard spinach was alleviated by $\mathrm{Mg}$ at $10 \mathrm{mM}$, and $\mathrm{Cd}$ accumulation was reduced by $40 \%$. Mginduced alleviation is not due to inhibition in uptake but due to enhanced antioxidant enzymes (Chou et al., 2011). Moreover, Mg-induced alleviation has been also correlated with expression of some genes OsIRT1, OsZIP1, and OsZIP3 of rice.

Trace elements are required in lesser amount for the biological system, which include iron $(\mathrm{Fe})$, copper $(\mathrm{Cu})$, manganese $(\mathrm{Mn})$, molybdenum (Mo), cobalt $(\mathrm{Co})$, and zinc $(\mathrm{Zn})$, and their high levels could be toxic. The essentialities of these trace metals are due to their active participation in the redox reactions as well as because of their roles as enzyme cofactors (Sanita di Toppi and Gabbrielli, 1999). However, apart from their roles in biological system, they have been reported to play a crucial role in alleviating metal toxicity. Several trace elements have direct as well as indirect effects on heavy metal availability and toxicity (Sarwar et al., 2010). Direct effects include lowered solubility of heavy metals in the soil (Hart et al., 2005; Shi et al., 2005; Matusik et al., 2008), competition between heavy metals and trace elements for the same membrane transporters (Baszynski et al., 1980; Qiu et al., 2005), and heavy metal sequestration in the vacuoles (Salt and Rauser, 1995; Zaccheo et al., 2006). Indirect effects include dilution of heavy metal concentration by increasing plant biomass (dilution effect) and alleviation of heavy metal stress by increasing antioxidant defense system (Hassan et al., 2005; Suzuki, 2005; Jalloh et al., 2009). Zn, being an important group of metal transporter family, has been suggested to prevent damage caused by $\mathrm{Cd}$ toxicity. As reported in the case of Thalpsi violacea, plants supplied with $2 \mathrm{mgL}^{-1} \mathrm{Cd}$ showed $48.5 \mathrm{mg} \mathrm{Kg}^{-1} \mathrm{Zn}$ accumulation than that of control $\left(16.8 \mathrm{mgKg}^{-1}\right)$, whereas when the plant was supplemented with $5 \mathrm{mgL}^{-1} \mathrm{Cd}$, Zn accumulation decreased upto $12.8 \mathrm{mg} \mathrm{Kg}^{-1}$, suggesting $\mathrm{Cd} / \mathrm{Zn}$ antagonism (Street et al., 2010). Furthermore, $\mathrm{Zn}$ also enhances the activities of antioxidant enzymes and 
competes with $\mathrm{Cd}$ to bind with the membrane protein in order to protect plant (Wu and Zhang, 2002). Other trace metal Fe, under Cd stress, showed reduced Cd uptake and translocation, thus increasing plant growth. Study by Qureshi et al. (2010) revealed that exogenous application of $40 \mu \mathrm{M}$ Fe reduces the condition of oxidative stress by stabilizing the thylakoid complex under $\mathrm{Cd}$ stress. It was also reported that at $\mathrm{Fe}$ concentrations of $1.89 \mathrm{mg} \mathrm{L}^{-1}$ (moderate) and $16.8 \mathrm{mg} \mathrm{L}^{-1}$ (high), under low level of Cd $(0.1 \mathrm{mM})$, plant height showed increment (Nada et al., 2007).

Similarly, studies have also revealed the protective roles of trace elements in ameliorating toxic effects of heavy metals by protecting photosynthetic tissue and increasing antioxidant capacity (Zornoza et al., 2010; Tkalec et al., 2014). Pal'oveBalang et al. (2006) have shown that Mn-mediated amelioration of Cd toxicity was associated with a decreased Cd uptake. Apart from the beneficial role played by trace metals, there are some beneficial nutrients like selenium (Se), and silicon (Si) that also play a major role under heavy metal stress. Earlier, selenium (Se) was considered as toxic element but later on Schwarz and Foltz (1957) confirmed it to be an essential one. Studies on lettuce grown under $\mathrm{Pb}$ and $\mathrm{Cd}$ toxicity supplemented with Se showed a decrease in heavy metal accumulation as well as enhanced uptake of essential nutrients (He et al., 2004). Belokobylsky et al. (2004) and Feng and Wei (2012) have found that Se level up to $5 \mathrm{mg} \mathrm{L}^{-1}$ has beneficial effects on Spirulina platensis and $P$. vittata, respectively. Filek et al. (2008) have shown that exogenous application of Se alleviates toxic effects of $\mathrm{Cd}$ by enhancing the activities of antioxidant enzymes such as SOD, CAT, GPX, and APX. Several reports have revealed that appropriate dose of Se can protect plants against damage by heavy metals such as $\mathrm{Hg}$, $\mathrm{Pb}, \mathrm{Cd}, \mathrm{Cr}$, and Sb (Khattak et al., 1991; Shanker et al., 1996; Belokobylsky et al., 2004; He et al., 2004; Feng et al., 2011). Role of Si under heavy metal stress is also well established (Singh et al., 2011b; Dragišić Maksimović et al., 2012; Tripathi et al., 2012). Study by Song et al. (2009) has shown that supplementation of Si under Cd stress decreased an uptake and root to shoot translocation of $\mathrm{Cd}$ as well as enhanced the activities of enzymes of the defense machinery in B. chinensis. Similarly, study by Bharwana et al. (2013) revealed that $\mathrm{Si}$ application reduces $\mathrm{Pb}$ uptake and enhances the activities of antioxidants viz., SOD, GPX, APX, and CAT.

The measurement of elemental composition and their changes as a response to some stimuli in living organisms comes under the study of ionomics. Alteration in ionome could be direct or indirect. Direct one includes the changes in nutrient level in soil or due to impairment of ion transporter, whereas indirect changes might be due to changes in cell wall structure (Salt et al., 2008). Heavy metals due to their interaction with nutrient elements affect the uptake and distribution of these elements and may result in deficiency of minerals thus affecting the growth. Sarwar et al. (2010) suggested that Cd affects the permeability of plasma membrane and thus interferes with the nutrient uptake. However, there exists both antagonistic as well as synergistic interaction between heavy metals and micronutrient uptake, which could be due to differences in plant species and nutrient concentration. Likewise, a study by Cataldo et al. (1983) reported antagonistic interaction between $\mathrm{Cd}$ and $\mathrm{Fe}, \mathrm{Zn}, \mathrm{Cu}$, and $\mathrm{Mn}$ in soybean plants, whereas Nan et al. (2002) reported synergistic interaction between $\mathrm{Cd}$ and $\mathrm{Zn}$ in wheat and corn. In a study by Yang et al. (1998), decreased accumulation of $\mathrm{Fe}, \mathrm{Mn}$, and $\mathrm{Cu}$ in ryegrass, maize, cabbage, and white clover was observed after $\mathrm{Cd}$ exposure, whereas there was increased $\mathrm{P}$ accumulation. Similarly, Cui et al. (2008) reported decrease in Fe and Zn uptake in rice after $\mathrm{Cd}$ treatment in hydroponic system. A study by Safarzadeh et al. (2013) determined the effect of different doses (0, 45, and $90 \mathrm{mg} \mathrm{kg}$ soil) of $\mathrm{Cd}$ on uptake of $\mathrm{Fe}, \mathrm{Zn}, \mathrm{Cu}$, and $\mathrm{Mn}$ in seven rice cultivar and reported decrease in $\mathrm{Zn}, \mathrm{Fe}, \mathrm{Mn}$, and $\mathrm{Cu}$ uptake. Not only the uptake decreased but also there was decrease in the translocation of these minerals as $\mathrm{Cu}$ and $\mathrm{Fe}$ contents found to be greater in roots than in shoots that indicate toward impairment of ions transporters.

Similar to Cd, As has also been reported to influence nutrient uptake and their distribution in plants. Meharg and HartleyWhitaker (2002) reported As-induced decrease in P uptake is due to chemical similarity between $\mathrm{P}$ and arsenate and due to which arsenate enters the plant via the phosphate transport systems. However, the concentration of As also plays an important role in P uptake. Burló et al. (1999) reported higher uptake of $\mathrm{P}$ at lower level of As in tomato plants. Similarly, Carbonell et al. (1998) reported increased P uptake in tomato plant when exposed to low level of As. As not only influences $\mathrm{P}$ uptake but also affects the uptake of other nutrients like $\mathrm{N}$, P, K, Ca, etc. A study by Carbonell-Barrachina et al. (1997) observed increased concentration of $\mathrm{N}, \mathrm{P}, \mathrm{K}, \mathrm{Ca}$, and $\mathrm{Mg}$ in $P$. vulgaris L. plants when exposed to arsenite. Similarly, CarbonellBarrachina et al. (1994) reported decreased uptake of $\mathrm{K}, \mathrm{Ca}$, and $\mathrm{Mg}$ (macronutrinets), $\mathrm{B}, \mathrm{Cu}, \mathrm{Mn}$, and $\mathrm{Zn}$ (micronutrinets) in Lycopersicum esculentum Mill. The effect of As concentration on nutrient level of hyperaccumulator $P$. vittata $\mathrm{L}$. had also been studied by Tu and Ma (2005), and the authors reported that both micro- and macronutrients were in the range of normal concentration as in non-hyperaccumulators. However, there was enhancement in $\mathrm{P}$ and $\mathrm{K}$ contents in the fronds of $P$. vittata $\mathrm{L}$. at lower level of As. They reported molar ratio of $\mathrm{P} / \mathrm{As}$ to be 1.0 in fronds of $P$. vittata L., which is the threshold value for normal growth of plants.

Heavy metal ions such as $\mathrm{Cu}^{+2}, \mathrm{Zn}^{+2}, \mathrm{Mn}^{+2}$, and $\mathrm{Fe}^{+2}$ are essential for plant metabolism but when they are present in excess amount become highly toxic. For instance, $\mathrm{Zn}$ and $\mathrm{Mn}$ when present in excess impairs growth and compete with Fe. Excess Fe in the plant system participates in the fenton reaction, thereby creating a condition of oxidative stress (Williams and Pittman, 2010; Shanmugam et al., 2011). In order to avoid toxicity induced by mineral elements and trace elements, these are chelated by low molecular weight compounds and sequestrated in vacuoles or excluded to extracellular spaces by transporters situated in the tonoplast or plasma membrane, which plays central role in maintaining metal homeostasis under safe limit. These transporters belong to (1) $\mathrm{P}_{1 \mathrm{~B}}$-ATPase or CPx-type ATPase, (2) Cation Diffusion Facilitator (CDF) also known as Metal Tolerance Proteins (MTPs), (3) Natural Resistance-Associated Macrophage Proteins (NRAMPs), and (4) ZRT-IRT-like Protein (ZIP) transporters. 


\section{$\mathrm{P}_{1 \mathrm{~B}}$-ATPases (also Known as Heavy Metal ATPases: HMAs)}

$\mathrm{P}_{1 \mathrm{~B}}$-ATPases (also known as Heavy Metal ATPases: HMAs) are found in a wide range of organisms ranging from prokaryotes to eukaryotes including yeasts, insect, mammals, and plants. Being energized by ATP hydrolysis, they translocate heavy metals (Zn, $\mathrm{Co}, \mathrm{Cu}, \mathrm{Cd}$, and $\mathrm{Pb}$ ) out of cytoplasm (to plasma membrane and into vacuole) and thus play important roles in their transport, compartmentalization, and detoxification (Williams et al., 2000; Grennan, 2009). HMA members (HMA2, HMA3, and HMA4) export $\mathrm{Zn}$ and $\mathrm{Cd}$. For instance, HMA4 protein that plays a role in nutrition and transport of $\mathrm{Zn}$ from root to shoot also protects plants from Cd via its efflux (Mills et al., 2005). Hussain et al. (2004) demonstrated that though HMA2 and HMA4 are essential for $\mathrm{Zn}$ homeostasis in Arabidopsis, double mutants of HMA2 and HMA4 (hma2 and hma4) exhibited increased sensitivity of plant to $\mathrm{Cd}$, suggesting that they may also play a role in $\mathrm{Cd}$ detoxification. Similarly, loss of function in HMA2 and HMA4 has been shown to increase $\mathrm{Cd}$ sensitivity in Arabidopsis under phytochelatins deficient, cad1-3 as well as CAD1 backgrounds (Wong and Cobbett, 2009). A recent study on 349 wild varieties of A. thaliana with combined approach of genomewide association mapping, linkage mapping, and transgenic complementation revealed that HMA3 is solely responsible for variation in amount of $\mathrm{Cd}$ accumulated. Varieties with high $\mathrm{Cd}$ accumulation indicate toward reduced HMA3 function (Chao et al., 2012). Similarly, Song et al. (2014) found expression of Ctype ATP-binding cassette $(\mathrm{ABC})$ transporter (OsABCC) family in Oryza sativa and reported its involvement in detoxifying and reducing As accumulation in grains. They reported higher expression of these transporters under higher level of As.

\section{Cation Diffusion Facilitators (CDFs) or Metal Tolerance Proteins (MTPs)}

Cation Diffusion Facilitators (CDFs), also known as Metal Tolerance Proteins (MTPs) family, were first reported by Nies and Silver (1995) and found in diverse group of organisms such as bacteria, fungi, animals, and plants. Members of this family are involved in cellular heavy metals homeostasis with principal selectivity for $\mathrm{Zn}^{2+}, \mathrm{Mn}^{2+}$, and $\mathrm{Fe}^{2+}$ (Podar et al., 2012). Despite their specificities for $\mathrm{Zn}^{2+}, \mathrm{Mn}^{2+}$, and $\mathrm{Fe}^{2+}$, many CDFs may also transport other heavy metals such as $\mathrm{Co}^{2+}, \mathrm{Ni}^{2+}$, and $\mathrm{Cd}^{2+}$ (Ricachenevsky et al., 2013). CDFs transporters are involved in heavy metals efflux from the cytoplasm either to the extracellular space or into the organelles (Haney et al., 2005; Peiter et al., 2007; Ricachenevsky et al., 2013). Twelve MTP genes have been recognized so far in A. thaliana and 10 in O. sativa (Gustin et al., 2011). In A. thaliana, the first CDF gene was characterized as the Zinc Transporter 1 gene (ZAT1) and later renamed as METAL TOLERANCE PROTEIN 1 (AtMTP1) (van der Zaal et al., 1999; Delhaize et al., 2003). The AtMTP1 gene is expressed constitutively in roots as well as in shoots, and when overexpressed in Arabidopsis, it enhances $\mathrm{Zn}$ tolerance (van der Zaal et al., 1999). However, RNA interference (RNAi)-mediated silencing (Desbrosses-Fonrouge et al., 2005) or T-DNA insertion mutation (Kobae et al., 2004) of this gene increases Zn sensitivity, indicating its important role in regulation of $\mathrm{Zn}$ homeostasis.
In A. halleri, a Zn hyperaccumulator plant, AhMTP1 gene is believed to have a role in $\mathrm{Zn}$ hypertolerance (Shahzad et al., 2010). Unlike AtMTP1 gene, AtMTP3 is expressed predominantly in roots and reported to be engaged in maintenance of $\mathrm{Zn}$ homeostasis by excluding $\mathrm{Zn}$ under $\mathrm{Zn}$ oversupply (Arrivault et al., 2006). Another member of MTPs family, AtMTP11, has been reported to transport as well as provide Mn tolerance (Delhaize et al., 2007; Peiter et al., 2007). In rice, an ortholog of MTPs, OsMTP1, has been characterized and supposed to be located on chromosome 5 and highly expressed in mature leaves and stem (Lan et al., 2012; Yuan et al., 2012).

Menguer et al. (2013) demonstrated that OsMTP1 gene localized on tonoplast, and when heterologously expressed in the yeast-mutant $z r c 1$ and cot1, complemented $\mathrm{Zn}$ hypersensitivity. Besides, its expression also alleviated Co sensitivity, rescued Fe hypersensitivity of the $c c c 1$ mutant, and restored growth of the Cd-hypersensitive mutant $y c f 1$, indicating potential role of this gene in possible biotechnological applications, such as bio fortification and phytoremediation.

\section{Natural Resistance-Associated Macrophage Proteins (NRAMPs) Transporters}

Nramp is a highly conserved family of integral membrane proteins that are conserved in different species and located in the plasma membrane of root apical cells (Simões et al., 2012). They are involved in proton-coupled active transport of various heavy metals $\left(\mathrm{Fe}^{2+}, \mathrm{Zn}^{2+}, \mathrm{Mn}^{2+}, \mathrm{Co}^{2+}, \mathrm{Cd}^{2+}, \mathrm{Cu}^{2+}, \mathrm{Ni}^{2+}\right.$, and $\left.\mathrm{Pb}^{2+}\right)$ in wide range of organisms including bacteria, fungi, animals, and plants (Hall and Williams, 2003; Cailliatte et al., 2009). However, the physiological role of NRAMP was primarily related with $\mathrm{Fe}$ and to a lesser extent for $\mathrm{Mn}$ transport (Cailliatte et al., 2009). AtNRAMP1 and 6, forms the first group, and AtNRAMP2-5 constitute the second group (Mäser et al., 2001). Of these, AtNRAMP1, 3, 4, and 6 have been shown to encode functional plant heavy metal transporters (Krämer et al., 2007; Cailliatte et al., 2009). Yeast mutants defective in heavy metals uptake have been utilized to investigate transport specificities of plant Nramps. Study revealed that AtNRAMP1 can complement the fet $3 f e t 4$ yeast mutant that is defective in both low and highaffinity Fe transporters, whereas overexpression of AtNRAMP1 in Arabidopsis increases plant resistance to toxic Fe concentrations (Curie et al., 2000). Furthermore, AtNRAMP3 and AtNRAMP4 have been shown to mediate the remobilization of Fe from the vacuolar store and are essential for seed germination under low Fe conditions (Thomine et al., 2003; Lanquar et al., 2005), indicating a role of Nramps in Fe homeostasis.

Since the roles of NRAMPs family proteins were previously related with $\mathrm{Fe}$ uptake and transport in biological systems, however, increasing numbers of studies indicated that members of this family have wide range of specificities for pumping cations inside and/or outside the cell. Cailliatte et al. (2010) demonstrated that NRAMP1, localized on plasma membrane, restores the capacity of the iron-regulated transporter1 (a ZIP family metal transporter) mutant to take up $\mathrm{Fe}$ and $\mathrm{Co}$, indicating that NRAMP1 has a broad selectivity for heavy metals invivo. An AtNRAMP4 homolog, TjNRAMP4, was cloned from the Ni hyperaccumulator Thlaspi japonicum, and its expression 
increased $\mathrm{Ni}^{2+}$ sensitivity of wild-type yeast due to elevated $\mathrm{Ni}$ accumulation, indicating that this protein might transport $\mathrm{Ni}$ into the cytoplasm (Mizuno et al., 2005). Besides regulating uptake and distribution of essential heavy metals, Nramps have also been found to be involved in the transport of non-essential heavy metals. In Arabidopsis, AtNRAMP3 disruption increases $\mathrm{Cd}^{2+}$ resistance, whereas overexpression of this gene confers increased $\mathrm{Cd}^{2+}$ sensitivity, indicating that it plays a role in $\mathrm{Cd}^{2+}$ transport and sensitivity in plant (Thomine et al., 2000; Mäser et al., 2001).

A O. sativa Nrat1 (OsNrat1) gene, a Nramp aluminum transporter and localized at all cells of root tips, when expressed in yeast transports only $\mathrm{Al}^{3+}$ but not the $\mathrm{Mn}, \mathrm{Fe}$, and $\mathrm{Cd}$, indicating that this transporter gene specifically transports only Al (Xia et al., 2011). Furthermore, in knockout of Nrat1, Al sensitivity increased, whereas in wild type, its expression is upregulated by $\mathrm{Al}$ in root that is believed to be required for a prior step of final $\mathrm{Al}$ detoxification through sequestration of $\mathrm{Al}$ into vacuoles. Study of Cailliatte et al. (2009) demonstrated that Arabidopsis transgenic plants overexpressing AtNRAMP6 gene were hypersensitive to $\mathrm{Cd}$, although plant $\mathrm{Cd}$ content remained unchanged, thereby indicating that modification in expression pattern of AtNRAMP6 affects distribution and availability of Cd within the cell. However, Sano et al. (2012) have shown that Nicotiana tabacum NRAMP1 gene (NtNRAMP1), a plasma membrane transporter, when overexpressed in tobacco BY-2 cells increases resistance of the cells to both $\mathrm{Fe}$ and $\mathrm{Cd}$, and suggested that NtNRAMP1 moderates Fe-uptake and prevents toxicity resulting from excess $\mathrm{Fe}$ or $\mathrm{Cd}$ application. Tiwari et al. (2014) also demonstrated that OsNRAPM1, localized on plasma membrane of endodermis and pericycle cell, when expressed in Arabidopsis provides tolerance against As and Cd with their enhanced accumulation in root and shoot, and proposed that modification in this gene may be helpful in reducing the risk of food chain contamination by these toxic heavy metals. These studies clearly indicate that NRAMP genes are able to encode multi-specific heavy metals transporters. In recent years, a new Nramp5 belonging to rice (Os Nramp5) has been characterized, which is responsible for accumulation of $\mathrm{Mn}$ in rice and has been reported to encode proteins localized on plasma membrane, thus suggesting that Nramp5 is a major transporter responsible for transport of Mn and Cd (Sasaki et al., 2012). To gain deep insights into the roles of NRAMP genes transporter in heavy metals uptake and homeostasis in plants, a more systematic characterization of the different members of the NRAMP family is further required.

\section{ZRT, IRT-Like Proteins (ZIP) Transporters}

Members of the ZIP family named on the first member identified ZRT IRT- like Protein in Arabidopsis, expressed in roots of iron deficient plants and found to be capable of transporting various heavy metals such as $\mathrm{Fe}, \mathrm{Zn}, \mathrm{Mn}, \mathrm{Cd}$ and $\mathrm{Ni}$ within cellular systems (Mäser et al., 2001). The key feature of the ZIP family is that these proteins can transport heavy metals from the extracellular space or from organelles lumen into the cytoplasm. In Arabidopsis, 15 genes viz. ZIP1-12, IRT1, IRT2, and IRT3 of the ZIP family are reported (Milner et al., 2013). Among these members, AtIRT1, AtIRT2, and AtIRT3 transporters are well characterized, with AtIRT1 being the most studied (Eide et al., 1996; Lin et al., 2009; Vert et al., 2009) for their involvement in regulation of $\mathrm{Zn}$ and Fe homeostasis in plants. Rest of the ZIP family members has been studied for their membrane localization and heavy metals they transport into or outside of a specific organelle (Milner et al., 2013). In a model legume Medicago truncatula, six ZIP family transporters MtZIP1, MtZIP3, MtZIP4, MtZIP5, MtZIP6, and MtZIP7 have been tested for their ability to complement yeast heavy metals uptake mutants, and each family member was able to rescue the growth of $\mathrm{Zn}, \mathrm{Mn}$, and Fe uptake mutants, indicating their function in heavy metals transport (López-Millán et al., 2004).

Apart from the abovementioned transporters, recently another transporter arsenate reductase (ACR) has been characterized in yeast Saccharomyces cerevisiae, a model system for As resistance. It was reported that a $4.2-\mathrm{kb}$ region conferred arsenite (AsIII) resistance in S. cerevisiae; they found three ACR genes, namely ACR1, ACR2, and ACR3 (Bobrowicz et al., 1997). These authors also reported that ACR1 regulates ACR2 and ACR3 by transcriptional factor and any loss in ACR1 function yeast conferred arsenite and arsenate hypersensitivities (Bobrowicz et al., 1997; Ghosh et al., 1999). Later on, Landrieu et al. $(2004 \mathrm{a}, \mathrm{b})$ reported that ACR2 represents arsenate reductase that showed homology to yeast ASCR2 (ScACR2). Similarly, Ellis et al. (2006) reported other transporter PvACR2 from P. vittata and OsACR2.1 and OsACR2.3 from O. sativa (Duan et al., 2007). Earlier, ACR2 (called as CDC25) was thought to be involved in As metabolism in A. thaliana. Recent studies on $A$. thaliana have revealed the involvement of new arsenate reductase (ACR), namely HAC1 (Chao et al., 2014) or ATQ1 (Sánchez-Bermejo et al., 2014). Chao et al. (2014) reported that loss of function of HAC1 in A. thaliana resulted in decreased As accumulation in roots, and thus, there was diminished As efflux to external medium. Another transporter, OsABCC1 localized in phloem cells of $O$. sativa, has been reported to be involved in sequestration of As to vacuole (Song et al., 2014). However, in anaerobic paddy fields, As (mainly Arsenite) uptake is regulated by transporters of $\mathrm{Si}$, namely Lsil (low silicon 1; influx transporter) and Lsi2 (low silicon 2; efflux transporters) (Ma et al., 2008). Apart from these transporters, there are some other transporters as well that transfer arsenate and arsenite. Likewise, a transporter from $P$. vittata, PvACR3 has been reported to compartmentalize As into the vacuoles and loss in its function results in As hypersensitivity (Indriolo et al., 2010).

\section{Transcriptomics}

Investigations on the basic mechanisms of heavy metal tolerance and adaptation are the area of great scientific interest and an intensive research. Various stressors induce an expression of a set of genes in plants (Nakashima et al., 2009).

At molecular level, the regulation of gene expression is very important for the biological processes, which determines the fate of plant development as well as tolerance to heavy metal stress. Stressors trigger large number of genes and several proteins in order to link the signaling pathways that confer stress tolerance (Umezawa et al., 2006; Valliyodan and Nguyen, 
2006; Manavalan et al., 2009; Tran et al., 2010). These genes are classified into two groups: the regulatory genes and the functional genes (Tran et al., 2010). The genes of regulatory group encode various transcription factors (TFs), which can regulate various stress-responsive genes cooperatively and/or separately and thus, constitute a gene network. However, the genes of functional group encode metabolic compounds such as amines, alcohols, and sugars, which play a crucial role in heavy metal stress tolerance. The TFs, which are reported to be master regulators, control an expression of gene clusters and usually members of multigene families. Studies reveal that a single TF can control the expression of many target genes via specific binding of the TF to the cis-acting element in the promoters of its target genes (Wray et al., 2003; Nakashima et al., 2009). Most of the TFs contain a DNA-binding domain that interacts with cis-regulatory elements in the promoters of its target genes and via a proteinprotein interaction domain that helps in oligomerization of TFs with other regulators (Wray et al., 2003; Shiu et al., 2005). This type of transcriptional regulatory system is referred as "regulon" (Nakashima et al., 2009). Various TFs families such as AREB/ABF, MYB, AP2/EREBP, WRKY, bHLH, bZIP, MYC, HSF, DREB1/CBF, NAC, HB, ARID, EMF1, CCAAT-HAP2, CCAATDR1, CCAAT-HAP3, CCAAT-HAP5, C2H2, C3H, C2C2-Dof, C2C2-YABBY, C2C2-CO-like, C2C2-Gata, E2F-DP, ABI3VP1, ARF, AtSR, CPP, E2F-DP, SBP, MADS, TUB, etc. are known to influence stress response in plants (Singh et al., 2002; Shiu et al., 2005; Shameer et al., 2009). LeDuc et al. (2006), in a transcriptome analysis on plants, reported that plants treated with heavy metals could induce transcription factors that regulate corresponding transcriptional processes.

Liang et al. (2013) reported first FER regulatory gene involved in Fe uptake in tomato, and the functional analog of FER is FER-like Deficiency Induced Transcripition Factor (FIT) that has been conferred to play an important role under Fe deficiency in Arabidopsis (Yuan et al., 2005). In addition to this, there are several other subgroups of bHLH family viz., AtbHLH38, AtbHLH39, AtbHLH100, and AtbHLH101 that have been shown to be upregulated under Fe deficiency in roots and leaves of Arabidopsis (Wang et al., 2007; Yuan et al., 2008). Later, several researchers proposed that AtbHLH38 or AtbHLH39 interacts with FIT and forms heterodimers and directly activates transcription factors for ferric chelate reductase and ferrous transporters, which are the two major genes regulating Fe uptake under deficient condition (Varotto et al., 2002; Vert et al., 2002; Yuan et al., 2008). In Arabidopsis, IRT1 has been reported to be the most essential ferrous transporter. Beside transporting $\mathrm{Fe}$, it can also transport $\mathrm{Zn}, \mathrm{Mn}, \mathrm{Co}, \mathrm{Ni}$, and $\mathrm{Cd}$, and thus, these metals get accumulated under Fe deficiency (Vert et al., 2002; Schaaf et al., 2006). A recent study by Wu et al. (2012) in Arabidopsis revealed that expression of FIT with AtbHLH38 or AtbHLH39 further activates expression of several other transporters viz., HMA3, (MTP3), Iron Regulated Transporter2 (IRT2) that play regulatory role in maintaining Fe content under $\mathrm{Cd}$ exposure.

Transcriptome analysis in A. thaliana and B. juncea exposed to $\mathrm{Cd}$ stress has revealed the induction of basic region leucine zipper (bZIP) and zinc finger transcription factors (Ramos et al., 2007). ERF1 and ERF5, two transcription factors belonging to AP2/ERF superfamily (characterized by AP2/ERF domain; Nakano et al., 2006), have been reported to be induced when A. thaliana was exposed to Cd (Herbette et al., 2006). Similar induction of TFs has been reported in A. halleri under Cd stress (Weber et al., 2006). Differential expression of ERF factors under $\mathrm{Cd}$ indicates toward their responses to various levels of $\mathrm{Cd}$ stress. A study by Nakashima and Yamaguchi-Shinozaki (2006) reported down-regulation of dehydration-responsive elementbinding protein (DREB) transcription factor (involved in cold and osmotic stress responsive genes) in roots of A. thaliana under heavy metal treatment and suggested it could be acclimation response and DREB might have helped in normalizing osmotic potential, so that flow of heavy metal-contaminated water could be reduced, thus helping plants to avoid toxic effects of heavy metal. Therefore, acquiring a deep knowledge of the interrelated mechanisms, which regulate the expression of these genes, is a crucial issue in plant biology and necessary to generate genetically improved crop plants for extreme environments like heavy metal stress (Umezawa et al., 2006; Valliyodan and Nguyen, 2006; Nakashima et al., 2009). Summary of an involvement of TFs in conferring heavy metal and other abiotic stresses tolerance is given in Table 2.

\section{Mitogen-Activated Protein Kinase MAPK Cascade}

MAPK cascade are activated in response by plants when exposed to heavy metal stresses. This cascade has its significance in activation of signal transduction pathway used in hormone synthesis (Jonak et al., 2002). This cascade involves three kinases viz., MAPK kinase kinase (MAPKKK), the MAPK kinase (MAPKK), and the MAPK, which are activated by phosphorylation process. The finally formed phosphorylated MAPK cascade phosphorylates substrates in cells including transcription factors in nucleus. Therefore, MAPK regulates the transduction of information downstream. Jonak et al. (2004) have shown four isoforms of MAPK that are activated under $\mathrm{Cu}$ or $\mathrm{Cd}$ stress in Medicago sativa. All these pathways finally lead to regulation of transcription factors that in turn activate genes for activation of metal transporters, biosynthesis of chelating compounds, and other defensing compounds.

\section{Proteomics}

Proteomics is a well-established technique in the post-genomic era (Liu et al., 2013). Proteomics deals with the study of largescale expression of proteins in an organism encoded by its genome (Anderson and Anderson, 1998). Proteomics not only serves as a powerful tool for describing complete protein changes in any organisms but it can also be used to compare variation in protein profiles at organ, tissue, cell and organelle levels under various stress conditions including heavy metal stress (Ahsan et al., 2009). Although genomic analysis has enhanced our understanding regarding plants' response to heavy metal toxicity, transcriptomic changes in the genome are not always reflected at protein level (Gygi et al., 1999; Hossain and Komatsu, 2013). For instance, putative $\mathrm{Zn}$ and $\mathrm{Mg}$ transporter protein $\mathrm{MHX}$ was more abundant in Arabidopsis even though its corresponding transcript level was not different (Elbaz et al., 2006). This suggests that transcription of any gene is not a guaranty 
TABLE 2 | Summary of transcription factors (TFs) whose overexpression in plants confers heavy metal stress tolerance.

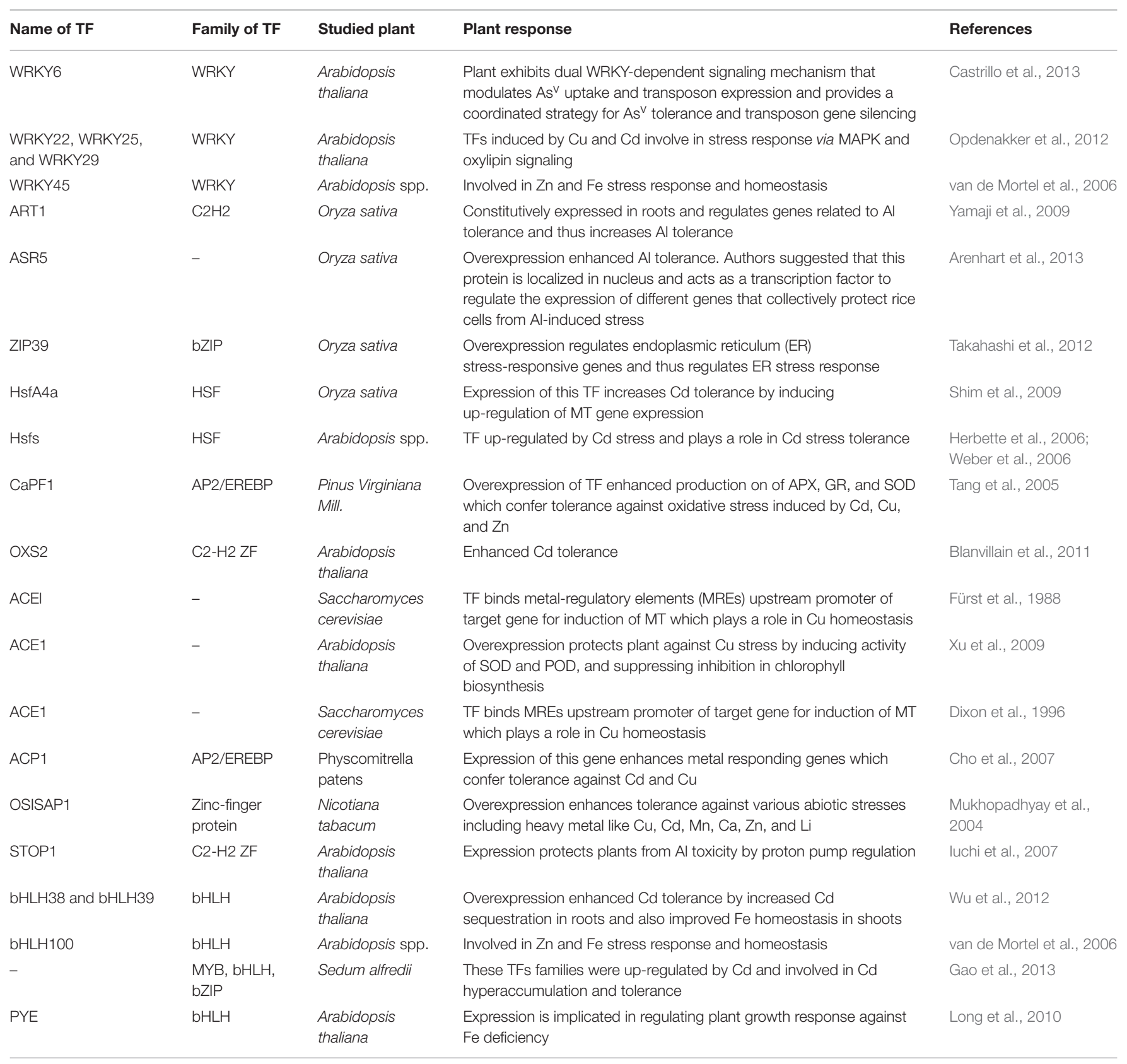

that gene would be translated into a functional protein. This may occur due to the potential impact of post-transcriptional and translational modifications, protein folding, stability and localization, protein-protein interactions, which are considered important determinants of a protein function (Dalcorso et al., 2013 b). Therefore, depth analyses of proteomics offer a new platform for identifying target proteins, which take part in heavy metal detoxification, and in studying complex biological processes and interactions among the possible pathways that involve a network of proteins (Ahsan et al., 2009).

Furthermore, it is known that proteins directly take part in plant stress responses, and plant adaptations to heavy metal stress are always accompanied with deep proteomic changes. Therefore, technique of proteomics can be exploited for deciphering the possible relationships between proteins abundance and plant stress adaptation. It can contribute to better understanding of physiological mechanisms under heavy metal stress such as perception of stress and further signaling cascade that leads to changes in the expression of huge numbers of genes at transcriptional level and in metabolite profile, which could be used for an acquisition of an enhanced plant tolerance under heavy metal toxicity (Kosová et al., 2011). Studies have revealed that an abundance of defense proteins was increased for scavenging of ROS, and molecular chaperones play a role 
in re-establishing the conformation of a functional protein that contributes in helping heavy metal stressed plants to maintain the redox homeostasis (Zhao et al., 2011; Sharmin et al., 2012; Wang et al., 2012). Under heavy metal stress, modulations of various metabolic pathways occur such as photosynthesis, respiration, nitrogen metabolism, sulfur metabolism, etc. particularly in photosynthesis and mitochondrial respiration that help stressed plants to produce more reducing power such as NADPH, $\mathrm{NADH}$, and $\mathrm{FADH}_{2}$ and assimilatory power ATP to compensate high energy demand of heavy metal-challenged plants (Hossain and Komatsu, 2013). For example, an increased abundance of RUBISCO large sub unit (LSU)-binding proteins, oxygenevolving enhancer protein 1 and 2, $\mathrm{NAD}(\mathrm{P}) \mathrm{H}$-dependent oxidoreductase, and photosystem I and II-related proteins is an adaptive feature to withstand heavy metal stress (Semane et al., 2010). The cellular mechanism of stress sensing and further transduction of signals into the cell appear to be the first reactions in the plant cell against heavy metal. Furthermore, an intracellular communication of stress signals plays a fundamental role in signal transduction pathways under stress, which ultimately activate defense-related genes and thus signaling cascades (Hossain et al., 2012c). Therefore, to decipher an underlying molecular mechanism of alterations in the protein signature of a plant cell in order to withstand stress, a deep study on the cellular as well as organelle proteomics would be of great importance in developing heavy metal-tolerant crops. Alterations in protein profile under heavy metal stress, which could be utilized for developing heavy metal-tolerant plants, are given in Table 3.

Apart from inducing synthesis of amino acids (proline and histidine), amines, organic acids, and plant antioxidant $\alpha$-tocopherol and glutathione, some nitrogen containing metabolites like some peptides (phytochelatins, metallothioneins, and ferritins) have been reported to play an important role under heavy metal stress. In the following section, we will discuss about the roles of peptides in heavy metal tolerance.

\section{PEPTIDES}

Phytochelatins (PCs) have been the best-characterized chelators in plant systems. PCs belong to a family of metal-binding protein having general structure (c-Glu-Cys) $n$ Gly $(n=2-$ 11) (Cobbett and Goldsbrough, 2002). These are synthesized by the transpeptidation of the $\gamma$-Glu-Cys moiety of GSH, and the transpeptidation reactions are carried out by enzyme named phytochelatin synthase (PCS). It has been reported that PCS were activated under heavy metal exposure (Rauser, 1995; Cobbett, 2000), and similar PC synthase activity has been observed in several other crops (Klapheck et al., 1995; Chen et al., 1997; Mishra et al., 2009a). Loeffler et al. (1989) confirmed that metals induce PC synthesis, in in-vivo as well as in in-vitro cultures, and were continuously synthesized until activated metal ions chelated. Haag-Kerwer et al. (1999) reported induction of PCs in B. juncea after the accumulation of $\mathrm{Cd}$ in the cells, and thus plays important role in detoxifying heavy metals (Hirata et al., 2005). Due to the presence of thiol group, they have the capability of chelating metals and forming complexes (Cobbett, 2000), which are then sequestrated in the vacuole. From the preceding discussion, it is clear that chelation by PCs is not a simple process but involves a complex molecular mechanism, where firstly, the PCS gets activated by metal ion and biosynthesis of PCs takes place; secondly, formation of complexes and sequestration in vacuole; thirdly, more complexation with the sulfides or organic acids in the vacuole, and finally detoxified. Besides detoxifying heavy metals, PCs also play a major role in metal ion homeostasis and thus regulating the metal ion availability in plant cells (Guo et al., 2008b).

Like PCs, metallothioneins (MTs) are synthesized and activated under heavy metal toxicity. They belong to a family of low molecular weight protein having cysteine-rich metal binding peptide. Due to the presence of mercaptides, they have the ability of binding metal ions. Metal-binding activities of MTs have been expressed in Escherichia coli in presence of $\mathrm{Cd}, \mathrm{Zn}$, and $\mathrm{Cu}$ (Tommey et al., 1991). In addition, Zhou and Goldsbrough (1994) reported restoration in Cu tolerance ability of MT-deficient yeast strains, when provided with the Arabidopsis MTs. Similar to this, Zhigang et al. (2006) conferred increased tolerance of $A$. thaliana to $\mathrm{Cd}$ and $\mathrm{Cu}$, when ectopically substituted with $B$. juncea MT. Moreover, comparative study of mutant and wild-type $A$. thaliana has clearly revealed that MT mutant was hypersensitive to $\mathrm{Cd}$ and accumulated much lower amount of Cd than wild type, thus conferring role of MTs in both heavy metal tolerance as well as accumulation (Zimeri et al., 2005). In terms of transcript amount, expression of MT genes varies during different developmental stages of plant as well as under varying environmental condition (Rauser, 1999). Beside, chelating metal ions MTs can also catalyze antioxidant protection mechanism as well as plasma membrane repair (Hamer, 1986).

Ferritins are other multimeric proteins that could accumulate iron atom (Harrison and Arosio, 1996). However, animal ferritins have been reported to store other metals like $\mathrm{Cu}, \mathrm{Zn}, \mathrm{Cd}$, etc., whereas plants ferritin could store only Fe. These are synthesized in plants when there is excess $\mathrm{Fe}$ in the surroundings and thus represents first-line defense against Fe-induced oxidative stress (Ravet et al., 2009). These are not only involved in storing or releasing $\mathrm{Fe}$ but also involved in scavenging free reactive iron (Ravet et al., 2009).

\section{PLANT GROWTH HORMONES}

In spite of five classical plant hormones, i.e., gibberellins (GAs), cytokinins (CKs), auxins, abscisic acid (ABA), and ethylene, jasmonate (JA), brassinosteroids (BR), and salicylic acid (SA) are also well known for regulating many physiological processes and heavy metal stress tolerance (Freeman et al., 2005b; Gangwar et al., 2010; Gangwar and Singh, 2011; Peleg and Blumwald, 2011; Choudhary et al., 2012a,b; Vriet et al., 2012). Furthermore, it is also expected that some more growth hormones are yet to be discovered in future. In laboratory as well as filed studies, two strategies have been used for plant hormone-mediated increase in stress tolerance as well as crop yield. These strategies include exogenous application of plant hormones and genetic manipulation of their endogenous contents. Both approaches have given promising results for increasing crop yield and 
TABLE 3 | Summary of heavy metal-induced changes in protein expressions and their potential uses in developing heavy metal tolerant plants.

\begin{tabular}{|c|c|c|c|c|c|}
\hline Metal & $\begin{array}{l}\text { Technique(s) } \\
\text { used }\end{array}$ & $\begin{array}{l}\text { Plant } \\
\text { species }\end{array}$ & Alterations in protein(s) expression profile & Plant response & References \\
\hline \multirow[t]{6}{*}{$\mathrm{Cd}$} & $\begin{array}{l}\text { 2DE, MALDI- } \\
\text { TOF-MS, } \\
\text { LC-ESI- } \\
\text { QTOF-MS }\end{array}$ & $\begin{array}{l}\text { Arabidopsis } \\
\text { thaliana }\end{array}$ & $\begin{array}{l}\text { 1100 Spots reported, } 41 \text { spots showed significant } \\
\text { changes including phytochelatins, } \\
\text { glutathione-S-transferases, ATP sulfurylase, glycine } \\
\text { hydroxymethyl transferase, trehalose-6-phosphate } \\
\text { phosphatase }\end{array}$ & $\begin{array}{l}\text { Alterations in these proteins in } \\
\text { plant roots help to withstand } \mathrm{Cd} \\
\text { stress via modulating } \mathrm{S} \\
\text { assimilation }\end{array}$ & Roth et al., 2006 \\
\hline & $\begin{array}{l}\text { 2DE, MALDI- } \\
\text { TOF/TOF- } \\
\text { MS }\end{array}$ & $\begin{array}{l}\text { Phytolacca } \\
\text { americana }\end{array}$ & $\begin{array}{l}32 \text { Proteins are differentially expressed, } 14 \text { enhanced, and } \\
11 \text { reduced under Cd treatment. Major changes were in } \\
\text { photosynthetic pathway, S and GSH metabolism, } \\
\text { transcription, translation and chaperones, } 2 \\
\text { cys-peroxiadse and oxido-reductases proteins }\end{array}$ & $\begin{array}{l}\text { These alterations play a key role } \\
\text { in enhancing Cd hypertolerance } \\
\text { in plant }\end{array}$ & Zhao et al., 2011 \\
\hline & $\begin{array}{l}\text { 2DE, MALDI- } \\
\text { TOF/TOF- } \\
\text { MS }\end{array}$ & $\begin{array}{l}\text { Arabis } \\
\text { paniculata }\end{array}$ & $\begin{array}{l}18 \text { Proteins differentially expressed upon Cd treatment } \\
\text { which were mainly related with photosynthetic pathway } \\
\text { and antioxidant defense system such as } \\
\text { ribulose-5-phosphate 3-epimerase (RPE), RuBisCO } \\
\text { activase, Protein thylakoid formation } 1 \text { (THF1), Mn-SOD, } \\
\text { APX, GST }\end{array}$ & $\begin{array}{l}\text { Plant adopted alterations mainly } \\
\text { in antioxidative/xenobiotic } \\
\text { defense and hence exhibited } \\
\text { increased Cd tolerance }\end{array}$ & Zheng et al., 2011 \\
\hline & $\begin{array}{l}\text { 2-D DIGE, } \\
\text { MALDI- } \\
\text { TOF/TOF }\end{array}$ & Populus sp. & $\begin{array}{l}\text { A number of changes in the expression of proteins with } \\
\text { various functions were identified; in particular a decreased } \\
\text { abundance of oxidative stress regulating proteins, whereas } \\
\text { pathogenesis-related proteins showed a drastic increase in } \\
\text { abundance. Furthermore, a large number of proteins } \\
\text { involved in carbon metabolism showed a decrease in } \\
\text { abundance, while proteins involved in remobilizing carbon } \\
\text { from other energy sources were up-regulated }\end{array}$ & $\begin{array}{l}\text { Due to deep proteomic } \\
\text { changes, plant experienced } \\
\text { lesser negative impact of Cd on } \\
\text { physiological parameters and } \\
\text { hence plant showed Cd } \\
\text { tolerance }\end{array}$ & Kieffer et al., 2008 \\
\hline & $\begin{array}{l}\text { 2DE, MALDI- } \\
\text { TOF-MS }\end{array}$ & Oryza sativa & $\begin{array}{l}36 \text { Proteins either up-and/or down-regulated by } \mathrm{Cd} \\
\text { treatment. Most of the proteins were related to oxidative } \\
\text { stress and antioxidative system }\end{array}$ & $\begin{array}{l}\text { Antioxidative system related } \\
\text { proteins play a role in } \mathrm{Cd} \\
\text { tolerance }\end{array}$ & Lee et al., 2010 \\
\hline & 2DE & $\begin{array}{l}\text { Thlaspi } \\
\text { caerulescens }\end{array}$ & $\begin{array}{l}48 \text { Tentatively spots identified which represent core } \\
\text { metabolic functions, e.g., photosynthesis, nitrogen } \\
\text { assimilation, carbohydrate metabolism as well as putative } \\
\text { signaling and regulatory functions }\end{array}$ & $\begin{array}{l}\text { The possible roles of some of } \\
\text { the proteins were related with } \\
\text { metal accumulation and } \\
\text { tolerance }\end{array}$ & Tuomainen et al., 2006 \\
\hline \multirow[t]{3}{*}{ As } & $\begin{array}{l}\text { 2DE, MALDI- } \\
\text { TOF-MS }\end{array}$ & Oryza sativa & $\begin{array}{l}23 \text { Proteins up-regulated related with defense proteins like } \\
\text { S-adenosylmethionine synthetase (SAMS), GSTs, cysteine } \\
\text { synthase (CS), GST-tau, and tyrosine-specific protein } \\
\text { phosphatase proteins (TSPP), and an omega domain } \\
\text { containing GST }\end{array}$ & $\begin{array}{l}\text { SAMS, CS, GSTs, and GR } \\
\text { presumably work synchronously } \\
\text { and GSH plays a key role in } \\
\text { protecting rice roots against As } \\
\text { stress }\end{array}$ & Ahsan et al., 2008 \\
\hline & $\begin{array}{l}\text { IPG, 2-DE, } \\
\text { MALDI- } \\
\text { TOFMS, } \\
\text { ESI-MS/MS }\end{array}$ & Oryza sativa & $\begin{array}{l}12 \text { Proteins differentially expressed related with energy } \\
\text { production and metabolism. RuBisCO large subunit and } \\
\text { chloroplast } 29 \text { kDa ribonucleoproteins were decreased }\end{array}$ & $\begin{array}{l}\text { Reduction in photosynthetic } \\
\text { machinery proteins was related } \\
\text { with As toxicity }\end{array}$ & Ahsan et al., 2010 \\
\hline & $\begin{array}{l}\text { 2DE, MALDI- } \\
\text { TOF-MS, } \\
\text { LC-MS/MS }\end{array}$ & $\begin{array}{l}\text { Chlamydomonas } \\
\text { reinhardtii }\end{array}$ & $\begin{array}{l}15 \text { Proteins overexpressed like oxygen-evolving enhancer } \\
\text { protein, rubisco small subunit 1, chaperones, Fe-SOD, } \\
\text { Mn-SOD, and heat shock like proteins }\end{array}$ & $\begin{array}{l}\text { Organism exhibited time course } \\
\text { acclimation against As stress by } \\
\text { modulating protein signatures }\end{array}$ & $\begin{array}{l}\text { Walliwalagedara et al., } \\
2012\end{array}$ \\
\hline \multirow[t]{3}{*}{$\mathrm{Hg}$} & $\begin{array}{l}\text { 2-DE, } \\
\text { MALDI-TOF- } \\
\text { TOF-MS }\end{array}$ & Suaeda salsa & $\begin{array}{l}43 \text { Proteins with significant changes reported. They include } \\
\text { proteins related to metabolic processes, photosynthesis, } \\
\text { stress response, protein fate, energy metabolism, signaling } \\
\text { pathways, and immunosuppression }\end{array}$ & $\begin{array}{l}\text { Alterations in these proteins } \\
\text { was linked with } \mathrm{Hg} \text { toxicity }\end{array}$ & Liu et al., 2013 \\
\hline & $\begin{array}{l}\text { 2DE, } \\
\text { ESI-MS/MS }\end{array}$ & Oryza sativa & $\begin{array}{l}25 \text { Proteins differentially expressed by } \mathrm{Hg} \text { involved in } \\
\text { cellular functions including the redox and hormone } \\
\text { homeostasis, chaperone activity, metabolism, and } \\
\text { transcription regulation }\end{array}$ & $\begin{array}{l}\text { Plant exhibited } \mathrm{Hg} \text { toxicity due } \\
\text { to alterations in these proteins }\end{array}$ & Chen et al., 2012a \\
\hline & 2DE & Oryza sativa & $\begin{array}{l}33 \text { Proteins were highly reproducible. Most of the proteins } \\
\text { showed homology to RuBisCO protein, and some to } \\
\text { defense/stress-related proteins, like the pathogenesis } \\
\text { related class } 5 \text { protein (OsPR5), the probenazole-inducible } \\
\text { protein (referred to as the OsPR10), SOD, and the oxygen } \\
\text { evolving protein }\end{array}$ & $\begin{array}{l}\text { Severe fragmentation of } \\
\text { ribulose-1,5-bisphosphate } \\
\text { carboxylase/oxygenase and } \\
\text { induction of stress-related } \\
\text { proteins causes Hg toxicity }\end{array}$ & Hajduch et al., 2001 \\
\hline
\end{tabular}




\section{TABLE 3 | Continued}

\begin{tabular}{|c|c|c|c|}
\hline Metal & $\begin{array}{l}\text { Technique(s) } \\
\text { used }\end{array}$ & $\begin{array}{l}\text { Plant } \\
\text { species }\end{array}$ & Alterations in protein(s) expression profile \\
\hline \multirow[t]{2}{*}{$\mathrm{Cr}$} & $\begin{array}{l}\text { 2DE, } \\
\text { MALDI-TOF, } \\
\text { MALDI-TOF- } \\
\text { TOF }\end{array}$ & $\begin{array}{l}\text { Miscanthus } \\
\text { sinensis }\end{array}$ & $\begin{array}{l}36 \text { Proteins differentially expressed. The identified proteins } \\
\text { included: heavy metal-inducible proteins such as } \\
\text { carbohydrate and nitrogen metabolism, molecular } \\
\text { chaperone proteins, and novel proteins such as inositol } \\
\text { monophosphatase, nitrate reductase, adenine } \\
\text { phosphoribosyl transferase, formate dehydrogenase, and } \\
\text { a putative dihydrolipoamide dehydrogenase }\end{array}$ \\
\hline & $\begin{array}{l}\text { 2DE, MALDI- } \\
\text { TOF-MS-MS }\end{array}$ & Zea mays & $\begin{array}{l}58 \text { Proteins identified related with photosynthesis and } \\
\text { chloroplast organization, the redox homeostasis and } \\
\text { defense response, RNA processing, protein synthesis and } \\
\text { folding, DNA damage response, mitochondrial oxidative } \\
\text { phosphorylation, and miscellaneous with unknown function }\end{array}$ \\
\hline
\end{tabular}

\begin{tabular}{|c|c|c|c|}
\hline \multirow[t]{3}{*}{$\mathrm{Cu}$} & 2DE & Oryza sativa & $\begin{array}{l}\text { Changes RuBisCO, defense/stress-related proteins, like } \\
\text { the pathogenesis related class } 5 \text { protein (OsPR5), the } \\
\text { probenazole-inducible protein (referred to as the OsPR10 } \\
\text { and SOD }\end{array}$ \\
\hline & $\begin{array}{l}\text { SDS-PAGE } \\
\text { and 2DE }\end{array}$ & Oryza sativa & $\begin{array}{l}13 \text { Proteins identified such as metallothionein-like proteir } \\
\text { membrane-associated protein-like protein, putative } \\
\text { wall-associated protein kinase, pathogenesis-related } \\
\text { proteins, and the putative small GTP-binding protein Rak } \\
\text { which were up regulated by Cu stress. Three proteins, a } \\
\text { putative small cytochrome P450 (CYP90D2), a putative } \\
\text { thioredoxin and a putative GTPase, were down regulatec } \\
\text { by Cu stress }\end{array}$ \\
\hline & 2DE-MS & Populus sp. & $\begin{array}{l}450 \text { Proteins were reproducibly separated, including } \\
\text { metabolic processes proteins such as photosynthesis, S } \\
\text { assimilation, sugar metabolism, chaperones, and defens } \\
\text { related proteins such as GST, DHAR, APX }\end{array}$ \\
\hline & $\begin{array}{l}\text { IPG, 2-DE, } \\
\text { MALDI-TOF- } \\
\text { MS }\end{array}$ & $\begin{array}{l}\text { Ectocarpus } \\
\text { siliculosus }\end{array}$ & $\begin{array}{l}\text { Up-regulation of photosynthesis (PSII Mn-stabilizing } \\
\text { protein of OEC33), glycolysis, and pentose phosphate } \\
\text { metabolism; higher accumulation of HSP70 and vBPO }\end{array}$ \\
\hline & $\begin{array}{l}\text { IPG, 2-DE, } \\
\text { LC-MS/MS }\end{array}$ & $\begin{array}{l}\text { Cannabis } \\
\text { sativa }\end{array}$ & $\begin{array}{l}\text { Induced aldo/keto reductase, PCs expression, } \\
\text { suppression/no change in ROS scavenging enzymes }\end{array}$ \\
\hline
\end{tabular}

SDS-PAGE Oryza sativa
Plant response

Miscanthus plant experienced

Cr toxicity due to altered

vacuole $\mathrm{Cr}$ sequestration, nitrogen metabolism, and lipid peroxidation in roots

Plant exhibited Cr toxicity due to the deep changes in proteomics
References

Sharmin et al., 2012

Wang et al., 2013

Alterations in these protein

Hajduch et al., 2001 resulting in Cu stress

Plant experienced Cu toxicity due to a decline in thioredoxin and CYP90D2 and thus engineering of this protein may enhance $\mathrm{Cu}$ tolerance

Plant adjusts its metabolism against $\mathrm{Cu}$ stress by changing protein expression. These proteomic temporal features should be taken into account for the future development of metal tolerant plants

Cu stress leads to up-regulation of certain proteins such as HSP70 and vBPO for proper protein folding and ROS detoxification, respectively

$\mathrm{Cu}$ induced aldo/keto reductase acts as a Cu chaperone reduce $\mathrm{Cu}$ ions to $\mathrm{Cu}(\mathrm{l})$, promote PCs-mediated vacuolar transport in order to reduce $\mathrm{Cu}$ toxicity

Plant showed physiological alterations under Cu stress due to the change in metabolic pathway related proteins
Zhang et al., 2009a,b

Lingua et al., 2012

Ritter et al., 2010

Bona et al., 2007

Ahsan et al., 2007 and 2DE

samples. Among them, 18 protein spots were up-regulated, and 7 protein spots were down-regulated. Antioxidants proteins such as glyoxalase I, peroxiredoxin, aldose reductase, and DnaK-type molecular chaperone up-regulated. Moreover, down-regulation of key metabolic enzymes like alpha-amylase or enolase revealed also observed

521 Proteins identified. Among them, several were membrane proteins. IRT1, an iron and zinc transporter, and $\mathrm{FRO} 2$, a ferric-chelate reductase, increased greatly in response to excess $\mathrm{Zn}$

2DE-MS Populus sp.
450 Proteins were reproducibly separated, including metabolic processes proteins such as photosynthesis, $S$ assimilation, sugar metabolism, chaperones, and defense related proteins such as GST, DHAR, APX
Plant exhibits Zn stress in which V-ATPase activity might play a central role

Plant adjusts its metabolism against $\mathrm{Zn}$ stress by changing protein expression
Fukao et al., 2011

Lingua et al., 2012

(Continued) 


\section{TABLE 3 | Continued}

\begin{tabular}{|c|c|c|c|c|c|}
\hline Metal & $\begin{array}{l}\text { Technique(s) } \\
\text { used }\end{array}$ & $\begin{array}{l}\text { Plant } \\
\text { species }\end{array}$ & Alterations in protein(s) expression profile & Plant response & References \\
\hline \multirow[t]{2}{*}{$\mathrm{Ni}$} & $\begin{array}{l}\text { 2DE, MALDI- } \\
\text { TOF-MS }\end{array}$ & $\begin{array}{l}\text { Brassica } \\
\text { juncea }\end{array}$ & $\begin{array}{l}61 \text { Proteins differentially expressed. The majority of } \\
\text { proteins were found to be involved in S metabolism and } \\
\text { protection against oxidative stress. The induced } \\
\text { expression of photosynthesis and ATP generation-related } \\
\text { proteins were also observed }\end{array}$ & $\begin{array}{l}\text { An increased expression of } \\
\text { defense proteins and those } \\
\text { related with energy metabolism } \\
\text { suggesting the Ni tolerance in } \\
\text { plant is an energy-demanding } \\
\text { process }\end{array}$ & Wang et al., 2012 \\
\hline & $\begin{array}{l}\text { 2-DE, } \\
\text { LC-MS/MS }\end{array}$ & $\begin{array}{l}\text { Alyssum } \\
\text { lesbiacum }\end{array}$ & $\begin{array}{l}12 \text { Proteins differentially expressed. They include proteins } \\
\text { of S metabolism, antioxidants, heat shock }\end{array}$ & $\begin{array}{l}\text { Modulation in S metabolic and } \\
\text { defense related proteins } \\
\text { enhanced Ni tolerance of plant }\end{array}$ & Ingle et al., 2005 \\
\hline \multirow[t]{2}{*}{$\mathrm{Mn}$} & $\begin{array}{l}\text { IPG, 2-DE, } \\
\text { Nano-LC- } \\
\text { MS/MS, ESI } \\
\text { MS/MS }\end{array}$ & $\begin{array}{l}\text { Vigna } \\
\text { unguiculata }\end{array}$ & $\begin{array}{l}8 \text { Differentially expressed proteins indentified involved in } \\
\mathrm{CO}_{2} \text { fixation, stabilization of the Mn cluster of the } \\
\text { photosystem II, pathogenesis-response reactions, and } \\
\text { protein degradation }\end{array}$ & $\begin{array}{l}\text { Coordinated interplay of } \\
\text { apoplastic and symplastic } \\
\text { reactions help plant to } \\
\text { withstand Mn toxicity }\end{array}$ & Führs et al., 2008 \\
\hline & $\begin{array}{l}\text { 2DIEF/SDS- } \\
\text { PAGE, 2D } \\
\text { Blue native } \\
\text { BN/SDS- } \\
\text { PAGE }\end{array}$ & $\begin{array}{l}\text { Hordeum } \\
\text { vulgare }\end{array}$ & $\begin{array}{l}\text { A range of proteins differentially expressed in response to } \\
\text { Mn. A putative inorganic pyrophosphatase, a } \\
\text { probenazole-inducible protein (PBZ1), a protein belonging } \\
\text { to a universal stress protein (Usp) family, a chloroplast } \\
\text { translational elongation factor (Tu) and the } 50 \text { S ribosomal } \\
\text { protein } L 11\end{array}$ & $\begin{array}{l}\text { In young leaves toxicity resulted } \\
\text { due to } \mathrm{Mn} \text {-induced } \mathrm{Mg} \text { and Fe } \\
\text { deficiencies }\end{array}$ & Führs et al., 2010 \\
\hline
\end{tabular}

enhancing stress tolerance in a variety of crop species (Vriet et al., 2012). Although SA and GAs both are cost effective and can easily be availed for their exogenous application in crop fields under stress conditions, high cost of synthetic BRs and the variability of the results have discouraged the use of exogenous BRs in agriculture and horticulture (Khripach et al., 2000; Gomes, 2011). In this context, modulation of endogenous BRs levels by genetic engineering has emerged an efficient strategy for enhancing crop yield under normal as well as adverse growth conditions (Divi and Krishna, 2009). Herein, we have summarized recent advances made in enhancing heavy metal tolerance as well as achieving high yield with desired agronomic traits by using salicylic acid (SA), brassinosteroids (BRs), and gibberellins (GA).

\section{Salicylic Acid (SA)}

In recent years, SA has gained much scientific attention due to its function as an endogenous signaling molecule conveying local and systemic plant-pathogen defense responses. Besides this, it has been reported that SA also plays a role in plant response against abiotic stresses such as heavy metal toxicities, chilling, drought, osmotic stress, and heat. In this sense, SA appears to be an "effective therapeutic agent" for plants as in the case of mammals (Rivas-San Vicente and Plasencia, 2011). Salicylic acid is a phenolic compound biosynthesized in all the plant kingdoms through the phenylpropanoid pathway (Métraux, 2002).

Being well characterized and studied role of SA in pathogen resistance, an exogenous application of SA could also provide protection against several types of abiotic stresses such as heavy metals, high or low temperature, salinity, radiation, etc. (Horváth et al., 2007; Hayat et al., 2010). Since under stress condition, reduced plant growth could result from an altered hormonal status, and thus, an exogenous application of plant hormones like SA has been an attractive approach to attenuate heavy metal stress. Studies carried out so far demonstrated that SA treatment to plants evoke acclimatization effect, which causes an enhanced tolerance toward heavy metal stress primarily due to the adjustment of metabolic processes such as enhanced antioxidative capacity. In one of the first works, it was demonstrated that SA may induce protective effects against $\mathrm{Cu}$ toxicity in tobacco and cucumber (Strobel and Kuc, 1995). Later, an increasing numbers of studies have demonstrated SAmediated amelioration of toxicities produced by various heavy metals. Zhou et al. (2009) reported that $0.2 \mathrm{mM}$ of SA ameliorates $\mathrm{Hg}$ toxicity in alfalfa by increasing activity of APX, POD, and NADPH oxidase, and amounts of ascorbate, glutathione, and proline, and decreased lipid peroxidation, and an increase in NADPH oxidase activity. It indicates a role of ROS signaling in such an amelioration process.

In maize plant, $\mathrm{Cd}$ declined the growth by inhibiting chlorophyll synthesis, ribulose 1,5-bisphosphate carboxylase and phosphoenolpyruvate carboxylase, and enhancing oxidative damage such as lipid peroxidation and electrolyte leakage, whereas SA pretreatment of seeds reversed these toxic effects (Krantev et al., 2008). In cucumber, an exogenous application of SA has also been reported to enhance $\mathrm{Mn}$ tolerance by modulating nutrients' statuses and antioxidant defense system (Shi and Zhu, 2008). Similarly, in pea seedlings, Cd toxicity caused decline in growth due to an inhabited photosynthetic process and enhanced oxidative damage, whereas SA pretreatment alleviated damaging consequences of $\mathrm{Cd}$ on growth and photosynthesis (Popova et al., 2009). Moreover, Guo et al. (2009) have demonstrated that SA pretreatment alleviated $\mathrm{Cd}$ toxicity in rice by enhancing antioxidant components such as SOD, CAT, POD, glutathione, and non-protein thiols, which in turn depressed oxidative damage induced by Cd. Conversely, Metwally et al. (2003) reported that SA down-regulates activities 
of antioxidant enzymes such as CAT and APX under Cd stress and concluded that SA alleviates Cd toxicity not at the level of antioxidant defense system but by affecting other mechanisms of $\mathrm{Cd}$ detoxification. Contrary to this, SA at higher concentration may also cause tissue damage and cell death by inducing oxidative stress (Horváth et al., 2007). For instance, SA has been shown to potentiate generation of ROS in photosynthetic tissue under abiotic stresses and thus causes tissue damage (Borsani et al., 2001). Therefore, it can be concluded that the concentration of SA appears to be important in regulating stress responses. The SA-mediated alterations in genes that are involved in mediating stress tolerance are listed in Table 4.
It is known that SA also involves in the regulation of oxidative stress caused by various stress factors (Yang et al., 2004). An enhanced level of SA under heavy metal stress suggests a connection between the extent of plant tolerance to heavy metal, which is mediated by the SA signal and the redox balance (Metwally et al., 2003; Sharma and Dietz, 2009). In the SA signaling under heavy metal stress, several signaling molecules such as nitric oxide (NO), $\mathrm{H}_{2} \mathrm{O}_{2}, \mathrm{Ca}^{+2}$, etc. and their interactions have been reported (Rodríguez-Serrano et al., 2009; Xu et al., 2014). Moreover, Cui et al. (2012b) have reported a cross-talk of haem oxygenase-1 and SA in alleviation of Cd stress in $M$. sativa. In spite of considerable progress in the understanding of

TABLE 4 | Summary of plant hormone-mediated alterations in genes and their relation with an increased heavy metal stress tolerance.

\begin{tabular}{|c|c|c|c|c|}
\hline Plant hormone & Alteration in gene(s) & Studied plant & Response & References \\
\hline \multirow[t]{4}{*}{ Salicylic acid } & Heam oxygenase-1 (HO-1) & Medicago sativa & $\begin{array}{l}\text { Alleviation of } \mathrm{Cd} \text {-triggered oxidative stress by } \\
\text { re-establishing redox homeostasis }\end{array}$ & Cui et al., 2012b \\
\hline & Citrate synthase & Cassia tora & Enhanced Al tolerance through an efflux of citrate & Yang et al., 2003 \\
\hline & SR3 & Phaseolus vulgaris & $\begin{array}{l}\text { This gene up-regulated by } \mathrm{SA} \text { and provides resistance } \\
\text { against } \mathrm{Hg}, \mathrm{Cd}, \mathrm{As} \text {, and } \mathrm{Cu}\end{array}$ & Zhang et al., 2006 \\
\hline & MT1 and MT2 & Arabidopsis thaliana & $\begin{array}{l}\text { SA did not alter expression of these genes hence did not } \\
\text { impart Cu tolerance }\end{array}$ & Murphy and Taiz, 1995 \\
\hline
\end{tabular}

Brassinosteroids Antioxidant defense related Raphanus sativus genes

Fe-SOD, CAT1, APX, GST1, GR, POD, GSH1, PAL, PPO, $S K D H$, and $C A D$

Genes encoding polyamines, IAA and ABA metabolic genes, and $\mathrm{Cu}$ homeostasis

HSP83, HAT2, GH3.9, SAL2, NIA1, GAS4, SAUR36, DWARF1, DWARF4, and BR6OX

$\mathrm{NADPH}$ oxidase and $\mathrm{RBOH}$, $M A P K 1$, and MAPK3

Induced NO production that up-regulates ABA biosynthetic gene vp14

Set of stress marker genes

UBC32, a stress-induced functional ubiquitin conjugation enzyme (E2)

Gibberellic acid IRT1

CAX2

GA-biosynthesis and redox genes

adenosine $5^{\prime}$-phosphosulfate reductase (APR)

Cucumis sativus

Zea mays

Brassica napus

Glycine max
Solanum lycopersicum

Increased resistance against $\mathrm{Cr}$ toxicity due to diminished production of ROS and an enhanced defense system

Alleviates Cd-induced inhibition on photosynthesis by up-regulating defense system and decreasing oxidative stress

Raphanus sativus Lower ion leakage due to a maintenance of $\mathrm{Cu}$ homeostasis and hence an enhanced Cu tolerance

Arabidopsis thaliana

BR-exhibited synergistic effect with Cd and increased Cd sensitivity of plants

Arabidopsis thaliana

\section{BR-mediated production of $\mathrm{H}_{2} \mathrm{O}_{2}$ via $\mathrm{NADPH}$ oxidase} increased stress tolerance in cooperation with kinases BR-induced NO production that up-regulates ABA biosynthesis gene vp14 and thus confers stress tolerance

Increased tolerance against abiotic stresses such as drought and cold

Protects plants from abiotic stress through endoplasmic reticulum (ER)-associated protein degradation (ERAD) component and UBC32 plays a crucial role in such protection

GA-suppressed up-regulation of IRT1 and enhanced accumulation of $\mathrm{NO}$ that enhanced $\mathrm{Cd}$ tolerance

Arabidopsis thaliana GAdid Nicotiana tabacum

Arabidopsis thaliana
GA did not influence expression of this gene and did not alter $\mathrm{Mn}$ and $\mathrm{Cd}$ tolerance

Increased Cu tolerance due to decreased oxidative damage and enhanced antioxidant defense system GA plays a role in abiotic stress tolerance via regulating $S$ assimilation pathway
Choudhary et al., 2012b

Ahammed et al., 2013

Choudhary et al., 2012a

Villiers et al., 2012

Xia et al., 2009

Zhang et al., 2011

Kagale et al., 2007

Cui et al., 2012a

Zhu et al., 2012

Hirschi et al., 2000

Khan and Lee, 2013

Koprivova et al., 2008

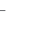


SA signaling, molecular events, which are involved in the SA signaling in order to alleviate heavy metal stress, are still poorly known (Figure 4).

\section{Brassinosteroids (BRs)}

Brassinosteroids are group of hormones having ability of regulating ion uptake in plant cells and very effectively reducing the heavy metal accumulation in plants. BRs can also impart plant stress tolerance against variety of biotic and abiotic stresses such as heavy metal, salinity, drought, low and high temperatures, and pathogen attack (Bajguz and Hayat, 2009; Hao et al., 2013). An increasing numbers of studies have shown that an exogenous application of BRs is widely used in order to improve crop yield as well as stress tolerance in various plant species (Divi and Krishna, 2009; Peleg and Blumwald, 2011; Li et al., 2013). Cadmium, a heavy metal, very toxic even when present in trace amount, have been found to retard chlorophyll biosynthesis, activity of several enzymes, and inhibit light and dark reactions of photosynthesis by limiting the energy/reducing sources (Vassilev and Yordanov, 1997). However, it has been reported that $\mathrm{Cd}$-induced toxicity can be lowered with $\mathrm{BR}$. For instance, Janeckzo et al. (2005) reported that Cd-induced inhibition in pigments content, cotyledon growth could be minimized with exogenous epibrassinolide (EPL: another BR). Hayat et al. (2007) have verified the role of HBL under Cd stress in B. juncea. In Vigna radiata L. Wilczek, Al stress caused a reduction in length, fresh and dry mass of root and shoot; activity of carbonic anhydrase; water use efficiency; relative water content; chlorophyll content; and the rate of photosynthesis, whereas addition of BR reversed these toxic effects and protected the plants via elevated level of proline in an association with an antioxidant defense system which at least in part was responsible for the amelioration of $\mathrm{Al}$ stress (Ali et al., 2008). In B. juncea, BR alleviates Cd toxicity through enhanced level of antioxidants (Hayat et al., 2007). The Cr, a known toxic metal, reduced the growth performance of Raphanus sativus L., whereas BR protects plants from adverse consequences of $\mathrm{Cr}$ toxicity by regulating antioxidant defense system (Sharma et al., 2011).

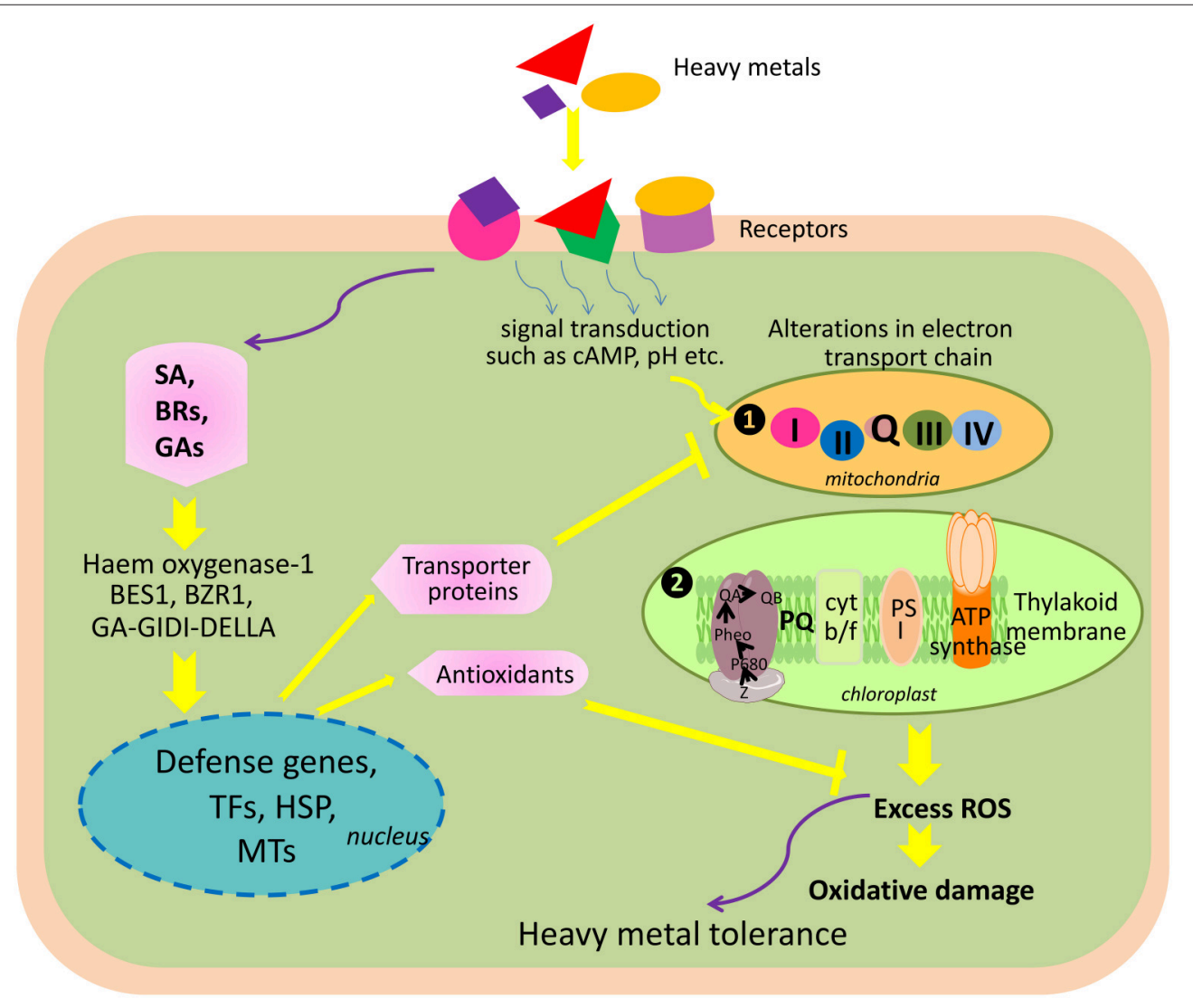

FIGURE 4 | Schematic representation of plant hormone-mediated alleviation of heavy metal toxicity in plants. Heavy metals' signals are perceived by receptors, and receptors transduce signals via cAMP, $\mathrm{pH}$, etc. causing alterations in electron transport systems of the cell, which results into an excess production of reactive oxygen species (ROS). ROS cause damage to macromolecules and thus create oxidative stress inside the cell. On the other hand, in the presence of plant hormones, signals received by them initiate a cascade of signal transduction involving haem oxygenase, two transcription factors induced by brassinosteroids (BES1 and BZR1) and a gibberellic acid-mediated GA-GID1-DELLA signaling pathway. These factors, in turn, initiate expression of the nuclear genes encoding defense proteins, transcription factors (TFs), heat shock proteins (HSP), and metal transporter proteins (MTs). MTs protect electron transport chains against heavy metals by regulating their uptake. Defense proteins protect plant against ROS under heavy metal stress (Numbers 1 and 2 designated to chloroplast and mitochondria show the sources of ROS in cell). 
Micronutrients such as $\mathrm{Cu}$ and $\mathrm{Ni}$ are essential for growth and development, but in excess, they cause severe toxic effects. $\mathrm{Cu}$, which has increasingly attained interest due to its use in fungicides, fertilizers, and pesticides, is also highly toxic to plants, but when seeds of $B$. juncea primed with epibrassinolide (a form of BR) were exposed to $\mathrm{Cu}$ stress, improvement in shoot emergence and biomass accumulation, along with reduced $\mathrm{Cu}$ uptake and accumulation, was noticed (Sharma and Bhardwaj, 2007). Similar protective responses of exogenous BR on B. juncea and $V$. radiata under $\mathrm{Cu}$ and $\mathrm{Ni}$ toxicities have been reported (Alam et al., 2007; Sharma et al., 2008; Fariduddin et al., 2009; Yusuf et al., 2012b). Besides higher plants, BR has also been found to be effective in alleviating heavy metals such as $\mathrm{Cu}$, $\mathrm{Pb}$, and $\mathrm{Cd}$ toxicities in algae, Chlorella vulgaris, through the regulation of antioxidant defense system (Bajguz, 2010). The BRmediated alterations in the gene expressions and their roles in stress tolerance are listed in Table 2.

\section{Gibberellic Acid (GA)}

The gibberellins (GAs) are a large family of tetracyclic diterpenoid plant growth hormone associated with the plant growth and developmental processes (Matsuoka, 2003). To alleviate deleterious effects of stress, different types of plant hormones have been used that might complement decreased and/or imbalanced hormone level during exposure of stress. Of these, GA has been a focus of plant scientists (Hisamatsu et al., 2000; Iqbal et al., 2011; Zhu et al., 2012).

Several studies revealed that GA alleviates various abiotic stresses including heavy metal toxicity. In A. thaliana, GA ( $5 \mu \mathrm{M})$ is reported to ameliorate $\mathrm{Cd}$ toxicity by reducing $\mathrm{Cd}$ uptake and lipid peroxidation (Zhu et al., 2012). Furthermore, authors demonstrated that GA reduces NO level which in turn downregulates expression of IRT1 gene, a Fe transporter (might be involved in Cd absorption) as indicated by no effect of GA in reduction of Cd uptake in an IRT1 knockout mutant irt1. It is reported that an exogenous addition of GA reprograms the growth of soybean under stress conditions by enhancing the levels of daidzein and genistein contents, suggesting protective role of GA in mitigating adverse consequences of stressors (Hamayun et al., 2010). In wheat seedlings, $\mathrm{Ni}(50 \mathrm{mM})$ has been shown to decline growth, chlorophyll content, and carbonic anhydrase activity by enhancing oxidative stress, whereas an addition of GA ameliorates Ni-induced toxic effects (Siddiqui et al., 2011). Gangwar et al. (2011) have also reported that an exogenous addition of GA ameliorates toxic effects of $\mathrm{Cr}$ $(50-250 \mu \mathrm{M})$ on growth and ammonium assimilation of pea seedlings by regulating oxidative stress and an antioxidant system. In B. napus L., GA $(50 \mu \mathrm{M})$ has been shown to alleviate Cd (10-400 $\mu \mathrm{M})$-induced negative impact on seed germination and growth by regulating oxidative stress and damage (Meng et al., 2009). It has been observed that $\mathrm{Pb}$ and $\mathrm{Zn}$ affect seed germination in Cicer arietinum cv. Aziziye-94 by altering hormonal balance, and an exogenous application of GA reverses the toxic effect of heavy metals (Atici et al., 2005). Furthermore, Sharaf et al. (2009) have also reported that GA mitigates detrimental effects of $\mathrm{Cd}$ and $\mathrm{Pb}$ on broad bean and lupin plants by regulating activities of proteases, CAT, and POD. These studies clearly indicate that GA plays an important role in protecting plant metabolism against various stresses; however, this may occur via various routes suggesting complex GA signaling during plant acclimation against stresses. The GA-mediated alterations in genes and their relation with stress tolerance are summarized in Table 4.

\section{CONCLUSION AND FUTURE PROSPECTS}

Around 3.1 billion people from developing countries live in rural areas, and out of this population, $\sim 2.5$ billion people depend on agricultural practices for their livelihood, which contributes $30 \%$ to economic growth because of the gross domestic products obtained from agriculture (FAO, 2012). It is expected that world population will be about 10 billion by the middle of the twenty-first century, and we will witness serious food shortages (Smith et al., 2010; Naika et al., 2013). Furthermore, the situation will likely to be severe due to increased anthropogenic activities that have resulted into unwanted changes in the environment such as soil, air, and water pollution with various factors including heavy metal. These situations (pollution and population) are posing a continuously increasing burden on global crop productivity, and hence, there are demands for crop varieties that should be adaptive and resistant to various stresses.

In contrast to biotic stress, which is under the control of monogenic trait, abiotic stress tolerance is a genetically complex process that involves many components of signaling pathways, multigenic in nature, and thus, comparatively more difficult to control and engineer (Vinocur and Altman, 2005). Therefore, plant-engineering strategies for heavy metal tolerance depend on the expression of gene(s) whose product(s) are involved either in signaling and regulatory pathways or in the synthesis of functional and structural proteins and metabolites that confer heavy metal stress tolerance. Recently, several efforts are being made to improve heavy metal stress tolerance capacity through genetic engineering with several achievements; however, the genetically complex mechanisms of heavy metal stress tolerance and transfer of technology to field conditions make it difficult. Advances in various functional tools, resources, and "omics" have helped in the molecular characterization of the genes, metabolites, and proteins involved in heavy metal stress tolerance. Furthermore, genetic engineering of heavy metal-responsive genes (particularly TFs), metabolites, and proteins has shown surprising results but its full potential remains to be exploited. The design of future experiments that use a multidisciplinary approach with well-integrated "omics," i.e., transcritomics, metabolomics, proteomics, etc. ultimately required to significantly improve heavy metal tolerance as well as tolerance to other abiotic stresses in economically important crop plants.

\section{ACKNOWLEDGMENTS}

The University Grants Commission, Central Regional Office, Bhopal and New Delhi are greatly acknowledged for providing 
financial support to Dr. VS (PI-UGC Minor research Project, File No. MS-27/201022/XII/13-14/CRO) and Dr. SP (PI- UGC Major research Project no: 41-460/2012(SR)) respectively. We are also very grateful to Department of Botany, University

\section{REFERENCES}

Abul Kashem, M. D. A., and Kawai, S. (2007). Alleviation of cadmium phytotoxicity by magnesium in Japanese mustard spinach. Soil Sci. Plant Nutr. 53, 246-251. doi: 10.1111/j.1747-0765.2007.00129.x

Acquaah, G. (2007). Principles of Plant Genetics and Breeding. Oxford, UK: Blackwell.

Ahammed, G. J., Choudhary, S. P., Chen, S., Xia, X., Shi, K., Zhou, Y., et al. (2013). Role of brassinosteroids in alleviation of phenanthrene-cadmium co-contamination-induced photosynthetic inhibition and oxidative stress in tomato. J. Exp. Bot. 64, 199-213. doi: 10.1093/jxb/ers323

Ahsan, N., Lee, D. G., Alam, I., Kim, P. J., Lee, J. J., Ahn, Y. O., et al. (2008). Comparative proteomic study of arsenic-induced differentially expressed proteins in rice roots reveals glutathione plays a central role during As stress. Proteomics 8, 3561-3576. doi: 10.1002/pmic.200701189

Ahsan, N., Lee, D. G., Kim, K. H., Alam, I., Lee, S. H., Lee, K. W., et al. (2010). Analysis of arsenic stress-induced differentially expressed proteins in rice leaves by two-dimensional gel electrophoresis coupled with mass spectrometry. Chemosphere 78, 224-231. doi: 10.1016/j.chemosphere.2009.11.004

Ahsan, N., Lee, D. G., Lee, S. H., Kang, K. Y., Lee, J. J., Kim, P. J., et al. (2007). Excess copper induced physiological and proteomic changes in germinating rice seeds. Chemosphere 67, 1182-1193. doi: 10.1016/j.chemosphere.2006.10.075

Ahsan, N., Renaut, J., and Komatsu, S. (2009). Recent developments in the application of proteomics to the analysis of plant responses to heavy metal. Proteomics 9, 2602-2621. doi: 10.1002/pmic.200800935

Alam, M. M., Hayat, S., Ali, B., and Ahmad, A. (2007). Effect of 28homobrassinolide treatment on nickel toxicity in Brassica juncea. Photosynthetica 45, 139-142. doi: 10.1007/s11099-007-0022-4

Ali, B., Hasan, S. A., Hayat, S., Hayat, Q., Yadav, S., Fariduddin, Q., et al. (2008). A role for brassinosteroids in the amelioration of aluminium stress through antioxidant system in mung bean (Vigna radiata L. Wilczek). Environ. Exp. Bot. 62, 153-159. doi: 10.1016/j.envexpbot.2007.07.014

Ali, B., Qian, P., Jin, R., Ali, S., Khan, M., Aziz, R., et al. (2013a). Physiological and ultra-structural changes in Brassica napus seedlings induced by cadmium stress. Biol. Plant. 58, 131-138. doi: 10.1007/s10535-013-0358-5

Ali, B., Wang, B., Ali, S., Ghani, M. A., Hayat, M. T., Yang, C., et al. (2013b). 5-Aminolevulinic acid ameliorates the growth, photosynthetic gas exchange capacity, and ultrastructural changes under cadmium stress in Brassica napus L. J. Plant Growth Regul. 32, 604-614. doi: 10.1007/s00344-013-9328-6

Anderson, N. L., and Anderson, N. G. (1998). Proteome and proteomics: new technologies, new concepts, and new words. Electrophoresis 19, 1853-1861. doi: 10.1002/elps.1150191103

Anjum, N. A., Gill, S. S., Gill, R., Hasanuzzaman, M., Duarte, A. C., Pereira, E., et al. (2014). Metal/metalloid stress tolerance in plants: role of ascorbate, its redox couple, and associated enzymes. Protoplasma 251, 1265-1283. doi: 10.1007/s00709-014-0636-x

Anjum, N. A., Umar, S., Ahmad, A., Iqbal, M., and Khan, N. A. (2008). Sulphur protects Mustard (Brassica campestris L.) from cadmium toxicity by improving leaf ascorbate and glutathione. Plant Growth Regul. 54, 271-279. doi: 10.1007/s10725-007-9251-6

Apel, K., and Hirt, H. (2004). Reactive oxygen species: metabolism, oxidative stress, and signal transduction. Annu. Rev. Plant Biol. 55, 373-399. doi: 10.1146/annurev.arplant.55.031903.141701

Arbona, V., Manzi, M., Ollas, C. D., and Gonez-Cadenao, A. (2013). Metabolites as a tool to investigate abiotic stress tolerance in plants. Int. J. Mol. Sci. 14, 4885-4911. doi: 10.3390/ijms14034885

Arenhart, R. A., De Lima, J. C., Pedron, M., Carvalho, F. E. L., Da Silveira, J. A. G., Rosa, S. B., et al. (2013). Involvement of ASR genes in aluminium tolerance mechanisms in rice. Plant Cell Environ. 36, 52-67. doi: 10.1111/j.13653040.2012.02553.x of Allahabad for providing necessary lab facilities and also to University Grant Commission for providing financial support to $\mathrm{PP}$ and $\mathrm{RS}$ as research fellow to carry out this work.

Arrivault, S., Senger, T., and Krämer, U. (2006). The Arabidopsis metal tolerance protein AtMTP3 maintains metal homeostasis by mediating $\mathrm{Zn}$ exclusion from the shoot under Fe deficiency and Zn oversupply. Plant J. 46, 861-879. doi: 10.1111/j.1365-313X.2006.02746.x

Asada, K. (1992). Ascorbate peroxidase: a hydrogen peroxide scavenging enzyme in plants. Plant Physiol. 85, 235-241. doi: 10.1111/j.1399-3054.1992.tb04728.x

Asada, K. (1996). "Radical production and scavenging in chloroplasts," in Photosynthesis and the Environment, ed N. Baker (Dordrecht: Kluwer; Atlantic Canada Society for Microbial Ecology; Halifax), 123-150.

Assuncão, A. G. L., Schat, H., and Aarts, M. G. M. (2003). Thlaspi caerulescens, an attractive model species to study heavy metal hyperaccumulation in plants. New Phytol. 159, 351-360. doi: 10.1046/j.1469-8137.2003.00820.x

Assunção, A. G., Da Costa Martins, P., De Folter, S., Vooijs, R., Schat, H., and Aarts, M. G. M. (2001). Elevated expression of metal transporter genes in three accessions of the metal hyperaccumulator Thlaspi caerulescens. Plant Cell Environ. 24, 217-226. doi: 10.1111/j.1365-3040.2001.00666.x

Assunção, A. G., Herrero, E., Lin, Y. F., Huettel, B., Talukdar, S., Smaczniak, C., et al. (2010). Arabidopsis thaliana transcription factors bZIP19 and bZIP23 regulate the adaptation to zinc deficiency. Proc. Natl. Acad. Sci. U.S.A. 107, 10296-10301. doi: 10.1073/pnas.1004788107

Astolfi, S., Zuchi, S., and Passera, C. (2004). Role of sulphur availability on cadmium-induced changes of nitrogen and sulphur metabolism in maize (Zea mays L.) Leaves. J. Plant Physiol. 161, 795-802. doi: 10.1016/j.jplph.2003. 11.005

Atici, Ö., Ağar, G., and Battal, P. (2005). Changes in phytohormone contents in chickpea seeds germinating under lead or zinc stress. Biol. Plant. 49, 215-222. doi: 10.1007/s10535-005-5222-9

Atkinson, N. J., and Urwin, P. E. (2012). The interaction of plant biotic and abiotic stresses: from genes to the field. J. Exp. Bot. 63, 3523-3544. doi: $10.1093 / \mathrm{jxb} / \mathrm{ers} 100$

Axelsen, K. B., and Palmgren, M. G. (1998). Evolution of substrate specificities in the P-type ATPase superfamily. J. Mol. Evol. 46, 84-101. doi: 10.1007/PL00006286

Azzarello, E., Pandolfi, C., Giordano, C., Rossi, M., Mugnai, S., and Mancuso, S. (2012). Ultramorphological and physiological modifications induced by high zinc levels in Paulownia tomentosa. Environ. Exp. Bot. 81, 11-17. doi: 10.1016/j.envexpbot.2012.02.008

Babu, T. S., Akhtar, T. A., Lampi, M. A., Tripuranthakam, S., Dixon, D. G., and Greenberg, B. M. (2003). Similar stress responses are elicited by copper and ultraviolet radiation in the aquatic plant Lemnagibba: implication of reactive oxygen species as common signals. Plant Cell Phys. 44, 1320-1329. doi: $10.1093 / \mathrm{pcp} / \mathrm{pcg} 160$

Bajguz, A. (2010). An enhancing effect of exogenous brassinolide on the growth and antioxidant activity in Chlorella vulgaris cultures under heavy metal stress. Environ. Exp. Bot. 68, 175-179. doi: 10.1016/j.envexpbot.2009.11.003

Bajguz, A., and Hayat, S. (2009). Effects of brassinosteroids on the plant responses to environmental stresses. Plant Physiol. Biochem. 47, 1-8. doi: 10.1016/j.plaphy.2008.10.002

Barker, A. V., and Pilbeam, D. J. (2007). Hand Book of Plant Nutrition. Boca Raton, FL: Taylor and Francis.

Bashri, G., and Prasad, S. M. (2015). Indole acetic acid modulates changes in growth, chlorophyll a fluorescence and antioxidant potential of Trigonella foenum-graecum L. grown under cadmium stress. Acta Physiol. Plant. 37:1745. doi: 10.1007/s11738-014-1745-z

Basile, A., Sorbo, S., Pisani, T., Paoli, L., Munzi, S., and Loppi, S. (2012). Bioacumulation and ultrastructural effects of $\mathrm{Cd}, \mathrm{Cu}, \mathrm{Pb}$ and $\mathrm{Zn}$ in the moss Scorpiurum circinatum (Brid.) Fleisch \& Loeske. Environ. Pollut. 166, 208-211. doi: 10.1016/j.envpol.2012.03.018

Basu, U., Good, A. G., and Taylor, G. J. (2001). Transgenic Brassica napus plants overexpressing aluminium-induced mitochondrial manganese superoxide 
dismutase cDNA are resistant to aluminium. Plant Cell Environ. 24, 1278-1269. doi: 10.1046/j.0016-8025.2001.00783.x

Baszynski, T., Wajda, L., Krol, M., Wolinska, D., Krupa, Z., and Tukendorf, A. (1980). Photosynthetic activities of cadmium-treated tomato plants. Physiol. Plant. 48, 365-370. doi: 10.1111/j.1399-3054.1980.tb03269.x

Becher, M., Talke, I. N., Krall, L., and Krämer, U. (2004). Cross-species microarray transcript profiling reveals high constitutive expression of metal homeostasis genes in shoots of the zinc hyperaccumulator Arabidopsis halleri. Plant J. 37, 251-268. doi: 10.1046/j.1365-313X.2003.01959.x

Bellion, M., Courbot, M., Jacob, C., Guinet, F., Blaudez, D., and Chalot, M. (2007). Metal induction of a Paxillus involutus metallothionein and its heterologous expression in Hebeloma cylindrosporum. New Phytol. 174, 151-158. doi: 10.1111/j.1469-8137.2007.01973.x

Belokobylsky, A. I., Ginturi, E. I., Kuchava, N. E., Kirkesali, E. I., Mosulishvili, L. M., Frontasyeva, M. V., et al. (2004). Accumulation of selenium and chromium in the growth dynamics of Spirulina platensis. J. Radioanal. Nucl. Chem. 259, 65-68. doi: 10.1023/B:JRNC.0000015807.53132.c0

Belouchi, A., Kwan, T., and Gros, P. (1997). Cloning and characterization of the OsNramp family from Oryza sativa, a new family of membrane proteins possibly implicated in the transport of metal ions. Plant Mol. Biol. 33, 1085-1092. doi: 10.1023/A:1005723304911

Bernal, M. P., McGrath, S. P., Miller, A. J., and Baker, A. J. M. (1994). Comparison of the chemical changes in the rhizosphere of the nickel hyperaccumulator Alyssum murale with the non-accumulator Raphanus sativus. Plant Soil 64, 251-259. doi: 10.1007/BF00010077

Bharwana, S. A., Ali, S., Farooq, M. A., Iqbal, N., Abbas, F., and Ahmad, M. S. A. (2013). Alleviation of lead toxicity by silicon is related to elevated photosynthesis, antioxidant enzymes suppressed lead uptake and oxidative stress in cotton. J. Bioremed. Biodeg. 4, 4. doi: 10.4172/2155-6199. 1000187

Blanvillain, R., Wei, S., Wei, P., Kim, J. H., and Ow, D. W. (2011). Stress tolerance to stress escape in plants: role of the OXS2 zinc-finger transcription factor family. EMBO J. 30, 3812-3822. doi: 10.1038/emboj.2011.270

Blaudez, D., Kohler, A., Martin, F., Sanders, D., and Chalot, M. (2003). Poplar metal tolerance protein 1 (MTP1) confers zinc tolerance and is an oligomeric vacuolar zinc transporter with an essential leucine zipper motif. Plant Cell 15, 2911-2928. doi: 10.1105/tpc.017541

Bobrowicz, P., Wysocki, R., Owsianik, G., Goffeau, A., and Ulaszewski, S. (1997). Isolation of three contiguous genes, ACR1, ACR2 and ACR3, involved in resistance to arsenic compounds in the yeast Saccharomyces cerevisiae. Yeast $13,819-828$.

Bona, E., Marsano, F., Cavaletto, M., and Berta, G. (2007). Proteomic characterization of copper stress response in Cannabis sativa roots. Proteomics 7, 1121-1130. doi: 10.1002/pmic.200600712

Borsani, O., Valpuesta, V., and Botella, M. A. (2001). Evidence for a role of salicylic acid in the oxidativedamage generated by $\mathrm{NaCl}$ and osmotic stress in Arabidopsis seedlings. Plant Physiol. 126, 1024-1030. doi: 10.1104/pp.126.3.1024

Briat, J. F., Curie, C., and Gaymard, F. (2007). Iron utilization and metabolism in plants. Curr. Opin. Plant Biol. 10, 276-282. doi: 10.1016/j.pbi.2007.04.003

Buendía-González, L., Orozco-Villafuerte, J., Cruz-Sosa, F., Barrera-Díaz, C. E., and Vernon-Carter, E. J. (2010). Prosopis laevigata a potential chromium (VI) and cadmium (II) hyperaccumulator desert plant. Biores. Technol. 101, 5862-5867. doi: 10.1016/j.biortech.2010.03.027

Burló, F., Guijarro, I., Carbonell-Barrachina, A. A., Vlaero, D., and MartínezSánchez, F. (1999). Arsenic species: effects on and accumulation by tomato plants. J. Agric. Food Chem. 47, 1247-1253. doi: 10.1021/jf9806560

Caille, N., Zhao, F. J., and McGrath, S. P. (2005). Comparison of root absorption, translocation and tolerance of arsenic in the hyperaccumulator Pteris vittata and the nonhyperaccumulator Pteris tremula. New Phytol. 165, 755-761. doi: 10.1111/j.1469-8137.2004.01239.x

Cailliatte, R., Lapeyre, B., Briat, J. F., Mari, S., and Curie, C. (2009). The NRAMP6 metal transporter contributes to cadmium toxicity. Biochem. J. 422, 217-228. doi: 10.1042/BJ20090655

Cailliatte, R., Schikora, A., Briat, J. F., Mari, S., and Curie, C. (2010). Highaffinity manganese uptake by the metal transporter NRAMP1 is essential for Arabidopsis growth in low manganese conditions. Plant Cell 22, 904-917. doi: $10.1105 /$ tpc. 109.073023
Callahan, D. L., Baker, A. J. M., Kolev, S. D., and Wedd, A. G. (2006). Metal ion ligands in hyperaccumulating plants. J. Biol. Inorg. Chem. 11, 2-12. doi: 10.1007/s00775-005-0056-7

Carbonell, A. A., Aarabi, M. A., DeLaune, R. D., Gambrell, R. P., and Patrick, Jr., W. H. (1998). Arsenic in wetland vegetation: availability, phytotoxicity, uptake and effects on plant growth and nutrition. Sci. Total Environ. 217, 189-199. doi: 10.1016/S0048-9697(98)00195-8

Carbonell-Barrachina, A. A., Burló -Carbonell, F., and Mataix-Beneyto, J. (1997). Effect of sodium arsenite and sodium chloride on bean plant nutrition (macronutrients). J. Plant Nutr. 20, 1617-1633. doi: $10.1080 / 01904169709365361$

Carbonell-Barrachina, A., Burló -Carbonell, F., and Mataix-Beneyto, J. (1994). Effect of arsenite on the concentration of micronutrients in tomato plants grown in hydroponic culture. J. Plant Nutr. 17, 1887-1903. doi: $10.1080 / 01904169409364853$

Castrillo, G., Sánchez-Bermejo, E., de Lorenzo, L., Crevillén, P., Fraile-Escanciano, A., Tc, M., et al. (2013). WRKY6 Transcription factor restricts arsenate uptake and transposon activation in Arabidopsis. Plant Cell 25, 2944-2957. doi: 10.1105/tpc.113.114009

Cataldo, D. A., Garland, T. R., and Wildung, R. E. (1983). Cadmium uptake kinetics in intact soybean plants. Plant Physiol. 73, 844-848. doi: 10.1104/pp.73.3.844

Cataldo, D. A., McFadden, K. M., Garland, T. R., and Wildung, R. E. (1988). Organic constituents and complexation of nickel(II), iron(III), cadmium(II), and plutonium(IV) in soybean xylem exudates. Plant Physiol. 86, 734-739. doi: 10.1104/pp.86.3.734

Chaffei, C., Gouia, H., and Ghorbel, M. H. (2003). Nitrogen metabolism in tomato plants under cadmium stress. J. Plant Nutr. 26, 1617-1634. doi: 10.1081/PLN120022372

Chao, D. Y., Chen, Y., Chen, J., Shi, S., Chen, Z., Wang, C., et al. (2014). Genome-wide association mapping identifies a new arsenate reductase enzyme critical for limiting arsenic accumulation in plants. PLoS Biol. 12:e1002009. doi: 10.1371/journal.pbio.1002009

Chao, D.-Y., Silva, A., Baxter, I., Huang, Y. S., Nordborg, M., Danku, J., et al. (2012). Genome-wide association studies identify heavy metal ATPase3 as the primary determinant of natural variation in leaf cadmium in Arabidopsis thaliana. PLoS Biol. 8:e1002923. doi: 10.1371/journal.pgen.1002923

Chaurasia, N., Mishra, Y., and Rai, L. C. (2008). Cloning expression and analysis of phytochelatin synthase (pcs) gene from Anabaena sp. PCC 7120 offering multiple stress tolerance in Escherichia coli. Biochem. Biophys. Res. Commun. 376, 225-230. doi: 10.1016/j.bbrc.2008.08.129

Chen, J., Zhou, J., and Goldsbrough, P. B. (1997). Characterization of phytochelatin synthase from tomato. Physiol. Plant. 101, 165-172. doi: 10.1111/j.13993054.1997.tb01833.x

Chen, Y. A., Chi, W. C., Huang, T. L., Lin, C. Y., Quynh Nguyeh, T. T., Hsuing, Y. C., et al. (2012a). Mercury-induced biochemical and proteomic changes in rice roots. Plant Physiol. Biochem. 55, 23-32. doi: 10.1016/j.plaphy.2012. 03.008

Chen, Z., Pan, Y., Wang, S., Ding, Y., Yang, W., and Zhu, C. (2012b). Overexpression of a protein disulfide isomerase-like protein from Methanothermobacter thermoautotrophicum enhances mercury tolerance in transgenic rice. Plant Sci. 197, 10-20. doi: 10.1016/j.plantsci.2012.08.005

Chiang, C. M., Chen, S. P., Chen, L. F. O., Chiang, M. C., Chien, H. L., and Lin, K. H. (2013). Expression of the broccoli catalase gene (BoCAT) enhances heat tolerance in transgenic Arabidopsis. J. Plant Biochem. Biotechnol. 23, 266-277. doi: 10.1007/s13562-013-0210-1

Cho, S. H., Hoang, Q., Phee, J. W., Kim, Y. Y., Shin, H. Y., and Shin, J. S. (2007). Modified suppression subtractive hybridization identifies an AP2-containing protein involved in metal responses in Physcomitrella patens. Mol. Cells 23, 100-107.

Chong-qing, W., Tao, W., Ping, M., Zi-chao, L., and Ling, Y. (2013). Quantitative trait loci for mercury tolerance in rice seedlings. Rice Sci. 20, 238-242. doi: 10.1016/S1672-6308(13)60124-9

Chou, T. S., Chao, Y. Y., Huang, W. D., Hong, C. Y., and Kao, C. H. (2011). Effect of magnesium deficiency on antioxidant status and cadmium toxicity in rice seedlings. J. Plant Physiol. 168, 1021-1030. doi: 10.1016/j.jplph.2010.12.004

Choudhary, S. P., Kanwar, M., Bhardwaj, R., Yu, J. Q., and Tran, L. S. P. (2012b). Chromium stress mitigation by polyamine-brassinosteroid application involves 
phytohormonal and physiological strategies in Raphanus sativus L. PLoS ONE 7:e33210. doi: 10.1371/journal.pone.0033210

Choudhary, S. P., Oral, H. V., Bhardwaj, R., Yu, J. Q., and Tran, L. S. P. (2012a). Interaction of brassinosteroids and polyamines enhances copper stress tolerance in Raphanus sativus. J. Exp. Bot. 63, 5659-5675. doi: $10.1093 / \mathrm{jxb} / \mathrm{ers} 219$

Cobbett, C. S. (2000). Phytochelatin biosynthesis and function in heavy-metal detoxification. Curr. Opin. Plant Biol. 3, 211-216. doi: 10.1016/S13695266(00)00066-2

Cobbett, C., and Goldsbrough, P. (2002). Phytochelatins and metallothioneins: roles in heavy metal detoxification and homeostasis. Annu. Rev. Plant Biol. 53, 159-182. doi: 10.1146/annurev.arplant.53.100301.135154

Collin, V. C., Eymery, F., Genty, B., Rey, P., and Havaux, M. (2008). Vitamin E is essential for the tolerance of Arabidopsis thaliana to metal induced oxidative stress. Plant Cell Environ. 31, 244-257. doi: 10.1111/j.1365-3040.2007.01755.x

Creissen, G., Edwards, E. A., Enard, C., Wellburn, A., and Mullineaux, P. (1992). Molecular characterisation of glutathione reductase cDNAs from pea (Pisum sativum L.). Plant J. 2, 129-131.

Cui, Y., Zhang, X., and Zhu, Y. (2008). Does copper reduce cadmium uptake by different rice genotypes? J. Environ. Sci. 20, 332-338. doi: 10.1016/S10010742(08)60052-2

Cui, F., Liu, L., Zhao, Q., Zhang, Z., Li, Q., Lin, B., et al. (2012a). Arabidopsis ubiquitin conjugase UBC32 is an ERAD component that functions in brassinosteroid-mediated salt stress tolerance. Plant Cell 24, 233-244. doi: 10.1105/tpc.111.093062

Cui, W., Li, L., Gao, Z., Wu, H., Xie, Y., and Shen, W. (2012b). Haem oxygenase-1 is involved in salicylic acid-induced alleviation of oxidative stress due to cadmium stress in Medicago sativa. J. Exp. Bot. 63, 5521-5534. doi: 10.1093/jxb/ers201

Curie, C., Alonso, J. M., Le Jean, M., Ecker, J. R., and Briat, J. F. (2000). Involvement of NRAMP1 from Arabidopsis thaliana in iron transport. Biochem. J. 347, 749-755. doi: 10.1042/bj3470749

Dalcorso, G., Fasani, E., and Furini, A. (2013b). Recent advances in the analysis of metal hyperaccumulation and hypertolerance in plants using proteomics. Front. Plant Sci. 4:280. doi: 10.3389/fpls.2013.00280

DalCorso, G., Manara, A., and Furini, A. (2013a). An overview of heavy metal challenge in plants: from roots to shoots. Metallomics 5, 1117-1132. doi: $10.1039 / \mathrm{c} 3 \mathrm{mt} 00038 \mathrm{a}$

Davidson, J. F., and Schiestl, R. H. (2001). Mitochondrial respiratory electron carriers are involved in oxidative stress during heat stress in Saccharomyces cerevisiae. Mol. Cell. Biol. 21, 8483-8489. doi: 10.1128/MCB.21.24.84838489.2001

Davletova, S., Rizhsky, L., Liang, H., Shengqiang, Z., Oliver, D. J., Coutu, J., et al. (2005). Cytosolic ascorbate peroxidase 1 is a central component of the reactive oxygen gene network of Arabidopsis. Plant Cell 17, 268-281. doi: $10.1105 /$ tpc. 104.026971

Delhaize, E., Gruber, B. D., Pittman, J. K., White, R. G., Leung, H., Miao, Y., et al. (2007). A role for the AtMTP11 gene of Arabidopsis in manganese transport and tolerance. Plant J. 51, 198-210. doi: 10.1111/j.1365-313X.2007.03138.x

Delhaize, E., Kataoka, T., Hebb, D. M., White, R. G., and Ryan, P. R. (2003), Genes encoding proteins of the cation diffusion facilitator family that confer manganese tolerance. Plant Cell 15, 1131-1142. doi: 10.1105/tpc.009134

Desbrosses-Fonrouge, A. G., Voigt, K., Schröder, A., Arrivault, S., Thomine, S., and Krämer, U. (2005). Arabidopsis thaliana MTP1 is a $\mathrm{Zn}$ transporter in the vacuolar membrane which mediates $\mathrm{Zn}$ detoxification and drives leaf $\mathrm{Zn}$ accumulation. FEBS Lett. 579, 4165-4174. doi: 10.1016/j.febslet.2005.06.046

Diáz, J., Bernal, A., Po Mar, F., and Merino, F. (2001). Induction of shikimate dehydrogenase and peroxidase in pepper (Capsicum annum L.) seedlings in response to copper stress and its relation to lignification. Plant Sci. 161, 179. doi: 10.1016/S0168-9452(01)00410-1

Divi, U. K., and Krishna, P. (2009). Brassinosteroid: a biotechnological target for enhancing crop yield and stress tolerance. New Biotechnol. 26, 131-136. doi: 10.1016/j.nbt.2009.07.006

Dixit, P., Mukherjee, P. K., Ramachandran, V., and Eapen, S. (2011). Glutathione transferase from Trichoderma virens enhances cadmium tolerance without enhancing its accumulation in transgenic Nicotiana tabacum. PLoS ONE 6:e16360. doi: 10.1371/journal.pone.0016360

Dixon, W. J., Inouye, C., Karin, M., and Tullius, T. D. (1996). CUP2 binds in a bipartite manner to upstream activation sequence $c$ in the promoter of the yeast copper metallothionein gene. J. Biol. Inorg. Chem. 1, 451-459. doi: $10.1007 / \mathrm{s} 007750050078$

Doncheva, S., Ameńos, M., Poschenrieder, C., and Barceĺo, J. (2005). Root cell patterning: a primary target for aluminium toxicity in maize. J. Exp. Bot. 56, 1213-1220. doi: 10.1093/jxb/eri115

Dong, J., Wu, F. B., and Zhang, G. P. (2005). Effect of cadmium on growth and photosynthesis of tomato seedlings. J. Zhejiang Univ. Sci. B 6, 974-980. doi: 10.1631/jzus.2005.B0974

Dräger, D. B., Desbrosses-Fonrouge, A. G., Krach, C., Chardonnens, A. N., Meyer, R. C., Saumitou-Laprade, P., et al. (2004). Two genes encoding Arabidopsis halleri MTP1 metal transport proteins co-segregate with zinc tolerance and account for high MTP1 transcript levels. Plant J. 39, 425-439. doi: 10.1111/j.1365-313X.2004.02143.x

Dragišić Maksimović, J., Mojović, M., Maksimović, V., Römheld, V., and Nikolic, M. (2012). Silicon ameliorates manganese toxicity in cucumber by decreasing hydroxyl radical accumulation in the leaf apoplast. J. Exp. Bot. 63, 2411-2420. doi: $10.1093 / \mathrm{jxb} / \mathrm{err} 359$

Duan, G.-L., Zhou, Y., Tong, Y.-P., Mukhopadhyay, R., Rosen, B. P., and Zhu, Y.G. (2007). A CDC25 homologue from rice functions as an arsenate reductase. New Phytol. 174, 311-321. doi: 10.1111/j.1469-8137.2007.02009.x

Eapen, S., and D'Souza, S. F. (2005). Prospects of genetic engineering of plants for phytoremediation of toxic metal. Biotechnol. Adv. 23, 97-114. doi: 10.1016/j.biotechadv.2004.10.001

Eide, D., Broderius, M., Fett, J., and Guerinot, M. L. (1996). A novel iron-regulated metal transporter from plants identified by functional expression in yeast. Proc. Natl. Acad. Sci. U.S.A. 93, 5624-5628. doi: 10.1073/pnas.93.11.5624

Elbaz, B., Shoshani-Knaani, N., David-Assael, O., Mizrachy-Dagri, T., Mizrahi, K., Saul, H., et al. (2006). High expression in leaves of the zinc hyperaccumulator Arabidopsis halleri of AhMHX, a homolog of an Arabidopsis thaliana vacuolar metal/protonexchanger. Plant Cell Environ. 29, 1179-1190. doi: 10.1111/j.13653040.2006.01500.x

Eleftheriou, E. P., Adamakis, I. D., and Melissa, P. (2012). Effects of hexavalent chromium on microtubule organization, ER distribution and callose deposition in root tip cells of Allium cepa L. Protoplasma 249, 401-416. doi: 10.1007/s00709-011-0292-3

Ellis, D. R., Gumaelius, L., Indriolo, E., Pickering, I. J., Banks, J. A., and Salt, D. E. (2006). A novel arsenate reductase from the arsenic hyperaccumulating fern Pteris vittata. Plant Physiol. 141, 1544-1554. doi: 10.1104/pp.106.084079

Epstein, E. (1999). Silicon. Annu. Rev. Plant Physiol. Plant Mol. Biol. 50, 641-664. doi: 10.1146/annurev.arplant.50.1.641

Ernst, W. H. O. (2006). Evolution of metal tolerance in higher plants. For. Snow Landsc. Res. 80, 251-274. Available online at: http://www.wsl.ch/ dienstleistungen/publikationen/pdf/7764.pdf

Ernst, W. H. O., Krauss, G. J., Verkleij, J. A. C., and Wesenberg, D. (2008) Interaction of heavy metal with the sulphur metabolism in angiosperms from an ecological point of view. Plant Cell Environ. 31, 123-143. doi: 10.1111/j.1365-3040.2007.01746.x

Esposito, S., Sorbo, S., Conte, B., and Basile, A. (2012). Effects of heavy metal on ultrastructure and HSP70s induction in the aquatic moss Leptodictyum riparium Hedw. Int. J. Phytoremediation 14, 443-455. doi: 10.1080/15226514.2011.620904

Fahr, M., Laplaze, L., Bendaou, N., Hocher, V., Mzibri, M. E., Bogusz, D. et al. (2013). Effect of lead on root growth. Front. Plant Sci. 4:175. doi: $10.3389 /$ fpls.2013.00175

FAO (2012). Statistical Yearbook Viale delle Terme di Caracalla. Rome.

Farias, J. G., Antes, F. L. G., Nunes, P. A. A., Nunes, S. T., Schaich, G., Rossato, L. V., et al. (2013). Effects of excess copper in vineyard soils on the mineral nutrition of potato genotypes. Food Energy Security 2, 49-69. doi: 10.1002/fes3.16

Fariduddin, Q., Yusuf, M., Hayat, S., and Ahmad, A. (2009). Effect of 28homobrassinolide on antioxidant capacity and photosynthesis in Brassica juncea plants exposed to different levels of copper. Environ. Exp. Bot. 66, 418-424. doi: 10.1016/j.envexpbot.2009.05.001

Farzadfar, S., Zarinkamar, F., Modarres-Sanavy, S. A. M., and Hojati, M. (2013). Exogenously applied calcium alleviates cadmium toxicity in Matricaria chamomilla L. Plants Environ. Sci. Pollut. Res. 20, 1413-1422. doi: 10.1007/s11356-012-1181-9

Feng, R. W., and Wei, C. Y. (2012). Antioxidative mechanisms on selenium accumulation in Pteris vittata L., a potential selenium phytoremediation 
plant. Plant Soil Environ. 58, 105-110. Available online at: http://www. agriculturejournals.cz/publicFiles/61470.pdf

Feng, R. W., Wei, C. Y., Tu, S. X., Tang, S. R., and Wu, F. C. (2011). Detoxification of antimony by selenium and their interaction in paddy rice under hydroponic conditions. Microchem. J. 97, 57-61. doi: 10.1016/j.microc.2010.06.003

Ferretti, M., Ghisi, R., Merlo, L., Dalla Vecchia, F., and Passera, C. (1993). Effect of cadmium on photosynthesis and enzymes of photosynthetic sulfate and nitrate assimilation pathways in maize (Zea mays L.). Photosynthetica 29, 49-54.

Fidalgo, F., Azenha, M., Silva, A. F., de Sousa, A., Santiago, A., Ferraz, P., et al. (2013). Copper-induced stress in Solanum nigrum L. and antioxidant defense system responses. Food Energy Security 2, 70-80. doi: 10.1002/fes3.20

Filek, M., Keskinen, R., Hartikainen, H., Szarejko, I., Janiak, A., Miszalski, Z., et al. (2008). The protective role of selenium in rape seedlings subjected to cadmium stress. J. Plant Physiol. 165, 833-844. doi: 10.1016/j.jplph.2007.06.006

Fontes, R. L. S., and Cox, F. R. (1998). Zinc toxicity in soybean grown at high iron concentration in nutrient solution. J. Plant Nutr. 21, 1723-1730. doi: 10.1080/01904169809365517

Foreman, J., Demidchik, V., Bothwell, J. H., Mylona, P., Miedema, H., Torres, M. A., et al. (2003). Reactive oxygen species produced by NADPH oxidase regulate plant cell growth. Nature 422, 442-446. doi: 10.1038/nature01485

Foyer, C. H., and Halliwell, B. (1976). Presence of glutathione and glutathione reductase in chloroplasts: a proposed role in ascorbic acid metabolism. Planta 133, 21-25. doi: 10.1007/BF00386001

Foyer, C. H., Lopez-Delgado, H., Dat, J. F., and Scott, I. M. (1997). Hydrogen peroxide and glutathione-associated mechanisms of acclamatory stress tolerance and signalling. Physiol. Plant. 100, 241-254. doi: 10.1111/j.13993054.1997.tb04780.x

Freeman, J. L., and Salt, D. E. (2007). The metal tolerance profile of Thlaspi goesingense is mimicked in Arabidopsis thaliana heterologously expressing serine acetyl-transferase. BMC Plant Biol. 7:63. doi: 10.1186/14712229-7-63

Freeman, J. L., Garcia, D., Kim, D., Hopf, A., and Salt, D. E. (2005a). Constitutively elevated salicylic acid signals glutathione-mediated nickel tolerance in Thlaspi nickel hyperaccumulators. Plant Physiol. 137, 1082-1091. doi: $10.1104 /$ pp.104.055293

Freeman, J. L., Persans, M. W., Nieman, K., Albrecht, C., Peer, W., Pickering, I. J., et al. (2004). Increased glutathione biosynthesis plays a role in nickel tolerance in Thlaspi nickel hyperaccumulators. Plant Cell 16, 2176-2191. doi: 10.1105/tpc.104.023036

Freeman, J. L., Persans, M. W., Nieman, K., and Salt, D. E. (2005b). Nickel and cobalt resistance engineered in Escherichia coli by overexpression of serine acetyltransferase from the nickel hyperaccumulator plant Thlaspi goesingense. Appl. Environ. Microbiol. 71, 8627-8633. doi: 10.1128/AEM.71.12.86278633.2005

Frérot, H., Faucon, M. P., Willems, G., Godé, C., Courseaux, A., Darracq, A., et al. (2010). Genetic architecture of zinc hyperaccumulation in Arabidopsis halleri: the essential role of QTLx environment interactions. New Phytol. 187, 355-367. doi: $10.1111 /$ j.1469-8137.2010.03295.x

Fridovich, I. (1989). Superoxide dismutases: an adaptation to paramagnetic gas. J. Biol. Chem. 264, 7761-7764.

Führs, H., Behrens, C., Gallien, S., Heintz, D., Van Dorsselaer, A., Braun, H. P., et al. (2010). Physiological and proteomic characterization of manganese sensitivity and tolerance in rice (Oryza sativa) in comparison with barley (Hordeum vulgare). Ann. Bot. 105, 1129-1140. doi: 10.1093/aob/mcq046

Führs, H., Hartwig, M., Molina, L. E., Heintz, D., Van Dorsselaer, A., Braun, H. P., et al. (2008). Early manganese-toxicity response in Vigna unguiculata L. a proteomic and transcriptomic study. Proteomics 8, 149-159. doi: 10.1002/pmic.200700478

Fukao, Y., Ferjani, A., Tomioka, R., Nagasaki, N., Kurata, R., Nishimori, Y., et al. (2011). iTRAQ analysis reveals mechanisms of growth defects due to excess zinc in Arabidopsis. Plant Physiol. 155, 1893-1907. doi: 10.1104/pp.110.169730

Fürst, P., Hu, S., Hackett, R., and Hamer, D. (1988). Copper activates metallothionein gene transcription by altering the conformation of a specific DNA binding protein. Cell 55, 705-717. doi: 10.1016/0092-8674(88)90229-2

Galeas, M. L., Zhang, L. H., Freeman, J. L., Wegner, M., and Pilon-Smits, E. A. H. (2007). Seasonal fluctuations of selenium and sulphur accumulation in selenium hyperaccumulators and related nonaccumulators. New Phytol. 173, 517-525. doi: 10.1111/j.1469-8137.2006.01943.x
Gangwar, S., and Singh, V. P. (2011). Indole acetic acid differently changes growth and nitrogen metabolism in Pisum sativum L. seedlings under chromium (VI) phytotoxicity: implication of oxidative stress. Sci. Hortic. 129, 321-328. doi: 10.1016/j.scienta.2011.03.026

Gangwar, S., Singh, V. P., Prasad, S. M., and Maurya, J. N. (2010). Modulation of manganese toxicity in Pisum sativum L. seedlings by kinetin. Sci. Hortic. 126, 467-474. doi: 10.1016/j.scienta.2010.08.013

Gangwar, S., Singh, V. P., Srivastava, P. K., and Maurya, J. N. (2011). Modification of chromium (VI) phytotoxicity by exogenous gibberellic acid application in Pisum sativum (L.) seedlings. Acta Physiol. Plant. 33, 1385-1397. doi: 10.1007/s11738-010-0672-x

Gao, J., Sun, L., Yang, X., and Liu, J. X. (2013). Transcriptomic analysis of cadmium stress response in the heavy metal hyperaccumulator Sedum alfredii Hance. PLoS ONE 8:e64643. doi: 10.1371/journal.pone.0064643

Garzón, T., Gunsé, B., Moreno, A. R., Tomos, A. D., Barceló, J., and Poschenrieder, C. (2011). Aluminium-induced alteration of ion homeostasis in root tip vacuoles of two maize varieties differing in Al tolerance. Plant Sci. 180, 709-715. doi: 10.1016/j.plantsci.2011.01.022

Ghosh, M., Shen, J., and Rosen, B. P. (1999). Pathways of As(III) detoxification in Saccharomyces cerevisiae. Proc. Natl. Acad. Sci. U.S.A. 96, 5001-5006. doi: 10.1073/pnas.96.9.5001

Gichner, T., Patkova, Z., Szakova, J., and Demnerova, K. (2004). Cadmium induces DNA damages in tobacco roots, but no DNA damage, somatic mutations orhomologous recombinations in tobacco leaves. Mutat. Res. Genet. Toxicol. Environ. Mut. 559, 49-57. doi: 10.1016/j.mrgentox.2003. 12.008

Gill, S. S., Hasanuzzaman, M., Nahar, K., Macovei, A., and Tuteja, N. (2013). Importance of nitric oxide in cadmium stress tolerance in crop plants. Plant Physiol. Biochem. 63, 254-261. doi: 10.1016/j.plaphy.2012.12.001

Gomes, M. M. A. (2011). "Physiological effects related to brassinosteroid application in plants," in Brassinosteroids: A Class of Plant Hormone, eds S. Hayat and A. Ahmad (Dordrecht: Springer), 193-242. doi: 10.1007/978-94007-0189-2_7

Grennan, A. K. (2009). Identification of genes involved in metal transport in plants. Plant Physiol. 149, 1623-1624. doi: 10.1104/pp.109.900287

Guan, Z., Chai, T., Zhang, Y., Xu, J., and Wei, W. (2009). Enhancement of Cd tolerance in transgenic tobacco plants overexpressing a Cd-induced catalase cDNA. Chemosphere 76, 623-630. doi: 10.1016/j.chemosphere.2009. 04.047

Guo, B., Liang, Y., and Zhu, Y. (2009). Does salicylic acid regulate antioxidant defense system, cell death, cadmium uptake and partitioning to acquire cadmium tolerance in rice? J. Plant Physiol. 166, 20-31. doi: 10.1016/j.jplph.2008.01.002

Guo, J., Dai, X., Xu, W., and Ma, M. (2008a). Overexpressing GSHI and AsPCSI simultaneously increases the tolerance and accumulation of cadmium and arsenic in Arabidopsis thaliana. Chemosphere 72, 1020-1026. doi: 10.1016/j.chemosphere.2008.04.018

Guo, W. J., Meetam, M., and Goldsbrough, P. (2008b). Examining the specific contributions of individual Arabidopsis metallothioneins to copper distribution and metal tolerance. Plant Physiol. 164, 1697-1706. doi: 10.1104/pp.108.115782

Gustin, J. L., Zanis, M. J., and Salt, D. E. (2011). Structure and evolution of the plant cation diffusion facilitator family of ion transporters. BMC Evol. Biol. 11:76. doi: 10.1186/1471-2148-11-76

Gygi, S. P., Rochon, Y., Franza, B. R., and Aebersold, R. (1999). Correlation between protein and mRNA abundance in yeast. Mol. Cell. Biol. 19, 1720-1730. doi: 10.1128/MCB.19.3.1720

Haag-Kerwer, A., Schäfer, H. J., Heiss, S., Walter, C., and Rausch, T. (1999). Cadmium exposure in Brassica juncea causes a decline in transpiration rate and leaf expansion without effect on photosynthesis. J. Exp. Bot. 50, 1827-1835. doi: $10.1093 / \mathrm{jxb} / 50.341 .1827$

Hajduch, M., Rakwal, R., Agrawal, G. K., Yonekura, M., and Pretova, A. (2001). High-resolution two-dimensional electrophoresis separation of proteins from metal-stressed rice (Oryza sativa L.) leaves: drastic reductions/fragmentation of ribulose-1,5-bisphosphate carboxylase/oxygenase and induction of stress-related proteins. Electrophoresis 22, 2824-2831. doi: 10.1002/1522-2683(200108)22:13<2824::AID-ELPS2824>3.0.CO;2-C

Hall, J. L., and Williams, L. E. (2003). Transition metal transporters in plants. J. Exp. Bot. 54, 2601-2613. doi: 10.1093/jxb/erg303 
Halliwell, B. (2006). Reactive species and antioxidants. Redox biology is a fundamental theme of aerobic life. Plant Physiol. 141, 312-322. doi: 10.1104/pp.106.077073

Hamayun, M., Khan, S. A., Khan, A. L., Shin, J. H., Ahmad, B., and Shin, D. H. (2010). Exogenous gibberellic acid reprograms soybean to higher growth and salt stress tolerance. J. Agric. Food Chem. 58, 7226-7232. doi: 10.1021/jf101221t

Hamer, D. H. (1986). Metallothionein. Annu. Rev. Biochem. 55, 913-951. doi: 10.1146/annurev.bi.55.070186.004405

Haney, C. J., Grass, G., Franke, S., and Rensing, C. (2005). New developments in the understanding of the cation diffusion facilitator family. J. Ind. Microbiol. Biotechnol. 32, 215-226. doi: 10.1007/s10295-005-0224-3

Hao, J., Yin, Y., and Fei, S. Z. (2013). Brassinosteroid signaling network: implications on yield and stress tolerance. Plant Cell Rep. 32, 1017-1030. doi: 10.1007/s00299-013-1438-x

Harrison, P. M., and Arosio, P. (1996). The ferritins: molecular properties, iron storage function and cellular regulation. Biochim. Biophys. Acta 275, 161-203. doi: 10.1016/0005-2728(96)00022-9

Hart, J. J., Welch, R. M., Norvell, W. A., Clarke, J. M., and Kochian, L. V. (2005). Zinc effects on cadmium accumulation and partitioning in near isogenic lines of durum wheat that differ in grain cadmium concentration. New Phystol. 167, 391-401. doi: 10.1111/j.1469-8137.2005.01416.x

Hassan, M. J., Zhang, G., Wu, F., Wei, K., and Chen, Z. (2005). Zinc alleviates growth inhibition and oxidative stress caused by cadmium in rice. J. Plant Nutr. Soil Sci. 168, 255-261. doi: 10.1002/jpln.200420403

Hayat, Q., Hayat, S., Irfan, M., and Ahmad, A. (2010). Effect of exogenous salicylic acid under changing environment: a review. Environ. Exp. Bot. 68, 14-25. doi: 10.1016/j.envexpbot.2009.08.005

Hayat, S., Ali, B., Aiman Hasan, S., and Ahmad, A. (2007). Brassinosteroid enhanced the level of antioxidants under cadmium stress in Brassica juncea. Environ. Exp. Bot. 60, 33-41. doi: 10.1016/j.envexpbot.2006.06.002

Hayat, S., Khalique, G., Irfan, M., Wani, A. S., Tripathi, B. N., and Ahmad, A. (2012). Physiological changes induced by chromium stress in plants: an overview. Protoplasma 249, 599-611. doi: 10.1007/s00709-011-0331-0

He, H., Zhan, J., He, L., and Gu, M. (2012). Nitric oxide signaling in aluminum stress in plants. Protoplasma 249, 483-492. doi: 10.1007/s00709-0110310-5

He, P. P., Lv, X. Z., and Wang, G. Y. (2004). Effects of Se and Zn supplementation on the antagonism against $\mathrm{Pb}$ and $\mathrm{Cd}$ in vegetables. Environ. Int. 30, 167-172. doi: $10.1016 / S 0160-4120(03) 00167-3$

Herbette, S., Taconnat, L., Hugouvieux, V., Piette, L., Magniette, M. L., Cuine, S., et al. (2006). Genome-wide transcriptome profiling of the early cadmium response of Arabidopsis roots and shoots. Biochimie 88, 1751-1765. doi: 10.1016/j.biochi.2006.04.018

Herbik, A., Giritch, A., Horstmann, C., Becker, R., Balzer, H. J., Bäumlein, H., et al. (1996). Iron and copper nutrition-dependent changes in protein expression in a tomato wild type and the nicotianamine-free mutant chloronerva. Plant Physiol. 111, 533-540. doi: 10.1104/pp.111.2.533

Hernández, L. E., Garate, A., and Carpena-Ruiz, R. (1997). Effects of cadmium on the uptake, distribution and assimilation of nitrate in Pisum sativum. Plant Soil. $189,97-106$.

Hernandez, L. E., Villasante, C. O., Montero-Palmero, M. B., Escobar, C., and Carpena, R. O. (2012). "Heavy metal perception in a microscale environment: a model system using high doses of pollutants," in Metal Toxicity in Plants: Perception, Signaling and Remediation, eds D. K. Gupta and L. M. Sandalio (Berlin; Heidelberg: Springer-Verlag), 23-37. doi: 10.1007/978-3-642-22081$4 \_2$

Hirata, K., Tsuji, N., and Miyamoto, K. (2005). Biosynthetic regulation of phytochelatins, heavy metal-binding peptides. J. Biosci. Bioeng. 100, 593-599. doi: $10.1263 / j b b .100 .593$

Hirschi, K. D., Korenkov, V. D., Wilganowski, N. L., and Wagner, G. J. (2000). Expression of Arabidopsis CAX2 in tobacco. Altered metal accumulation and increased manganese tolerance. Plant Physiol. 124, 125-133. doi: 10.1104/pp.124.1.125

Hisamatsu, T., Koshioka, M., Kubota, S., Fujime, Y., King, R. W., and Mander, L. N. (2000). The role of gibberellin in the control of growth and flowering in Matthiola incana. Physiol. Plant. 109, 97-105. doi: 10.1034/j.13993054.2000.100114.x

Horváth, E., Szalai, G., and Janda, T. (2007). Induction of abiotic stress tolerance by salicylic acid signaling. J. Plant Growth Regul. 26, 290-300. doi: 10.1007/s00344007-9017-4
Hossain, M. A., Hasanuzzaman, M., and Fujita, M. (2011). Coordinate induction of antioxidant defense and glyoxalase system by exogenous proline and glycinebetaineis correlated with salt tolerance in mung bean. Front. Agric. China 5, 1-14. doi: 10.1007/s11703-010-1070-2

Hossain, M. A., Hossain, M. D., Rohman, M. M., da Silva, J. A. T., and Fujita, M. (2012b). "Onion major compounds (flavonoids, organosulfurs) and highly expressed glutathione-related enzymes: possible physiological interaction, gene cloning and abiotic stress response," in Onion Consumption and Health, eds C. B. Aguirre and L. M. Jaramillo (New York, NY: Nova Science Publishers), 49-90.

Hossain, M. A., Piyatida, P., da Silva, J. A. T., and Fujita, M. (2012a). Molecular mechanism of heavy metal toxicity and tolerance in plants: central role of glutathione in detoxification of reactive oxygen species and methylglyoxal and in heavy metal chelation. J. Bot. 2012:872875. doi: 10.1155/2012/ 872875

Hossain, Z., and Komatsu, S. (2013). Contribution of proteomic studies towards understanding plant heavy metal tress response. Front. Plant Sci. 3:310. doi: $10.3389 /$ fpls.2012.00310

Hossain, Z., Nouri, M. Z., and Komatsu, S. (2012c). Plant cell organelle proteomics in response to abiotic stress. J. Proteome Res. 11, 37-48. doi: 10.1021/ pr200863r

Howarth, J. R., Domínguez-Solís, J. R., Gutíerrez-Alcalá, G., Wray, J. L., Romero, L. C., and Gotor, C. (2003). The serine acetyltransferase gene family in Arabidopsis thaliana and the regulation of its expression by cadmium. Plant Mol. Biol. 51, 589-598. doi: 10.1023/A:1022349623951

Husaini, Y., and Rai, L. C. (1991). Studies on nitrogen and phosphorus metabolism and the photosynthetic electron transport system of Nostoc linckia under cadmium stress. J. Plant Physiol. 138, 429-435. doi: 10.1016/S01761617(11)80518-3

Hussain, D., Haydon, M. J., Wang, Y., Wong, E., Sherson, S. M., Young, J., et al. (2004). P-Type ATPase heavy metal transporters with roles in essential zinc homeostasis in Arabidopsis. Plant Cell 16, 1327-1339. doi: 10.1105/tpc.020487

Imran, M. A., Ch, M. N., Khan, R. M., Ali, Z., and Mahmood, T. (2013). Toxicity of arsenic (As) on seed germination of sunflower (Helianthus annuus L.). Int. J. Phys. Sci. 8, 840-847. doi: 10.5897/IJPS2013.3894

Indriolo, E., Na, G., Ellis, D., Salt, D. E., and Banks, J. A. (2010). A vacuolar arsenite transporter necessary for arsenic tolerance in the arsenic hyperaccumulating fern Pteris vittata is missing in flowering plants. Plant Cell 22, 2045-2057. doi: $10.1105 /$ tpc. 109.069773

Ingle, R. A., Smith, J. A., and Sweetlove, L. J. (2005). Responses to nickel in the proteome of the hyperaccumulator plant Alyssum lesbiacum. Biometal 18, 627-641. doi: 10.1007/s10534-005-2999-0

Iqbal, N., Nazar, R., Khan, M. I. R., Masood, A., and Khan, N. A. (2011). Role of gibberellins in regulation of source-sink relations under optimal and limiting environmental conditions. Curr. Sci. 100, 998-1007. Available online at: http:// www.currentscience.ac.in/Volumes/100/07/0998.pdf

Israr, M., Sahi, S., Datta, R., and Sarkar, D. (2006). Bioaccumulation and physiological effects of mercury in Sesbania drummonii. Chemosphere 65, 591-598. doi: 10.1016/j.chemosphere.2006.02.016

Iuchi, S., Koyama, H., Iuchi, A., Kobayashi, Y., Kitabayashi, S., Kobayashi, Y., et al. (2007). Zinc finger protein STOP1 is critical for proton tolerance in Arabidopsis and coregulates a key gene in aluminum tolerance. Proc. Natl. Acad. Sci. U.S.A. 104, 9900-9905. doi: 10.1073/pnas.0700117104

Jalloh, M. A., Chen, J., Zhen, F., and Zhang, G. (2009). Effect of different N fertilizer forms on anti-oxidant capacity and grain yield of rice growing under Cd stress. J. Hazard. Mater. 162, 1081-1085. doi: 10.1016/j.jhazmat.2008. 05.146

Janeckzo, A., Koscielniak, J., Pilipowicz, M., Szarek-Lukaszewska, G., and Skoczowski, A. (2005). Protection of winter rape photosystem 2 by 24epibrassinolide under cadmium stress. Photosynthetica 43, 293-298. doi: 10.1007/s11099-005-0048-4

Janicka-Russak, M., Kabała, K., Burzyński, M., and Kłobus, G. (2008). Response of plasma membrane $\mathrm{H}^{+}$-ATPase to heavy metal stress in Cucumis sativus roots. J. Exp. Bot. 59, 3721-3728. doi: 10.1093/jxb/ern219

Jarup, L. (2003). Hazards of heavy metal contamination. Br. Med. Bull. 68, 167-182. doi: $10.1093 / \mathrm{bmb} / \mathrm{ldg} 032$

Jewell, M. C., Campbell, B. C., and Godwin, I. D. (2010). "Transgenic plants for abiotic stress resistance," in Transgenic Crop Plants, eds C. Kole, C. H. Michler, A. G. Abbott, and T. C. Hall (Berlin; Heidelberg: Springer-Verlag), 67-31. doi: 10.1007/978-3-642-04812-8_2 
Jonak, C., Nakagami, H., and Hirt, H. (2004). Heavy metal stress. Activation of distinct mitogen-activated protein kinase pathways by copper and cadmium. Plant Physiol. 136, 3276-3283. doi: 10.1104/pp.104.045724

Jonak, C., Okrész, L., Bögre, L., and Hirt, H. (2002). Complexity, cross talk and integration of plant MAP kinase signalling. Curr. Opin. Plant Biol. 5, 415-424. doi: 10.1016/S1369-5266(02)00285-6

Jun, M., Fu, H. Y., Hong, J., Wan, X., Yang, C. S., and Ho, C. T. (2003). Comparison ofantioxidant activities of isoflavones from kudzu root (PuerarialobataOhwi). J. Food Sci. 68, 2117-2122. doi: 10.1111/j.1365-2621.2003.tb07029.x

Kagale, S., Divi, U. K., Krochko, J. E., Keller, W. A., and Krishna, P. (2007). Brassinosteroid confers tolerance in Arabidopsis thaliana and Brassica napus to a range of abiotic stresses. Planta 225, 353-364. doi: 10.1007/s00425-0060361-6

Kanoun-Boulé, M., Vicente, J. A., Nabais, C., Prasad, M. N. V., and Freitas, H. (2009). Ecophysiological tolerance of duckweeds exposed to copper. Aquat. Toxicol. 91, 1-9. doi: 10.1016/j.aquatox.2008.09.009

Kavamura, V. N., and Esposito, E. (2010). Biotechnological strategies applied to the decontamination of soils polluted with heavy metal. Biotechnol. Adv. 28, 61-69. doi: 10.1016/j.biotechadv.2009.09.002

Kenderešová, L., Staňová, A., Pavlovkin, J., Ďurišová, E., Nadubinská, M., Ciamporová, M., et al. (2012). Early $\mathrm{Zn}^{2+}$-induced effects on membrane potential account for primary heavy metal susceptibility in tolerant and sensitive Arabidopsis species. Ann. Bot. 110, 445-459. doi: 10.1093/aob/mcs111

Kerkeb, L., and Krämer, U. (2003). The role of free histidine in xylem loading of nickel in Alyssum lesbiacum and Brassica juncea. Plant Physiol. 131, 716-724. doi: 10.1104/pp102.010686

Keunen, E., Remans, T., Bohler, S., Vangronsveld, J., and Cuypers, A. (2011). Metalinduced oxidative stress and plant mitochondria. Int. J. Mol. Sci. 12, 6894-6918. doi: $10.3390 /$ ijms 12106894

Khan, A. L., and Lee, I. J. (2013). Endophytic Penicillium funiculosum LHL06 secretes gibberellin that reprograms Glycine max L. growth during copper stress. BMC Plant Biol. 13:86. doi: 10.1186/1471-2229-13-86

Khan, N. A., Anjum, N. A., Nazar, R., and Iqbal, N. (2009). Increased activity of ATP-sulfurylase and increased contents of cysteine and glutathione reduce high cadmium- induced oxidative stress in mustard cultivar with high photosynthetic potential. Russ. J. Plant Physiol. 56, 670-677. doi: $10.1134 / \mathrm{S} 1021443709050136$

Khan, N. A., Samiullah Singh, S., and Nazar, R. (2007). Activities of antioxidative enzymes, sulphur assimilation, photosynthetic activity and growth of wheat (Triticum aestivum) cultivars differing in yield potential under cadmium stress. J. Agron. Crop Sci. 193, 435-444. doi: 10.1111/j.1439-037X.2007.00272.x

Khattak, R. A., Page, A. L., Parker, D. R., and Bakhtar, D. (1991). Accumulation and interactions of arsenic, selenium, molybdenum and phosphorus in Alfalfa. J. Environ. Qual. 20, 165-168. doi: 10.2134/jeq1991.00472425002000010026x

Khripach, V., Zhabinskii, V., and De Groot, A. (2000). Twenty years of brassinosteroids: steroidal plant hormones warrant better crops for the XXI century. Ann. Bot. 86, 441-447. doi: 10.1006/anbo.2000.1227

Kieffer, P., Dommes, J., Hoffmann, L., Hausman, J. F., and Renaut, J. (2008). Quantitative changes in protein expression of cadmium-exposed poplar plants. Proteomics 8, 2514-2530. doi: 10.1002/pmic. 200701110

Kikui, S., Sasaki, T., Maekawa, M., Miyao, A., Hirochika, H., Matsumoto, H., et al. (2005). Physiological and genetic analyses of aluminium tolerance in rice, focusing on root growth during germination. J. Inorg. Biochem. 99, 1837-1844. doi: 10.1016/j.jinorgbio.2005.06.031

Kim, I. S., Shin, S. Y., Kim, Y. S., Kim, H. Y., and Yoon, H. S. (2009). Expression of a glutathione reductase from Brassica rapa subsp. pekinensis enhanced cellular redox homeostasis by modulating antioxidant proteins in Escherichia coli. Mol. Cells 28, 479-487. doi: 10.1007/s10059-009-0168-y

Klapheck, S., Schlunz, S., and Bergmann, L. (1995). Synthesis of phytochelatins and homo-phytochelatins in Pisum sativum L. Plant Physiol. 107, 515-521.

Kobae, Y., Uemura, T., Sato, M. H., Ohnishi, M., Mimura, T., Nakagawa, T., et al. (2004). Zinc transporter of Arabidopsis thaliana AtMTP1 is localized to vacuolar membranes and implicated in zinc homeostasis. Plant Cell Physiol. 45, 1749-1758. doi: 10.1093/pcp/pci015

Koprivova, A., North, K. A., and Kopriva, S. (2008). Complex signaling network in regulation of adenosine $5^{\prime}$-phosphosulfate reductase by salt stress in Arabidopsis roots. Plant Physiol. 146, 1408-1420. doi: 10.1104/pp.107.113175
Kosová K., Vítámvás, P., Prášil, I. T., and Renaut, J. (2011). Plant proteome changes under abiotic stress- contribution of proteomics studies to understanding plant stress response. J. Proteomics 74, 1301-1322. doi: 10.1016/j.jprot.2011.02.006

Kováčik, J., and Klejdus, B. (2008). Dynamics of phenolic acids and lignin accumulation in metal-treated Matricariachamomilla roots. Plant Cell Rep. 27, 605-615. doi: 10.1007/s00299-007-0490-9

Kováčik, J., Klejdus, B., and Bačkor, M. (2009). Phenolic metabolism of Matricariachamomilla plants exposed to nickel. J. Plant Physiol. 166, 1460-1464. doi: 10.1016/j.jplph.2009.03.002

Krämer, U. (2010). Metal hyperaccumulation in plants. Annu. Rev. Plant Biol. 61, 517-534. doi: 10.1146/annurev-arplant-042809-112156

Krämer, U., Cotter-Howells, J. D., Charnock, J. M., Baker, A. J. M., and Smith, J. A. C. (1996). Free histidine as a metal chelator in plants that accumulate nickel. Nature 379, 635-638. doi: 10.1038/379635a0

Krämer, U., Pickering, I. J., Prince, R. C., Raskin, I., and Salt, D. E. (2000). Subcellular localization and speciation of nickel in hyperaccumulator and non-accumulator Thlaspi species. Plant Physiol. 122, 1343-1354. doi: 10.1104/pp.122.4.1343

Krämer, U., Talke, I. N., and Hanikenne, M. (2007). Transition metal transport. FEBS Lett. 581, 2263-2272. doi: 10.1016/j.febslet.2007.04.010

Krantev, A., Yordanova, R., Janda, T., Szalai, G., and Popova, L. (2008). Treatment with salicylic acid decreases the effect of cadmium on photosynthesis in maize plants. J. Plant Physiol. 165, 920-931. doi: 10.1016/j.jplph.2006.11.014

Krishnamurti, G. S. R., Cieslinski, G., Huang, P. M., and Van Rees, K. C. J. (1997). Kinetics of cadmium release from soils as influenced by organic acids: implication in cadmium availability. J. Environ. Qual. 26, 271-277. doi: $10.2134 /$ jeq1997.00472425002600010038x

Kumar, A., Prasad, M. N. V., and Sytar, O. (2012). Lead toxicity, defense strategies and associated indicative biomarkers in Talinumtriangularegrown hydroponically. Chemosphere 89, 1056-1165. doi: 10.1016/j.chemosphere.2012.05.070

Kuriakose, S. V., and Prasad, M. N. V. (2008). Cadmium stress affects seed germination and seedling growth in Sorghum bicolor (L.) Moench by changing the activities of hydrolyzing enzymes. Plant Growth Regul. 54, 143-156. doi: 10.1007/s10725-007-9237-4

Kwak, J. M., Nguyen, V., and Schroeder, J. I. (2006). The role of reactive oxygen species in hormonal responses. Plant Physiol. 141, 323-329. doi: 10.1104/pp.106.079004

Lan, H. X., Wang, Z. F., Wang, Q. H., Wang, M. M., Bao, Y. M., Huang, J., et al. (2012). Characterization of a vacuolar zinc transporter OZT1 in rice (Oryza sativa L.). Mol. Biol. Rep. 40, 1201-1210. doi: 10.1007/s11033-012-2162-2

Landrieu, I., da Costa, M., De Veylder, L., Dewitte, F., Vandepoele, K., Hassan, S., et al. (2004a). A small CDC25 dual-specificity tyrosine-phosphatase isoform in Arabidopsis thaliana. Proc. Natl. Acad. Sci. U.S.A. 101, 13380-13385. doi: 10.1073/pnas. 0405248101

Landrieu, I., Hassan, S., Sauty, M., Dewitte, F., Wieruszeski, J. M., Inzé, D., et al. (2004b). Characterization of the Arabidopsis thaliana Arath;CDC25 dualspecificity tyrosine phosphatase. Biochem. Biophys. Res. Commun. 322, 734-739. doi: 10.1016/j.bbrc.2004.07.182

Lanquar, V., Lelièvre, F., Bolte, S., Hamès, C., Alcon, C., Neumann, D., et al. (2005). Mobilization of vacuolar iron by AtNRAMP3 and AtNRAMP4 is essential for seed germination on low iron. EMBO J. 24, 4041-4051. doi: 10.1038/sj.emboj.7600864

Lauer Júnior, C. M., Bonatto, D., Mielniczki-Pereira, A. A., Schuch, A. Z., Dias, J. F., Yoneama, M. L., et al. (2008). The Pmrl protein, the major yeast Ca2+ATPase in the grefecvolgi, regulates intracellular levels of the cadmium ion. FEMS Microbiol. Lett. 285, 79-88. doi: 10.1111/j.1574-6968.2008.01214.x

Lavid, N., Schwartz, A., Yar Den, O., and Tel-Or, E. (2001). The involvement of polyphenols and peroxidase acitivities in heavy metal accumulation by epidermal glands of water lily (Nymphaeceaea). Planta 212, 323. doi: $10.1007 / \mathrm{s} 004250000400$

Lea, P. J., and Miflin, B. J. (2004). Glutamate synthase and the synthesis of glutamate in plants. Plant Physiol. Biochem. 41, 555-564. doi: 10.1016/S09819428(03)00060-3

Le Martret, B., Poage, M., Shiel, K., Nugent, G. D., and Dix, P. J. (2011). Tobacco chloroplast transformants expressing genes encoding dehydroascorbate reductase, glutathione reductase, and glutathione-S-transferase, exhibit altered 
anti-oxidant metabolism and improved abiotic stress tolerance. Plant Biotechnol. J. 9, 661-673. doi: 10.1111/j.1467-7652.2011.00611.x

LeDuc, D. L., AbdelSamie, M., Móntes-Bayon, M., Wu, C. P., Reisinger, S. J., and Terry, N. (2006). Overexpressing both ATP sulfurylase and selenocysteine methyltransferase enhances selenium phytoremediation traits in Indian mustard. Environ. Poll. 144, 70-76. doi: 10.1016/j.envpol.2006.01.008

Lee, H., Jo, J., and Son, D. (1998). Molecular cloning and characterization of the gene encoding glutathione reductase in Brassica campestris. Biochim. Biophys. Acta 1395, 309-314. doi: 10.1016/S0167-4781(97)00198-X

Lee, K., Bae, D. W., Kim, S. H., Han, H. J., Liu, X., Park, H. C., et al. (2010). Comparative proteomic analysis of the short-term responses of rice roots and leaves to cadmium. J. Plant Physiol. 167, 161-168. doi: 10.1016/j.jplph.2009.09.006

Lee, S. H., Ahsan, N., Lee, K. W., Kim, D. H., Lee, D. G., Kwak, S. S., et al. (2007). Simultaneous overexpression of both CuZn superoxide dismutase and ascorbate peroxidase in transgenic tall fescue plants confers increased tolerance to a wide range of abiotic stresses. J. Plant Physiol. 164, 1626-1638. doi: 10.1016/j.jplph.2007.01.003

Li, L., Huang, X., Borthakur, D., and Ni, H. (2012). Photosynthetic activity and antioxidative response of seagrass Thalassia hemprichii to trace metal stress. Acta Oceanol. Sin. 31, 98-108. doi: 10.1007/s13131-012-0210-3

Li, P., Chen, L., Zhou, Y., Xia, X., Shi, K., Chen, Z., et al. (2013). Brassinosteroidsinduced systemic stress tolerance was associated with increased transcripts of several defence-related genes in the phloem in Cucumis sativus. PLoS ONE 8:e66582. doi: 10.1371/journal.pone.0066582

Li, W. X., Chen, T. B., Huang, Z. C., Lei, M., and Liao, X. Y. (2006). Effect of arsenic on chloroplast ultrastructure and calcium distribution in arsenic hyperaccumulator Pteris vittata L. Chemosphere 62, 803-809. doi: 10.1016/j.chemosphere.2005.04.055

Li, Y., Dhankher, O. P., Carreira, L., Lee, D., Chen, A., Schroeder, J. I., et al. (2004). Overexpression of phytochelatin synthase in Arabidopsis leads to enhanced arsenic tolerance and cadmium hypersensitivity. Plant Cell Physiol. 45, 1787-1797. doi: 10.1093/pcp/pch202

Liang, W. H., Li, L., Zhang, F., Liu, Y. X., Li, M. M., Shi, H. H., et al. (2013). Effects of abiotic stress, light, phytochromes and phytohormones on the expression of OsAQP, a rice aquaporin gene. Plant Growth Regul. 69, 21-27. doi: $10.1007 /$ s10725-012-9743-x

Liang Zhu, Y., Pilon-Smits, E. A. H., Jouanin, L., and Terry, N. (1999). Overexpression of glutathione synthetase in Indian mustard enhances cadmium cccumulation and tolerance. Plant Physiol. 119, 173-180.

Lidon, F. C., and Henriques, F. S. (1991). Limiting step on photosynthesis of rice plants treated with varying copper levels. J. Plant Physiol. 138, 115-118.

Lin, C. C., and Kao, C. H. (2000). Effect of $\mathrm{NaCl}$ stress on $\mathrm{H} 2 \mathrm{O} 2$ metabolism in rice leaves. J. Plant Growth Regul. 30, 151-155. doi: 10.1023/A:10063451 26589

Lin, T., Zhu, X., Zhang, F., and Wan, X. (2011). The detoxification effect of cadmium stress in Populus yunnanensis. Res. J. Bot. 4, 13-19. doi: 10.3923/brj.2011.13.19

Lin, Y. F., Liang, H. M., Yang, S. Y., Boch, A., Clemens, S., Chen, C. C., et al. (2009). Arabidopsis IRT3 is a zinc-regulated and plasma membrane localized zinc/iron transporter. New Phytol. 182, 392-404. doi: 10.1111/j.1469-8137.2009.02766.x

Lingua, G., Bona, E., Todeschini, V., Cattaneo, C., Marsano, F., Berta, G., et al. (2012). Effects of heavy metal and arbuscular mycorrhiza on the leaf proteome of a selected Poplar clone: A time course analysis. PLoS ONE 7:e38662. doi: 10.1371/journal.pone.0038662

Liu, D., Jiang, W., and Li, M. (1992). Effects of trivalent and hexavalent chromium on root growth and cell division of Allium cepa. Hereditas 117, 23-29. doi: 10.1111/j.1601-5223.1992.tb00003.x

Liu, G. Y., Zhang, Y. X., and Chai, T. Y. (2011). Phytochelatin synthase of Thlaspi caerulescens enhanced tolerance and accumulation of heavy metal when expressed in yeast and tobacco. Plant Cell Rep. 30, 1067-1076. doi: 10.1007/s00299-011-1013-2

Liu, X., Wu, H., Ji, C., Wei, L., Zhao, J., and Yu, J. (2013). An integrated proteomic and metabolomic study on the chronic effects of mercury in Suaeda salsa under an environmentally relevant salinity. PLoS ONE 8:e64041. doi: 10.1371/journal.pone.0064041

Loeffler, S., Hochberger, A., Grill, E., Winnacker, E.-L., and Zenk, M.-H. (1989). Termination of the phytochelatin synthase reaction through sequestration of heavy metals by the reaction product. FEBS Lett. 258, 42-46. doi: 10.1016/00145793(89)81611-4

Long, T. A., Tsukagoshi, H., Busch, W., Lahner, B., Salt, D. E., and Benfey, P. N. (2010). The bHLH transcription factor POPEYE regulates response to iron deficiency in Arabidopsis roots. Plant Cell 22, 2219-2236. doi: 10.1105/tpc.110.074096

López-Millán, A. F., Ellis, D. R., and Grusak, M. A. (2004). Identification and characterization of several new members of the ZIP family of metal ion transporters in Medicagotruncatula. Plant Mol. Biol. 54, 583-596. doi: 10.1023/B:PLAN.0000038271.96019.aa

Lu, Y. P., Li, Z. S., and Rea, P. A. (1997). AtMRP1 gene of Arabidopsis encodes a glutathione $\mathrm{S}$-conjugate pump: isolation and functional definition of a plant ATP-binding cassette transporter gene. Proc. Natl. Acad. Sci. U.S.A. 94, 8243-8248. doi: 10.1073/pnas.94.15.8243

Lu, Y. P., Li, Z. S., Drozdowicz, Y. M., Hortensteiner, S., Martinoia, E., and Rea, P. A. (1998). AtMRP2, an Arabidopsis ATP binding cassette transporter able to transport glutathione S-conjugates and chlorophyll catabolites: functional comparisons with AtMRP1. Plant Cell 10, 267-282.

Lushchak, V. I., and Semchuk, N. M. (2012). Tocopherol biosynthesis: chemistry, regulation and effects of environmental factors. Acta Physiol. Plant. 34, 16071628. doi: 10.1007/s11738-012-0988-9

Ma, J. F., Yamaji, N., Mitani, N., Xu, X. Y., Su, Y. H., McGrath, S. P., et al. (2008). Transporters of arsenite in rice and their role in arsenic accumulation in rice grain. Proc. Natl. Acad. Sci. U.S.A. 105, 9931-9935. doi: 10.1073/pnas.0802361105

Ma, L. Q., Komar, K. M., Tu, C., Zhang, W., Cai, Y., and Kennelly, E. D. (2001). A fern that hyperaccumulates arsenic. Nature 409, 579. doi: 10.1038/35054664

Maleva, M. G., Nekrasova, G. F., Borisova, G. G., Chukina, N. V., and Ushakova, O. S. (2012). Effect of heavy metal on photosynthetic apparatus and antioxidant status of elodea. Russ. J. Plant Physiol. 59, 190-197. doi: 10.1134/S1021443712020069

Manavalan, L. P., Guttikonda, S. K., Tran, L.-S. P., and Nguyen, H. T. (2009). Physiological and molecular approaches to improve drought resistance in soybean. Plant Cell Physiol. 50, 1260-1276. doi: 10.1093/pcp/pcp082

Marschner, H. (1995). Mineral Nutrition of Higher Plants. Boston, MA: Academic Press.

Mäser, P., Thomine, S., Schroeder, J. I., Ward, J. M., Hirschi, K., Sze, H., et al. (2001). Phylogenetic relationships within cation transporter families of Arabidopsis. Plant Physiol. 126, 1646-1667. doi: 10.1104/pp.126.4.1646

Masood, A., Iqbal, N., and Khan, N. A. (2012). Role of ethylene in alleviation of cadmium-induced photosynthetic capacity inhibition by sulfur in mustard. Plant Cell Environ. 35, 524-533. doi: 10.1111/j.1365-3040.2011.02432.x

Mathys, W. (1977). The role of malate, oxalate, and mustard oil glucosides in the evolution of zinc resistance in herbage plants. Physiol. Plant. 40, 130-136. doi: 10.1111/j.1399-3054.1977.tb01509.x

Matsuoka, M. (2003). Gibberellin signaling: how do plant cells respond to GA signals? J. Plant Growth Regul. 22, 123-125. doi: 10.1007/s00344-003-0039-2

Matusik, J., Bajda, T., and Manecki, M. (2008). Immobilization of aqueous cadmium by addition of phosphates. J. Hazard. Mater. 152, 1332-1339. doi: 10.1016/j.jhazmat.2007.08.010

McLaughlin, M. J., Parker, D. R., and Clark, J. M. (1999). Metal and micronutrients-food safety issues. Field Crops Res. 60, 143-163. doi: 10.1016/S0378-4290(98)00137-3

Meharg, A. A., and Hartley-Whitaker, J. (2002). Arsenic uptake and metabolism in arsenic resistant and non resistant plant species. New Phytol. 154, 29-43. doi: 10.1046/j.1469-8137.2002.00363.x

Meister, A., and Anderson, M. E. (1983). Glutathione. Annu. Rev. Biochem. 52, 711-760. doi: 10.1146/annurev.bi.52.070183.003431

Meng, H., Hua, S., Shamsi, I. H., Jilani, G., Li, Y., and Jiang, L. (2009). Cadmiuminduced stress on the seed germination and seedling growth of Brassica napus L., and its alleviation through exogenous plant growth regulators. Plant Growth Regul. 58, 47-59. doi: 10.1007/s10725-008-9351-y

Menguer, P. K., Farthing, E., Peaston, K. A., Ricachenevsky, F. K., Fett, J. P., and Williams, L. E. (2013). Functional analysis of the rice vacuolar zinc transporter OsMTP1. J. Exp. Bot. 64, 2871-2883. doi: 10.1093/jxb/ert136

Métraux, J. P. (2002). Recent breakthroughs in the study of salicylic acid biosynthesis. Trends Plant. Sci. 7, 332-334. doi: 10.1016/S1360-1385(02) 02313-0 
Metwally, A., Finkemeier, I., Georgi, M., and Dietz, K. J. (2003). Salicylic acid alleviates the cadmium toxicity in barley seedlings. Plant Physiol. 132, 272-281. doi: $10.1104 /$ pp.102.018457

Miller, G., Shulaev, V., and Mittler, R. (2008). Reactive oxygen signaling and abiotic stress. Physiol. Plant 133, 481-489. doi: 10.1111/j.1399-3054.2008. 01090.x

Miller, G., Suzuki, N., Ciftci-Yilmaz, S., and Mittler, R. (2010). Reactive oxygen species homeostasis and signaling during drought and salinity stresses. Plant Cell Environ. 33, 453-467. doi: 10.1111/j.1365-3040.2009.02041.x

Mills, R. F., Francini, A., da Rocha, P. S. C. F., Baccarini, P. J., Aylett, M., Krijger, G. C., et al. (2005). The plant P1B-type ATPase AtHMA4 transports Zn and Cd and plays a role in detoxification of transition metals supplied at elevated levels. FEBS Lett. 579, 783-791. doi: 10.1016/j.febslet.2004.12.040

Milner, M. J., and Kochian, L. V. (2008). Investigating heavy-metal hyperaccumulation using Thlaspi caerulescens as a model system. Ann. Bot. 102, 3-13. doi: 10.1093/aob/mcn063

Milner, M. J., Seamon, J., Craft, E., and Kochian, L. V. (2013). Transport properties of members of the ZIP family in plants and their role in $\mathrm{Zn}$ and $\mathrm{Mn}$ homeostasis. J. Exp. Bot. 64, 369-381. doi: 10.1093/jxb/ers315

Miransari, M. (2011). Hyperaccumulators, arbuscular mycorrhizal fungi and stress of heavy metal. Biotechnol. Adv. 29, 645-653. doi: 10.1016/j.biotechadv.2011.04.006

Mishra, S., Tripathi, R. D., Srivastava, S., Dwivedi, S., Trivedi, P. K., Dhankher, O. P., et al. (2009a). Thiol metabolism play significant role during Cd detoxification by Ceratophyllum demersum L. Biores. Tech. 100, 2155-2161. doi: 10.1016/j.biortech.2008.10.041

Mishra, Y., Chaurasia, N., and Rai, L. C. (2009b). AhpC (alkyl hydroperoxide reductase) from Anabaena sp. PCC 7120 protects Escherichia coli from multiple abiotic stresses. Biochem. Biophys. Res. Commun. 381, 606-611. doi: 10.1016/j.bbrc.2009.02.100

Mittler, R. (2002). Oxidative stress, antioxidants and stress tolerance. Trends Plant Sci. 7, 405-410. doi: 10.1016/S1360-1385(02)02312-9

Mittler, R., Vanderauwera, S., Gollery, M., and Van Breusegem, F. (2004). Reactive oxygen gene network of plants. Trends Plant Sci. 9, 490-498. doi: 10.1016/j.tplants.2004.08.009

Mizuno, T., Usui, K., Horie, K., Nosaka, S., Mizuno, N., and Obata, H. (2005). Cloning of three ZIP/Nramp transporter genes from a Ni hyperaccumulator plant Thlaspi japonicum and their $\mathrm{Ni}^{2+}$-transport abilities. Plant Physiol. Biochem. 43, 793-801. doi: 10.1016/j.plaphy.2005.07.006

Møller, I. M., Jensen, P. E., and Hansson, A. (2007). Oxidative modifications to cellular components in plants. Annu. Rev. Plant Biol. 58, 459-481. doi: 10.1146/annurev.arplant.58.032806.103946

Monnet, F., Vaillant, N., Vernay, P., Coudret, A., Sallanon, H., and Hitmi, A. (2001). Relationship between PSII activity, CO2 fixation, and $\mathrm{Zn}, \mathrm{Mn}$ and $\mathrm{Mg}$ contents of Lolium perenne under zinc stress. J. Plant Physiol. 158, 1137-1144. doi: 10.1078/S0176-1617(04)70140-6

Montanini, B., Blaudez, D., Jeandroz, S., Sanders, D., and Chalot, M. (2007). Phylogenetic and functional analysis of the Cation Diffusion Facilitator (CDF) family. Improved signature and prediction of substrate specificity. $B M C$ Genomics 8:107. doi: 10.1186/1471-2164-8-107

Morel, M., Crouzet, J., Gravot, A., Auroy, P., Leonhardt, N., Vavasseur, A., et al. (2009). AtHMA3, a P1B-ATPase allowing $\mathrm{Cd} / \mathrm{Zn} / \mathrm{Co} / \mathrm{Pb}$ vacuolar storage in Arabidopsis. Plant Physiol. 149, 894-904. doi: 10.1104/pp.108.130294

Morita, S., Tasaka, M., Fujisawa, H., Ushimaru, T., and Tsuji, H. (1994). A cDNA clone encoding a rice catalase isozyme. Plant Physiol. 105, 1015-1016. doi: 10.1104/pp.105.3.1015

Mukhopadhyay, A., Vij, S., and Tyagi, A. K. (2004). Overexpression of a zincfinger protein gene from rice confers tolerance to cold, dehydration, and salt stress in transgenic tobacco. Proc. Natl. Acad. Sci. U.S.A. 101, 6309-6314. doi: 10.1073/pnas.0401572101

Munne-Bosch, S. (2005). The role of a9-tocopherol in plant stress tolerance. J. Plant Physiol. 162, 743-748. doi: 10.1016/j.jplph.2005.04.022

Murphy, A., and Taiz, L. (1995). Comparison of metallothionein gene expression and nonprotein thiols in ten Arabidopsis ecotypes. Plant Physiol. 109, 945-954. doi: 10.1104/pp.109.3.945

Muthuchelian, K., Bertamini, M., and Nedunchezhian, N. (2001). Triacontanol can protect Erythrina variegata from cadmium toxicity. J. Plant Physiol. 158, 1487-1490. doi: 10.1078/0176-1617-00627
Nada, E., Ferjani, B. A., Ali, R., Imed, B. R. B. M., and Makki, B. (2007) Cadmium-induced growth inhibition and alteration of biochemical parameters in almond seedlings grown in solution culture. Acta Physil. Plant. 29, 57-62. doi: 10.1007/s11738-006-0009-y

Nagajyoti, P. C., Lee, K. D., and Sreekanth, T. V. M. (2010). Heavy metal, occurrence and toxicity for plants: a review. Environ. Chem. Lett. 8, 199-216. doi: 10.1007/s10311-010-0297-8

Naika, M., Shameer, K., Mathew, O. K., Gowda, R., and Sowdhamini, R. (2013). STIFDB2: an updated version of plant stress-responsive transcription factor database with additional stress signals, stress-responsive transcription factor binding sites and stress-responsive genes in Arabidopsis and rice. Plant Cell Physiol. 54:e8. doi: 10.1093/pcp/pcs185

Nakano, T., Suzuki, K., Fujimura, T., and Shinshi, H. (2006). Genomewide analysis of the ERF gene family in Arabidopsis and rice. Plant Physiol. 140, 411-432. doi: 10.1104/pp.105.073783

Nakashima, K., and Yamaguchi-Shinozaki, K. (2006). Regulons involved in osmotic stress-responsive and cold stress-responsive gene expression in plants. Physiol. Plant. 126, 62-71. doi: 10.1111/j.1399-3054.2005.00592.x

Nakashima, K., Ito, Y., and Yamaguchi-Shinozaki, K. (2009). Transcriptional regulatory networks in response to abiotic stresses in Arabidopsis and grasses. Plant Physiol. 149, 88-95. doi: 10.1104/pp.108.129791

Nan, Z., Li, J., Zhang, J., and Cheng, G. (2002). Cadmium and zinc interactions and their transfer in soil-crop system under actual field conditions. Sci. Total Environ. 285, 187-195. doi: 10.1016/S0048-9697(01)00919-6

NandaKumar, P. B. A., Dushenkov, V., Motto, H., and Raskin, I. (1995). Phytoextraction: the use of plants to remove heavy metal from soils. Environ. Sci. Technol. 29, 1232-1238. doi: 10.1021/es00005a014

Neill, S., Desikan, R., and Hancock, J. (2002). Hydrogen peroxide signaling. Curr. Opin. Plant Biol. 5, 388-395. doi: 10.1016/S1369-5266(02)00282-0

Nies, D. H., and Silver, S. (1995). Ion efflux systems involved in bacterial metal resistances. J. Ind. Microbiol. 14, 186-199. doi: 10.1007/BF01569902

Opdenakker, K., Remans, T., Keunen, E., Vangronsveld, J., and Cuypers, A. (2012). Exposure of Arabidopsis thaliana to $\mathrm{Cd}$ or $\mathrm{Cu}$ excess leads to oxidative stress mediated alterations in MAPKinase transcript levels. Environ. Exp. Bot. 83, 53-61. doi: 10.1016/j.envexpbot.2012.04.003

Ortiz, D. F., Kreppel, L., Speiser, D. M., Scheel, G., McDonald, G., and Ow, D. W. (1992). Heavy metal tolerance in the fission yeast requires an ATP-binding cassette-type vacuolar membrane transporter. EMBO J. 11, 3491-3499.

Ortiz, D. F., Ruscitti, T., McCue, K. F., and Ow, D. W. (1995). Transport of metalbinding peptides by HMT1, a fission Yeast ABC-type vacuolar membrane protein. J. Biol. Chem. 270, 4721-4728. doi: 10.1074/jbc.270.9.4721

Pal'ove-Balang, P., Kisová, A., Pavlovkin, J., and Mistrík, I. (2006). Effect of manganese on cadmium toxicity in maize seedlings. Plant Soil Environ. 52, 143-149. Available online at: http://www.agriculturejournals.cz/publicFiles/ 50533.pdf

Panda, S. K., Baluska, F., and Matsumoto, H. (2009). Aluminum stress signaling in plants. Plant Signal. Behav. 4, 592-597. doi: 10.4161/psb.4.7.8903

Pankovic, D., Plesnicar, M., Arsenijeevic-Maksimovic, I., Petrovic, N., Sakac, Z., and Kastori, R. (2000). Effects of nitrogen nutrition on photosynthesis in Cdtreated sunflower plants. Ann. Bot. 86, 841-847. doi: 10.1006/anbo.2000.1250

Papoyan, A., and Kochian, L. V. (2004). Identification of Thlaspi caerulescens genes that may be involved in heavy metal hyperaccumulationand tolerance. Characterization of a novel heavy metal transporting ATPase. Plant Physiol. 136, 3814-3823. doi: 10.1104/pp.104.044503

Pawlak-Sprada, S., Arasimowicz-Jelonek, M., Podgórska, M., and Deckert, J. (2011). Activation of phenylopropanoid pathway in legume plants exposed to heavy metals. Part I. Effects of cadmium and lead on phenylalanine ammonialyase gene expression, enzyme activity and lignin content. Acta. Biochim. Pol. $58,211-216$.

Peiter, E., Montanini, B., Gobert, A., Pedas, P., Husted, S., Maathuis, F. J. M., et al. (2007). A secretory pathway-localized cation diffussion facilitator confers plant manganese tolerance. Proc. Natl. Acad. Sci. U.S.A. 104, 8532-8537. doi: 10.1073/pnas.0609507104

Peleg, Z., and Blumwald, E. (2011). Hormone balance and abiotic stress tolerance in crop plants. Curr. Opin. Plant Biol. 14, 290-295. doi: 10.1016/j.pbi.2011.02.001

Pena, L. B., Barcia, R. A., Azpilicueta, C. E., Méndez, A. A., and Gallego, S. M. (2012). Oxidative post translational modifications of proteins related to cell 
cycle are involved in cadmium toxicity in wheat seedlings. Plant Sci. 196, 1-7. doi: $10.1016 /$ j.plantsci.2012.07.008

Pence, N. S., Larsen, P. B., Ebbs, S. D., Lasat, M. M., Letham, D. L. D., Garvin, D. F., et al. (2000). The molecular basis for heavy metal hyperaccumulation in Thlaspi caerulescens. Proc. Natl. Acad. Sci. U.S.A. 97, 4956-4960. doi: 10.1073/pnas.97.9.4956

Peng, H. Y., Yang, X. E., and Jiang, L. Y. (2005). Copper phytoavailability and uptake by Elsholtzi asplendens from contaminated soil as affected by soil amendments. J. Environ. Sci. Health 40, 839-856. doi: 10.1081/ESE-200048283

Petö, A., Lehotai, N., Lozano-Juste, J., León, J., Tari, I., Erdei, L., et al. (2011). Involvement of nitric oxide and auxin in signal transduction of copper-induced morphological responses in Arabidopsis seedlings. Ann. Bot. 108, 449-457. doi: $10.1093 / \mathrm{aob} / \mathrm{mcr} 176$

Pilon-Smits, E. A. H., Hwang, S., Lytle, C. M., Zhu, Y., Tai, J. C., Bravo, R. C., et al. (1999). Overexpression of ATP sulfurylase in indian mustard leads to increased selenate uptake, reduction, and tolerance. Plant Physiol. 119, 1123-1132. doi: 10.1104/pp.119.1.123

Pilon-Smits, E. A. H., Zhu, Y. L., Sears, T., and Terry, N. (2000). Overexpression of glutathione reductase in Brassica juncea: effects on cadmium accumulation and tolerance. Physiol. Plant. 110, 455-460. doi: 10.1111/j.1399-3054.2000.1100405.x

Podar, D., Scherer, J., Noordally, Z., Herzyk, P., Nies, D., and Sanders, D. (2012). Metal selectivity determinants in a family of transition metal transporters. J. Biol. Chem. 287, 3185-3196. doi: 10.1074/jbc.m111.305649

Pomponi, M., Censi, V., Di Girolamo, V., De Paolis, A., di Toppi, L. S., Aromolo, R., et al. (2006). Overexpression of Arabidopsis phytochelatin synthase in tobacco plants enhances $\mathrm{Cd}(2+)$ tolerance and accumulation but not translocation to the shoot. Planta 223, 180-190. doi: 10.1007/s00425-0050073-3

Popova, L. P., Maslenkova, L. T., Yordanova, R. Y., Ivanova, A. P., Krantev, A. P., Szalai, G., et al. (2009). Exogenous treatment with salicylic acid attenuates cadmium toxicity in pea seedlings. Plant Physiol. Biochem. 47, 224-231. doi: 10.1016/j.plaphy.2008.11.007

Prasad, A. S. (2012). Discovery of human zinc deficiency: 50 years later. J. Trace Elem. Med. Biol. 26, 66-69. doi: 10.1016/j.jtemb.2012.04.004

Prasad, M. N. V., Freitas, H., Fraenzle, S., Wuenschmann, S., and Markert, B. (2010). Knowledge explosion in phytotechnologies for environmental solutions. Environ. Pollut. 158, 18-23. doi: 10.1016/j.envpol.2009.07.038

Qiu, Z. Z., Guan, Z. Y., and Long, C. Y. (2005). Effect of zinc on cadmium uptake by spring wheat (Triticum aestivum L.): long time hydroponic study and short time 109Cd tracing study. J. Zhejiang Univ. Sci. 6, 643-648. doi: 10.1007/BF02856167

Qureshi, M. I., D’Amici, G. M., Fagioni, M., Rinalducci, S., and Zolla, L. (2010). Iron stabilizes thylakoid protein-pigment complexes in indian mustard during Cd-phytoremediation as revealed by BN-SDS-PAGE and ESI-MS/MS. J. Plant Physiol. 167, 761-770. doi: 10.1016/j.jplph.2010.01.017

Rai, V. K. (2002). Role of amino acids in plant responses to stress. Biol. Plant. 45, 481-487. doi: 10.1023/A:1022308229759

Ramos, J., Clemente, M. R., Naya, L., Loscos, J., Perez-Rontome, C., Sato, S., et al. (2007). Phytochelatin synthases of the model legume Lotus japonicus. A small multigene family with different responses to cadmium and alternatively spiced variants. Plant Physiol. 143, 110-118. doi: 10.1104/pp.106.090894

Rascio, N. (1997). Metal accumulation by some plants growing on zinc-mine deposits. Oikos 29, 250-253. doi: 10.2307/3543610

Rauser, W. E. (1995). Phytochelatins and related peptides. Structure, biosynthesis, and function. Plant Physiol. 109, 1141-1149. doi: 10.1104/pp.109.4.1141

Rauser, W. E. (1999). Structure and function of metal chelators produced by plants. The case for organic acids, amino acids, phytin and metallothioneins. Cell Biochem. Biophys. 31, 19-48. doi: 10.1007/BF02738153

Ravet, K., Touraine, B., Boucherez, J., Briat, J. F., Gaymard, F., and Cellier, F. (2009). Ferritins control interaction between iron homeostasis and oxidative stress in Arabidopsis. Plant J. 57, 400-412. doi: 10.1111/j.1365313X.2008.03698.x

Reeves, R. D. (2006). "Hyperaccumulation of trace elements by plants," in Phytoremediation of Metal-Contaminated Soils, NATO Science Series: IV: Earth and Environmental Sciences, eds J. L. Morel, G. Echevarria, and N. Goncharova (New York, NY: Springer), 25-52.

Ricachenevsky, F. K., Menguer, P. K., Sperotto, R. A., Williams, L. E., and Fett, J. P. (2013). Roles of plant metal tolerance proteins (MTP) in metal storage and potential use in biofortification strategies. Front. Plant Sci 4:144. doi: 10.3389/fpls.2013.00144

Ritter, A., Ubertini, M., Romac, S., Gaillard, F., Delage, L., Mann, A., et al. (2010). Copper stress proteomics highlights local adaptation of two strains of the model brown alga Ectocarpus siliculosus. Proteomics 10, 2074-2088. doi: 10.1002/pmic.200900004

Rivas-San Vicente, M., and Plasencia, J. (2011). Salicylic acid beyond defence: its role in plant growth and development. J. Exp. Bot. 62, 3321-3338. doi: $10.1093 / \mathrm{jxb} / \mathrm{err} 031$

Rodríguez-Serrano, M., Romero-Puertas, M. C., Pazmiňo, D. M., Testillano, P. S., Risueňo, M. C., Del Río, L. A., et al. (2009). Cellular response of pea plants to cadmium toxicity: cross talk between reactive oxygen species, nitric oxide, and calcium. Plant Physiol. 150, 229-243. doi: 10.1104/pp.108.131524

Roth, U., von Roepenack-Lahaye, E., and Clemens, S. (2006). Proteome changes in Arabidopsis thaliana roots upon exposure to $\mathrm{Cd}^{2+}$. J. Exp. Bot. 57, 4003-4013. doi: $10.1093 / \mathrm{jxb} / \mathrm{erl} 170$

Ruiz, O. N., Alvarez, D., Torres, C., Roman, L., and Daniell, H. (2011). Metallothionein expression in chloroplasts enhances mercury accumulation and phytoremediation capability. Plant Biotechnol. J. 9, 609-617. doi: $10.1111 / j .1467-7652.2011 .00616 . x$

Safarzadeh, S., Ronaghi, A., and Karimian, N. (2013). Effect of cadmium toxicity on micronutrient concentration, uptake and partitioning in seven rice cultivars. Arch. Agron. Soil Sci. 59, 231-245. doi: 10.1080/03650340.2011.622752

Saito, A., Saito, M., Ichikawa, Y., Yoshiba, M., Tadano, T., Miwa, E., et al. (2010). Difference in the distribution and speciation of cellular nickel between nickeltolerant and non-tolerant Nicotiana tabacum L. cv. BY-2 cells. Plant Cell Environ. 33, 174-187. doi: 10.1111/j.1365-3040.2009.02068.x

Salt, D. E., and Rauser, W. E. (1995). MgATP-dependent transport of phytochelatins across the tonoplast of oat roots. Plant Physiol. 107, 1293-1301.

Salt, D. E., Baxter, I., and Lahner, B. (2008). Ionomics and the study of the plant ionome. Annu. Rev. Plant Biol. 59, 709-733. doi: 10.1146/annurev.arplant.59.032607.092942

Salt, D. E., Prince, R. C., Baker, A. J. M., Raskin, I., and Pickering, I. J. (1999). Zinc ligands in the metal accumulator Thlaspi caerulescensas determined using X-ray absorption spectroscopy. Environ. Sci. Technol. 33, 713-717. doi: 10.1021/es980825x

Sánchez-Bermejo, E., Castrillo, G., del Llano, B., Navarro, C., Zarco-Fernández, S., Martinez- Herrera, D. J., et al. (2014). Natural variation in arsenate tolerance identifies an arsenate reductase in Arabidopsis thaliana. Nat. Commun. 5:4617. doi: $10.1038 /$ ncomms5617

Sánchez-Pardo, B., Fernández-Pascual, M., and Zornoza, P. (2012). Copper microlocalisation, ultrastructural alterations and antioxidant responses in the nodules of white lupin and soybeanplants grown under conditions of copper excess. Environ. Exp. Bot. 84, 52-60. doi: 10.1016/j.envexpbot.2012.04.017

Sanita di Toppi, L., and Gabbrielli, R. (1999). Response to cadmium in higher plants. Environ. Exp. Bot. 41, 105-130. doi: 10.1016/S0098-8472(98)00058-6

Sano, T., Yoshihara, T., Handa, K., Sato, M. H., Nagata, T., and Hasezawa, S. (2012). "Metal ion homeostasis mediated by NRAMP transporters in plant cells-focused on increased resistance to iron and cadmium ion," in Crosstalk and Integration of Membrane Trafficking Pathways, ed R. Weigert (InTech), 213-228. Available online at: http://www.intechopen.com/books/crosstalkand-integration-of-membrane-trafficking-pathways/metal-ion-homeostasismediated-by-nramp-transporters-in-plant-cells-focused-on-increasedresistance-

Sarret, G., Saumitou-Laprade, P., Bert, V., Proux, O., Hazemann, J. L., Traverse, A., et al. (2002). Forms of zinc accumulated in the hyperaccumulator Arabidopsis halleri. Plant Physiol. 130, 1815-1826. doi: 10.1104/pp.007799

Sarwar, N., Saifullah., Malhi, S. S., Zia, M. H., Naeem, A., Bibia, S., and Farida, G. (2010). Role of mineral nutrition in minimizing cadmium accumulation by plants. J. Sci. Food Agric. 90, 925-937. doi: 10.1002/jsfa.3916

Sasaki, A., Yamaji, N., Yokosho, K., and Ma, J. F. (2012). Nramp5 is a major transporter responsible for manganese and cadmium uptake in rice. Plant Cell. 24, 2155-2167. doi: 10.1105/tpc.112.096925

Schafer, C., Simper, H., and Hofmann, B. (1992). Glucose feeding results in coordinated changes of chlorophyll content, ribulose-1,5-biphosphate carboxylase-oxygenase activity and photosynthetic potential photoautotrophic suspension cultured cells of Chenopodium ruburum. Plant Cell Environ. 15, 343-350. 
Schaaf, G., Honsbein, A., Meda, A. R., Kirchner, S., Wipf, D., and von Wirén, N. (2006). AtIREG2 encodes a tonoplast transport protein involved in irondependent nickel detoxification in Arabidopsis thaliana roots. J. Biol. Chem. 281, 25532-25540. doi: 10.1074/jbc.M601062200

Scholz, G., Schlesier, G., and Seifert, K. (1985). Effect of nicotianamine on iron uptake by the tomato mutant 'chloronerva'. Physiol. Plant. 63, 99-104. doi: 10.1111/j.1399-3054.1985.tb02825.x

Schützendübel, A., and Polle, A. (2002). Plant responses to abiotic stresses: heavy metal-induced oxidative stress and protection by mycorrhization. J. Exp. Bot. 53, 1351-1365. doi: 10.1093/jexbot/53.372.1351

Schwarz, K., and Foltz, C. M. (1957). Selenium as an integral part of factor 3 against dietary necrotic liver degeneration. J. Am. Chem. Soc. 70, 3292-3293. doi: 10.1021/ja01569a087

Semane, B., Dupae, J., Cuypers, A., Noben, J. P., Tuomainen, M., Tervahauta, A., et al. (2010). Leaf proteome responses of Arabidopsis thaliana exposed to mild cadmium stress. J. Plant Physiol. 167, 247-254. doi: 10.1016/j.jplph.2009.09.015

Shahid, M., Pinelli, E., and Dumat, C. (2012). Review of Pb availability and toxicity to plants in relation with metal speciation; role of synthetic and natural organic ligands. J. Hazard. Mater. 219-220, 1-12. doi: 10.1016/j.jhazmat.2012.01.060

Shahzad, Z., Gosti, F., Frerot, H., Lacombe, E., Roosens, N., Saumitou- Laprade, P., et al. (2010). The five AhMTP1 zinc transporters undergo different evolutionary fates towards adaptive evolution to zinc tolerance in Arabidopsis halleri. PLoS Genet. 6:e1000911. doi: 10.1371/journal.pgen.1000911

Shameer, K., Ambika, S., Varghese, S. M., Karaba, N., Udayakumar, M., and Sowdhamini, R. (2009). STIFDB-Arabidopsis stress-responsive transcription factor DataBase. Int. J. Plant Genomics 2009:583429. doi: 10.1155/2009/583429

Shanker, K., Mishra, S., Srivastava, S., Srivastava, R., Daas, S., Prakash, S., et al. (1996). Effect of selenite and selenate on plant uptake and translocation of mercury by tomato (Lycopersicum esculentum). Plant Soil 183, 233-238. doi: 10.1007/BF00011438

Shanmugam, V., Lo, J. C., Wu, C. L., Wang, S. L., Lai, C. C., Connolly, E. L., et al. (2011). Differential expression and regulation of iron regulated metal transporters in Arabidopsis halleri and Arabidopsis thaliana-the role in zinc tolerance. New Phytol. 190, 125-137. doi: 10.1111/j.1469-8137.2010.03606.x

Sharaf, A. E. M. M., Farghal, I. I., and Sofy, M. R. (2009). Role of gibberellic acid in abolishing the detrimental effects of $\mathrm{Cd}$ and $\mathrm{Pb}$ on broad bean and Lupin plants. Res. J. Agric. Biol. Sci. 5, 668-673. Available online at: https://www.researchgate. net/publication/242631571

Sharma, I., Pati, P. K., and Bhardwaj, R. (2011). Effect of 28-homobrassinolide on antioxidant defence system in Raphanus sativus L. under chromium toxicity. Ecotoxicology 20, 862-874. doi: 10.1007/s10646-011-0650-0

Sharma, P., and Bhardwaj, R. (2007). Effects of 24-epibrassinolide on growth and metal uptake Brassica juncea L. under copper metal stress. Acta Physiol. Plant. 29, 259-263. doi: 10.1007/s11738-007-0032-7

Sharma, P., Bhardwaj, R., Arora, N., Arora, H. K., and Kumar, A. (2008). Effects of 28-homobrassinolide on nickel uptake, protein content and antioxidative defence system in Brassica juncea. Biol. Plant 52, 767-770. doi: 10.1007/s10535008-0149-6

Sharma, S. S., and Dietz, K. J. (2009). The relationship between metal toxicity and cellular redox imbalance. Trends Plant Sci. 14, 43-50. doi: 10.1016/j.tplants.2008.10.007

Sharma, S. S., and Dietz, K. J. (2006). The significance of amino acids and amino acid-derived molecules in plant responses and adaptation to heavy metal stress. J. Exp. Bot. 57, 711-726. doi: 10.1093/jxb/erj073

Sharmin, S. A., Alam, I., Kim, K. H., Kim, Y. G., Kim, P. J., Bahk, J. D., et al. (2012). Chromium-induced physiological and proteomic alterations in roots of Miscanthus sinensis. Plant Sci. 187, 113-126. doi: 10.1016/j.plantsci.2012.02.002

Shen, W., Nada, K., and Tachibana, S. (2000). Involvement of polyamines in the chilling tolerance of cucumber cultivars. Plant Physiol. 124, 431-439. doi: 10.1104/pp.124.1.431

Shi, Q., and Zhu, Z. (2008). Effects of exogenous salicylic acid on manganese toxicity, element contents and antioxidative system in cucumber. Environ. Exp. Bot. 63, 317-326. doi: 10.1016/j.envexpbot.2007.11.003

Shi, X. H., Zhang, C. H., Wang, H., and Zhang, F. S. (2005). Effect of Si on the distribution of Cd in rice seedlings. Plant Soil 272, 53. doi: 10.1007/s11104-0043920-2

Shim, D., Hwang, J. U., Lee, J., Lee, S., Choi, Y., An, G., et al. (2009). Orthologs of the class A4 heat shock transcription factor HsfA4a confer cadmium tolerance in wheat and rice. Plant Cell 21, 4031-4043. doi: 10.1105/tpc.109. 066902

Shin, S. Y., Kim, I. S., Kim, Y. H., Park, H. M., Lee, J. Y., Kang, H. G., et al. (2008). Scavenging reactive oxygen species by rice dehydroascorbate reductase alleviates oxidative stresses in Escherichia coli. Mol. Cells 26, 616-620.

Shiu, S. H., Shih, M. C., and Li, W. H. (2005). Transcription factor families have much higher expansion rates in plants than in animals. Plant Physiol. 139, 18-26. doi: 10.1104/pp.105.065110

Siborova, M. (1988). Cd2 ${ }^{+}$ions affect the quaternary structure of ribulose-1,5bisphosphate carboxylase from barley leaves. Biochem. Physiol. Pflanzen 183, 371-378. doi: 10.1016/S0015-3796(88)80045-3

Siddiqui, M. H., Al-Whaibi, M. H., and Basalah, M. O. (2011). Interactive effect of calcium and gibberellin on nickel tolerance in relation to antioxidant systems in Triticum aestivum L. Protoplasma 248, 503-511. doi: 10.1007/s00709-0100197-6

Silva, S. (2012). Aluminium toxicity targets in plants. J. Bot. 2012:219462. doi: $10.1155 / 2012 / 219462$

Simões, C. C., Melo, J. O., Magalhaes, J. V., and Guimarães, C. T. (2012). Genetic and molecular mechanisms of aluminum tolerance in plants. Genet. Mol. Res. 11, 1949-1957. doi: 10.4238/2012.July.19.14

Singh, K., Foley, R. C., and Oñate-Sánchez, L. (2002). Transcription factors in plant defense and stress responses. Curr. Opin. Plant Biol. 5, 430-436. doi: 10.1016/S1369-5266(02)00289-3

Singh, N., Ma, L. Q., Vu, J. C., and Raj, A. (2009). Effects of arsenic on nitrate metabolism in arsenic hyperaccumulating and non-hyperaccumulating ferns. Environ. Pollut. 157, 2300-2305. doi: 10.1016/j.envpol.2009.03.036

Singh, R. K., Anandhan, S., Singh, S., Patade, V. Y., Ahmed, Z., and Pande, V. (2011a). Metallothionein-like gene from Cicer microphyllumis regulated by multiple abiotic stresses. Protoplasma 248, 839-847. doi: 10.1007/s00709-0100249-y

Singh, V. P., Singh, S., Kumar, J., and Prasad, S. M. (2015). Investigating the roles of ascorbate-glutathione cycle and thiol metabolism in arsenate tolerance in ridged Luffa seedlings. Protoplasma 252, 1217-1229. doi: 10.1007/s00709-0140753-6

Singh, V. P., Srivastava, P. K., and Prasad, S. M. (2012). Differential effect of UV-B radiation on growth, oxidative stress and ascorbate-glutathione cycle in two cyanobacteria under copper toxicity. Plant Physiol. Biochem. 61, 61-70. doi: 10.1016/j.plaphy.2012.09.005

Singh, V. P., Srivatava, P. K., and Prasad, S. M. (2013). Nitric oxide alleviates arsenic-induced toxic effects in ridged Luffa seedlings. Plant. Physiol. Biochem. 71, 155-163. doi: 10.1016/j.plaphy.2013.07.003

Singh, V. P., Tripathi, D. K., Kumar, D., and Chauhan, D. K. (2011b). Influence of exogenous silicon addition on aluminium tolerance in rice seedlings. Biol. Trace Elem. Res. 144, 1260-1274. doi: 10.1007/s12011-0119118-6

Siripornadulsil, S., Traina, S., Verma, D. P. S., and Sayre, R. T. (2002). Molecular mechanisms of proline-mediated tolerance to toxic heavy metal in transgenic microalgae. Plant Cell 14, 2837-2847. doi: 10.1105/tpc.004853

Smith, P., Gregory, P. J., van Vuuren, D., Obersteiner, M., Havlík, P., Rounsevell, M., et al. (2010). Competition for land. Philos. Trans R. Soc. B Biol. Sci. 365, 2941-2957. doi: 10.1098/rstb.2010.0127

Sobkowiak, R., and Deckert, J. (2006). Proteins induced by cadmium in soybean cells. J. Plant Physiol. 163, 1203-1206. doi: 10.1016/j.jplph.2005.08.017

Song, A., Li, Z., Zhang, J., Xue, G., Fan, F., and Liang, Y. (2009). Silicon-enhanced resistance to cadmium toxicity in Brassica chinensis L. is attributed to Si-suppressed cadmium uptake and transport and Sienhanced antioxidant defense capacity. J. Hazard. Mater. 172, 74-83. doi: 10.1016/j.jhazmat.2009.06.143

Song, W.-Y., Yamaki, T., Yamaji, N., Ko, D., Jung, K. H., Fujii-Kashino, M., et al. (2014). A rice ABC transporter, OsABCC1, reduces arsenic accumulation in the grain. PNAS 111, 15699-15704. doi: 10.1073/pnas.1414968111

Sooksa-Nguan, T., Yakubov, B., Kozlovskyy, V. I., Barkume, C. M., Howe, K. J., Thannhauser, T. W., et al. (2009). Drosophila ABC transporter, DmHMT-1, confers tolerance to cadmium. DmHMT-1 and its yeast homolog, SpHMT-1, are not essential for vacuolar phytochelatin sequestration. J. Biol. Chem. 284, 354-362. doi: 10.1074/jbc.M806501200

Srivastava, G., Kumar, S., Dubey, G., Mishra, V., and Prasad, S. M. (2012). Nickel and ultraviolet-B stresses induce differential growth and photosynthetic 
responses in Pisum sativum L. seedlings. Biol. Trace Elem. Res. 149, 86-96. doi: 10.1007/s12011-012-9406-9

Srivastava, S., Srivastava, A. K., Suprasanna, P., and D'Souza, S. F. (2013). Identification and profiling of arsenic stress-induced microRNAs in Brassica juncea. J. Exp. Bot. 64, 303-315. doi: 10.1093/jxb/ers333

Stephan, U. W., and Scholz, G. (1993). Nicotianamine: mediator of transport of iron and heavy metals in the phloem? Physiol. Plant. 88, 522-529.

Street, R. A., Kulkarni, M. G., Stirk, W. A., Southway, C., and Van Staden, J. (2010). Effect of cadmium on growth and micronutrient distribution in wild garlic (Tulbaghia violacea). South Afr. J. Bot. 76, 332-336. doi: 10.1016/j.sajb.2009.12.006

Strobel, N. E., and Kuc, A. (1995). Chemical and biological inducers ofsystemic acquired resistance to pathogens protect cucumber andtobacco from damage caused by paraquat and cupric chloride. Phytopathol 85, 1306-1310. doi: 10.1094/Phyto-85-1306

Sundaramoorthy, P., Chidambaram, A., Ganesh, K. S., Unnikannan, P., and Baskaran, L. (2010). Chromium stress in paddy: (i) nutrient status of paddy under chromium stress; (ii) phytoremediation of chromium by aquatic and terrestrial weeds. C. R. Biol. 333, 597-607. doi: 10.1016/j.crvi.2010.03.002

Suzuki, N. (2005). Alleviation by calcium of cadmium induced root growth inhibition in Arabidopsis seedlings. Plant Biotechnol. 22, 19-25. doi: 10.5511/plantbiotechnology.22.19

Takahashi, H., Kawakatsu, T., Wakasa, Y., Hayashi, S., and Takaiwa, F. (2012). A rice transmembrane bZIP transcription factor, OsbZIP39, regulates the endoplasmic reticulum stress response. Plant Cell Physiol. 53, 144-153. doi: $10.1093 / \mathrm{pcp} / \mathrm{pcr} 157$

Talanova, V. V., Titov, A. F., and Boeva, N. P. (2000). Effect of increasing concentration of lead and cadmium on cucumber seedlings. Biol. Plant. 43, 441-444. doi: 10.1023/A:1026735603890

Talke, I. N., Hanikenne, M., and Krämer, U. (2006). Zinc-dependent global transcriptional control, transcriptional deregulation, and higher gene copy number for genes in metal homeostasis of the hyperaccumulator Arabidopsis halleri. Plant Physiol. 142, 148-167. doi: 10.1104/pp.105.076232

Tamás, L., Mistrík, I., Huttová, J., Halusková, L., Valentovicová, K., and Zelinová, V. (2010). Role of reactive oxygen species-generating enzymes and hydrogen peroxide during cadmium, mercury and osmotic stresses in barley root tip. Planta 231, 221-231. doi: 10.1007/s00425-009-1042-z

Tang, W., Charles, T. M., and Newton, R. J. (2005). Overexpression of the pepper transcription factor CaPF1 in transgenic Virginia pine (Pinus Virginiana Mill.) confers multiple stress tolerance and enhances organ growth. Plant Mol. Biol. 59, 603-617. doi: 10.1007/s11103-005-0451-z

Thomine, S., Lelièvre, F., Debarbieux, E., Schroeder, J. I., and Barbier-Brygoo, H. (2003). AtNRAMP3, a multispecificvacuolar metal transporter involved in plant responses to iron deficiency. Plant J. 34, 685-695. doi: 10.1046/j.1365313X.2003.01760.x

Thomine, S., Wang, R., Ward, J. M., Crawford, N. M., and Schroeder, J. I. (2000). Cadmium and iron transport by members of a plant transporter gene family in Arabidopsis with homology to NRAMP genes. Proc. Nat. Acad. Sci. U.S.A. 97, 4991-4996. doi: 10.1073/pnas.97.9.4991

Thounaojam, T. C., Panda, P., Mazumdar, P., Kumar, D., Sharma, G. D., Sahoo, L., et al. (2012). Excess copper induced oxidative stress and response of antioxidants in rice. Plant Physiol. Biochem. 53, 33-39. doi: 10.1016/j.plaphy.2012.01.006

Tiwari, M., Sharma, D., Dwivedi, S., Singh, M., Tripathi, R. D., and Trivedi, P. K. (2014). Expression in Arabidopsis and cellular localization reveal involvement of rice NRAMP, OsNRAMP1, in arsenic transport and tolerance. Plant Cell Environ. 37, 140-152. doi: 10.1111/pce.12138

Tkalec, M., Štefanić, P. P., Cvjetko, P., Šikić, S., Pavlica, M., and Balen, B. (2014). The effects of cadmium-zinc interactions on biochemical responses in tobacco seedlings and adult plants. PLOS ONE 9:e87582. doi: 10.1371/journal.pone.0087582

Tommey, A. M., Shi, J., Lindsay, W. P., Urwin, P. E., and Robinson, N. J. (1991). Expression of the pea gene PsMTA in E. coli. Metal binding properties of the expressed protein. FEBS Lett. 292, 48-52. doi: 10.1016/0014-5793(91)80831-M

Tran, L. S. P., Nishiyama, R., Yamaguchi-Shinozaki, K., and Shinozaki, K. (2010). Potential utilization of NAC transcription factors to enhance abiotic stress tolerance in plants by biotechnological approach. GM Crops 1, 32-39. doi: 10.4161/gmcr.1.1.10569
Treeby, M., Marschner, H., and Römheld, V. (1989). Mobilization of iron and other micronutrient cations from a calcareous soil by plant-borne, microbial, and synthetic metal chelators. Plant Soil 114, 217-226. doi: 10.1007/BF02220801

Tripathi, D. K., Singh, V. P., Kumar, D., and Chauhan, D. K. (2012). Impact of exogenous silicon addition on chromium uptake, growth, mineral elements, oxidative stress, antioxidant capacity, and leaf and root structures in rice seedlings exposed to hexavalent chromium. Acta Physiol. Plant. 34, 279-289. doi: 10.1007/s11738-011-0826-5

Tseng, M. J., Liu, C. W., and Yiu, J. C. (2007). Enhanced tolerance to sulfur dioxide and salt stress of transgenic Chinese cabbage plants expressing both superoxide dismutase and catalase in chloroplasts. Plant Physiol. Biochem. 45, 822-833. doi: 10.1016/j.plaphy.2007.07.011

Tsukagoshi, H., Busch, W., and Benfey, P. N. (2010). Transcriptional regulation of ROS controls transition from proliferation to differentiation in the root. Cell 143, 606-616. doi: 10.1016/j.cell.2010.10.020

Tu, C., and Ma, L. Q. (2005). Effects of arsenic on concentration and distribution of nutrients in the fronds of the arsenic hyperaccumulator Pteris vittata L. Environ. Pollut. 135, 333-340. doi: 10.1016/j.envpol.2004.03.026

Tuomainen, M. H., Nunan, N., Lehesranta, S. J., Tervahauta, A. I., Hassinen, V. H., Schat, H., et al. (2006). Multivariate analysis of protein profiles of metal hyperaccumulator Thlaspi caerulescens accessions. Proteomics 6, 3696-3706. doi: 10.1002/pmic.200501357

Umezawa, T., Fujita, M., Fujita, Y., Yamaguchi-Shinozaki, K., and Shinozaki, K. (2006). Engineering drought tolerance in plants: discovering and tailoring genes to unlock the future. Curr. Opin. Biotechnol. 17, 113-122. doi: 10.1016/j.copbio.2006.02.002

Valliyodan, B., and Nguyen, H. T. (2006). Understanding regulatory networks and engineering for enhanced drought tolerance in plants. Curr. Opin. Plant Biol. 9, 189-195. doi: 10.1016/j.pbi.2006.01.019

van de Mortel, J. E., Villanueva, L. A., Schat, H., Kwekkeboom, J., Coughlan, S., Moerland, P. D., et al. (2006). Large expression differences in genes for iron and zinc homeostasis, stress response, and lignin biosynthesis distinguish roots of Arabidopsis thaliana and the related metal hyperaccumulator Thlaspi caerulescens. Plant Physiol. 142, 1127-1134. doi: 10.1104/pp.106.082073

van der Zaal, B. J., Neuteboom, L. W., Pinas, J. E., Chardonnens, A. N., Schat, H., Verkleij, J. A., et al. (1999). Overexpression of a novel Arabidopsis gene related to putative zinc-transporter genes from animals can lead to enhanced zinc resistance and accumulation. Plant Physiol. 119, 1047-1055. doi: 10.1104/pp.119.3.1047

Varotto, C., Maiwald, D., Pesaresi, P., Jahns, P., Salamini, F., and Leister, D. (2002). The metal ion transporter IRT1 is necessary for iron homeostasis and efficient photosynthesis in Arabidopsis thaliana. Plant J. 31, 589-599. doi: 10.1046/j.1365-313X.2002.01381.x

Vassilev, A., and Yordanov, I. (1997). Reductive analysis of factors limiting growth of cadmium-treated plants: a review. Bulg. J. Plant Physiol. 23, 114-133.

Vatamaniuk, O. K., Bucher, E. A., Sundaram, M. V., and Rea, P. A. (2005). CeHMT-1, a putative phytochelatin transporter, is required for cadmium tolerance in Caenorhabditis elegans. J. Biol. Chem. 280, 23684-23690. doi: 10.1074/jbc.M503362200

Verbruggen, N., Hermans, C., and Schat, H. (2009). Molecular mechanisms of metal hyperaccumulation in plants. New Phytol. 181, 759-776. doi: 10.1111/j.1469-8137.2008.02748.x

Vert, G., Barberon, M., Zelazny, E., Séguéla, M., Briat, J. F., and Curie, C. (2009). Arabidopsis IRT2 cooperates with the high-affinity iron uptake system to maintain iron homeostasis in root epidermal cells. Planta 229, 1171-1179. doi: 10.1007/s00425-009-0904-8

Vert, G., Grotz, N., Dédaldéchamp, F., Gaymard, F., Guerinot, M. L., Briat, J. F., et al. (2002). IRT1, an Arabidopsis transporter essential for iron uptake from the soil and for plant growth. Plant Cell 14, 1223-1233. doi: 10.1105/tpc.001388

Villiers, F., Jourdain, A., Bastien, O., Leonhardt, N., Fujioka, S., Tichtincky, G., et al. (2012). Evidence for functional interaction between brassinosteroids and cadmium response in Arabidopsis thaliana. J. Exp. Bot. 63, 1185-1200. doi: 10.1093/jxb/err335

Vinocur, B., and Altman, A. (2005). Recent advances in engineering plant tolerance to abiotic stress: achievements and limitations. Curr. Opin. Biotechnol. 16, 123-132. doi: 10.1016/j.copbio.2005.02.001

Vögeli-Lange, R., and Wagner, G. J. (1990). Subcellular localization of cadmium and cadmium-binding peptides in tobacco leaves. Implication of a transport 
function for cadmium-binding peptides. Plant Physiol. 92, 1086-1093. doi: 10.1104/pp.92.4.1086

Vriet, C., Russinova, E., and Reuzeau, C. (2012). Boosting crop yields with plant steroids. Plant Cell 24, 842-857. doi: 10.1105/tpc.111.094912

Walliwalagedara, C., van Keulen, H., Willard, B., and Wei, R. (2012). Differential proteome analysis of Chlamydomonas reinhardtii response to arsenic exposure. Am. J. Plant Sci. 3, 764-772. doi: 10.4236/ajps.2012.36092

Wang, H. Y., Klatte, M., Jakoby, M., Bäumlein, H., Weisshaar, B., and Bauer, P. (2007). Iron deficiency-mediated stress regulation of four subgroup Ib BHLH genes in Arabidopsis thaliana. Planta 226, 897-908. doi: 10.1007/s00425-0070535-x

Wang, H., Zhao, S. C., Liu, R. L., Zhou, W., and Jin, J. Y. (2009). Changes of photosynthetic activities of maize (Zea mays L.) seedlings in response to cadmium stress. Photosynthetica 47, 277-283. doi: 10.1007/s11099-009-0043-2

Wang, R., Gao, F., Guo, B. G., Huang, J. C., Wang, L., and Zhou, Y. J. (2013). Short-term chromium-stress-induced alterations in the maize leaf proteome. Int. J. Mol. Sci. 14, 11125-11144. doi: 10.3390/ijms 140611125

Wang, S. H., Yang, Z. M., Yang, H., Lu, B., Li, S. Q., and Lu, Y. P. (2004). Copper induced stress and antioxidative responses in roots of Brassica juncea L. Bot. Bull. Acad. Sin. 45, 203-212. Available online at: http://ejournal.sinica.edu.tw/ bbas/content/2004/3/Bot453-04.pdf

Wang, Y., Hu, H., Zhu, L. Y., and Li, X. X. (2012). Response to nickel in the proteome of the metal accumulator plant Brassica juncea. J. Plant Interact. 7, 230-237. doi: 10.1080/17429145.2011.603060

Wangeline, A. L., Burkhead, J. L., Hale, K. L., Lindblom, S. D., Terry, N., Pilon, M., et al. (2004). Over- expression of ATP sulfurylase in indian mustard: effects on tolerance and accumulation of twelve metals. J. Environ. Qual. 33, 54-60. doi: $10.2134 /$ jeq2004.5400

Wani, P. A., Khan, M. S., and Zaidi, A. (2012). "Toxic effects of heavy metal on germination and physiological processes of plants," in Toxicity of Heavy Metal to Legumes and Bioremediation, eds A. Zaidi, P. A. Wani, and M. S. Khan (Springer-Verlag Wien), 45-66.

Warne, M. S., Heemsbergen, D., Stevens, D., McLaughlin, M., Cozens, G., Whatmuff, M., et al. (2008). Modeling the toxicity of copper and zinc salts to wheat in 14 soils. Environ. Toxicol. Chem. 27, 786-792. doi: 10.1897/07-294.1

Weber, M., Trampczynska, A., and Clemens, S. (2006). Comparative transcriptome analysis of toxic metal responses in Arabidopsis thaliana and the $\mathrm{Cd}^{2+}$. hypertolerant facultative metallophyte Arabidopsis halleri. Plant Cell Environ. 29, 950-963. doi: 10.1111/j.1365-3040.2005.01479.x

Whiting, S. N., Leake, J. R., McGrath, S. P., and Baker, A. J. M. (2000). Positive responses to zinc and cadmium by roots of the hyperaccumulator Thlaspi caerulescens. New Phytol. 145, 199-210. doi: 10.1046/j.1469-8137.2000.00570.x

Wilkinson, S., Kudoyarova, G. R., Veselov, D. S., Arkhipova, T. N., and Davies, W. J. (2012). Plant hormone interactions: innovative targets for crop breeding an and management. J. Exp. Bot. 63, 3499-3509. doi: 10.1093/jxb/ers148

Williams, L. E., and Pittman, J. K. (2010). "Dissecting pathways involved in manganese homeostasis and stress in higher plants," in Cell Biology of Metals and Nutrients, Plant Cell Monographs, Vol. 17, eds R. Hell and R. R. Mendal (Berlin, Heidelberg: Springer-Verlag), 95-117.

Williams, L. E., Pittman, J. K., and Hall, J. L. (2000). Emerging mechanisms for heavy metal transport in plants. Biochim. Biophys. Acta 1465, 104-126. doi: 10.1016/S0005-2736(00)00133-4

Winkel-Shirley, B. (2002). Biosynthesis of flavonoids and effects of stress. Curr. Opin. Plant Biol. 5, 218. doi: 10.1016/S1369-5266(02)00256-X

Wong, C. K. E., and Cobbett, C. S. (2009). HMA P-Type ATPases are the major mechanism for root-to-shoot Cd translocation in Arabidopsis thaliana. New Phytol. 181, 71-78. doi: 10.1111/j.1469-8137.2008.02638.x

Wray, G. A., Hahn, M. W., Abouheif, E., Balhoff, J. P., Pizer, M., Rockman, M. V., et al. (2003). The evolution of transcriptional regulation in eukaryotes. Mol. Biol. Evol. 20, 1377-1419. doi: 10.1093/molbev/msg140

Wu, F. B., and Zhang, G. P. (2002). Genotypic variation in kernel heavy metal concentrations in barley and as affected by soil factors. J. Plant Nutr. 25, 1163-1173. doi: 10.1081/PLN-120004380

Wu, H., Chen, C., Du, J., Liu, H., Cui, Y., Zhang, Y., et al. (2012). Cooverexpression FIT with AtbHLH38 or AtbHLH39 in Arabidopsis-enhanced cadmium tolerance via increased cadmium sequestration in roots and improved iron homeostasis of shoots. Plant Physiol. 158, 790-800. doi: 10.1104/pp.111.190983
Xia, X. J., Wang, Y. J., Zhou, Y. H., Tao, Y., Mao, W. H., Shi, K., et al. (2009). Reactive oxygen species are involved in brassinosteroid-induced stress tolerance in cucumber. Plant Physiol. 150, 801-814. doi: 10.1104/pp.109.138230

Xia, X. J., Zhou, Y. H., Ding, J., Shi, K., Asami, T., Chen, Z., et al. (2011). Induction of systemic stress tolerance by brassinosteroid in Cucumis sativus. New Phytol. 191, 706-720. doi: 10.1111/j.1469-8137.2011.03745.x

Xia, Z., Sun, K., Wang, M., Wu, K., Zhang, H., and Wu, J. (2012). Overexpression of a maize sulfite oxidase gene in tobacco enhances tolerance to sulfite stress via sulfite oxidation and CAT-mediated $\mathrm{H}_{2} \mathrm{O}_{2}$ scavenging. PLoS ONE 7:e37383. doi: 10.1371/journal.pone.0037383

Xiang, C., and Oliver, D. J. (1998). Glutathione metabolic genes coordinately respond to heavy metal and jasmonic acid in Arabidopsis. Plant Cell 10, 1539-1550. doi: 10.1105/tpc.10.9.1539

Xu, J., Tian, Y. S., Peng, R. H., Xiong, A. S., Zhu, B., Jin, X. F., et al. (2009). Yeast copper-dependent transcription factor ACE1 enhanced copper stress tolerance in Arabidopsis. BMB Rep. 42, 752-757. doi: 10.5483/BMBRep.2009.42.11.752

Xu, L. L., Fan, Z. Y., Dong, Y. J., Kong, J., and Bai, X. Y. (2014). Effects of exogenous salicylic acid and nitric oxide on physiological characteristics of two peanut cultivars under cadmium stress. Biol. Plant. 59, 171-182. doi: 10.1007/s10535-014-0475-9

Yadav, S. K. (2010). Heavy metal toxicity in plants: an overview on the role of glutathione and phytochelatins in heavy metal stress tolerance of plants. South Afr. J. Bot. 76, 167-179. doi: 10.1016/j.sajb.2009.10.007

Yamaji, N., Huang, C. F., Nagao, S., Yano, M., Sato, Y., Nagamura, Y., et al. (2009). A zinc finger transcription factor ART1 regulates multiple genes implicated in aluminum tolerance in rice. Plant Cell 21, 3339-3349. doi: 10.1105/tpc.109.070771

Yang, M. J., Lin, X. Y., and Yang, X. E. (1998). Impact of Cd on growth and nutrient accumulation of different plant species. Chin. J. Appl. Ecol. 9, 89-94.

Yang, X. E., Long, X. X., and Ni, W. Z. (2002). Physiological and molecular mechanisms of heavy metal uptake by hyperaccumulating plant species. J. Plant Nutr. Fert. 8, 8-15. Available online at: http://www.ipublishing.co.in/ ijesarticles/thirteen/articles/volthree/EIJES31135.pdf

Yang, X., Feng, Y., He, Z., and Stoffell, P. J. (2005). Molecular mechanisms of heavy metal hyperaccumulation and phytoremediation. J. Trace Elem. Med. Biol. 18, 339-353. doi: 10.1016/j.jtemb.2005.02.007

Yang, Y., Qi, M., and Mei, C. (2004). Endogenous salicylic acid protects rice plants from oxidative damage caused by aging as well as biotic and abiotic stress. Plant J. 40, 909-919. doi: 10.1111/j.1365-313X.2004.02267.x

Yang, Z. M., Wang, J., Wang, S. H., and Xu, L. L. (2003). Salicylic acid-induced aluminum tolerance by modulation of citrate efflux from roots of Cassia tora $\mathrm{L}$. Planta 217, 168-174. doi: 10.1007/s00425-003-0980-0

Yin, L., Wang, S., Eltayeb, A. E., Uddin, M. I., Yamamoto, Y., Tsuji, W., et al. (2010). Overexpression of dehydroascorbate reductase, but not monodehydroascorbate reductase, confers tolerance to aluminum stress in transgenic tobacco. Planta 231, 609-621. doi: 10.1007/s00425-009-1075-3

Yuan, H. M., Xu, H. H., Liu, W. C., and Lu, Y. T. (2013). Copper regulates primary root elongation through PIN1-mediated auxin redistribution. Plant Cell Physiol. 54, 766-778. doi: 10.1093/pcp/pct030

Yuan, L., Yuan, Y., Du, J., Sun, J., and Guo, S. (2012). Effects of 24-epibrassinolide on nitrogen metabolism in cucumber seedlings under $\mathrm{Ca}\left(\mathrm{NO}_{3}\right)_{2}$ stress. Plant Physiol. Biochem. 61, 29-35. doi: 10.1016/j.plaphy.2012.09.004

Yuan, Y. X., Zhang, J., Wang, D. W., and Ling, H.-Q. (2005). AtbHLH29 of Arabidopsis thaliana is a functional ortholog of tomato FER involved in controlling iron acquisition in strategy I plants. Cell Res. 15, 613-621. doi: 10.1038/sj.cr.7290331

Yuan, Y., Wu, H., Wang, N., Li, J., Zhao, W., Du, J., et al. (2008). FIT interacts with AtbHLH38 and AtbHLH39 in regulating iron uptake gene expression for iron homeostasis in Arabidopsis. Cell Res. 18, 385-397. doi: 10.1038/cr.2008.26

Yusuf, M. A., Kumar, D., Rajwanshi, R., Strasser, R. J., Tsimilli-Michael, M., Govindjee, et al. (2010). Overexpression of c-tocopherol methyl transferase gene in transgenic Brassica juncea plants alleviates abiotic stress: physiological and chlorophyll a fluorescence measurements. Biochim. Biophys. Acta 1797, 1428-1438. doi: 10.1016/j.bbabio.2010.02.0021

Yusuf, M., Fariduddin, Q., and Ahmad, A. (2012a). 24-Epibrassinolide modulates growth, nodulation, antioxidant system, and osmolyte in tolerant and sensitive varieties of Vigna radiata under different levels of nickel: a shotgun approach. Plant Physiol. Biochem. 57, 143-153. doi: 10.1016/j.plaphy.2012.05.004 
Yusuf, M., Fariduddin, Q., Varshney, P., and Ahmad, A. (2012b). Salicylic acid minimizes nickel and/or salinity-induced toxicity in Indian mustard (Brassica juncea) through an improved antioxidant system. Environ. Sci. Pollut. Res. 19, 8-18. doi: 10.1007/s11356-011-0531-3

Zaccheo, P., Laura, C., and Valeria, D. M. P. (2006). Ammonium nutrition as a strategy for cadmium metabolisation in the rhizosphere of sunflower. Plant Soil 283, 43-56. doi: 10.1007/s11104-005-4791-x

Zhang, A., Zhang, J., Zhang, J., Ye, N., Zhang, H., Tan, M., et al. (2011). Nitric oxide mediates brassinosteroid-induced ABA biosynthesis involved in oxidative stress tolerance in maize leaves. Plant Cell Physiol. 52, 181-192. doi: $10.1093 / \mathrm{pcp} / \mathrm{pcq} 187$

Zhang, G., Chen, M., Li, L., Xu, Z., Chen, X., Guo, J., et al. (2009a). Overexpression of the soybean GmERF3 gene, an AP2/ERF type transcription factor for increased tolerances to salt, drought, and diseases in transgenic tobacco. J. Exp. Bot. 60, 3781-3796. doi: 10.1093/jxb/erp214

Zhang, H., Lian, C., and Shen, Z. (2009b). Proteomic identification of small, copper-responsive proteins in germinating embryos of Oryza sativa. Ann. Bot. 103, 923-930. doi: 10.1093/aob/mcp012

Zhang, Y., Li, J., Yu, F., Cong, L., Wang, L., Burkard, G., et al. (2006). Cloning and expression analysis of SKn-type dehydrin gene from bean in response to heavy metal. Mol. Biotechnol. 32, 205-217. doi: 10.1385/MB:32:3:205

Zhang, Y., Yu, Z., Fu, X., and Liang, C. (2002). Noc3p, a bHLH protein, plays an integral role in the initiation of DNA replication in budding yeast. Cell 109, 849-860. doi: 10.1016/S0092-8674(02)00805-X

Zhang, Z. C., Chen, B. X., and Qiu, B. S. (2010). Phytochelatin synthesis plays a similar role in shoots of the cadmium hyperaccumulator Sedum alfredii as in non-resistant plants. Plant Cell Environ. 33, 1248-1255. doi: 10.1111/j.13653040.2010.02144.X

Zhao, L., Sun, Y. L., Cui, S. X., Chen, M., Yang, H. M., Liu, H. M., et al. (2011). Cdinduced changes in leaf proteome of the hyperaccumulator plant Phytolacca americana. Chemosphere 85, 56-66. doi: 10.1016/j.chemosphere.2011.06.029

Zhao, Z. Q., Zhu, Y. G., Li, H. Y., Smith, S. E., and Smith, F. A. (2004). Effects of forms and rates of potassium fertilizers on cadmium uptake by two cultivars of spring wheat (Triticum aestivum L.). Environ. Int. 29, 973-978. doi: 10.1016/S0160-4120(03)00081-3

Zheng, X. W., Qiu, R. L., Ying, R. R., Tang, Y. T., Tang, L., and Fang, X. H. (2011). The differentially-expressed proteome in $\mathrm{Zn} / \mathrm{Cd}$ hyperaccumulator Arabis paniculata Franch. in response to $\mathrm{Zn}$ and Cd. Chemosphere 82, 321-328. doi: 10.1016/j.chemosphere.2010.10.030

Zhenyan, H. E., Jiangchuan, L. I., Zhang, H., and Ma, M. I. (2005). Different effects of calcium and lanthanum on the expression of phytochelatin synthase gene and cadmium absorption in Lactuca sativa. Plant Sci. 168, 309-318. doi: 10.1016/j.plantsci.2004.07.001

Zhigang, A., Cuijie, L., Yuangang, Z., Yejie, D., Wachter, A., and Gromes, R. (2006). Expression of BjMT2, a metallothionein 2 from Brassica juncea, increases copper and cadmium tolerance in Escherichia coli and Arabidopsis thaliana, but inhibits root elongation in Arabidopsis thaliana seedlings. J. Exp. Bot. 57, 3575-3582. doi: 10.1093/jxb/erl102

Zhou, J., and Goldsbrough, P. B. (1994). Functional homologs of fungal metallothionein genes from Arabidopsis. Plant Cell 6, 875-884. doi: $10.1105 /$ tpc.6.6.875

Zhou, Z. S., Guo, K., Elbaz, A. A., and Yang, Z. M. (2009). Salicylic acid alleviates mercury toxicity by preventing oxidative stress in roots of Medicago sativa. Environ. Exp. Bot. 65, 27-34. doi: 10.1016/j.envexpbot.2008.06.001

Zhu, E., Liu, D., Li, J. G., Li, T. Q., Yang, X. E., He, Z. L., et al. (2011). Effect of nitrogen fertilizer on growth and cadmium accumulation in Sedum alfredii Hance. J. Plant Nutr. 34, 115-126. doi: 10.1080/01904167.2011.531363

Zhu, X. F., Jiang, T., Wang, Z. W., Lei, G. J., Shi, Y. Z., Li, G. X., et al. (2012). Gibberellic acid alleviates cadmium toxicity by reducing nitric oxide accumulation and expression of IRT1 in Arabidopsis thaliana. J. Hazard. Mater. 239-240, 302-307. doi: 10.1016/j.jhazmat.2012.08.077

Zimeri, A. M., Dhankher, O. P., McCaig, B., and Meagher, R. B. (2005). The plant MT1 metallothioneins are stabilized by binding cadmium and are required for cadmium tolerance and accumulation. Plant Mol. Biol. 58, 839-855. doi: 10.1007/s11103-005-8268-3

Zobel, R. W., Kinraide, T. B., and Baligar, V. C. (2007). Fine root diameters can change in response to changes in nutrient concentrations. Plant Soil 297, 243-254. doi: 10.1007/s11104-007-9341-2

Zornoza, P., Sánchez-Pardo, B., and Carpena, R. R. O. (2010). Interaction and accumulation of manganese and cadmium in the manganese accumulator Lupinus albus. J. Plant Physiol. 167, 1027-1032. doi: 10.1016/j.jplph.2010.02.011

Conflict of Interest Statement: The authors declare that the research was conducted in the absence of any commercial or financial relationships that could be construed as a potential conflict of interest.

Copyright (C) 2016 Singh, Parihar, Singh, Singh and Prasad. This is an open-access article distributed under the terms of the Creative Commons Attribution License (CC $B Y)$. The use, distribution or reproduction in other forums is permitted, provided the original author(s) or licensor are credited and that the original publication in this journal is cited, in accordance with accepted academic practice. No use, distribution or reproduction is permitted which does not comply with these terms. 